\title{
Adjuvant chemotherapy for resected early-stage non-small cell lung cancer (Review)
}

Burdett S, Pignon JP, Tierney J, Tribodet H, Stewart L, Le Pechoux C, Aupérin A, Le Chevalier T, Stephens RJ, Arriagada R, Higgins JPT, Johnson DH, Van Meerbeeck J, Parmar MKB, Souhami RL, Bergman B, Douillard JY, Dunant A, Endo C, Girling D, Kato H, Keller SM, Kimura H, Knuuttila A, Kodama K, Komaki R, Kris MG, Lad T, Mineo T, Piantadosi S, Rosell R, Scagliotti G, Seymour LK, Shepherd FA, Sylvester R, Tada H, Tanaka F, Torri V, Waller D, Liang Y, for the Non-Small Cell Lung Cancer Collaborative Group

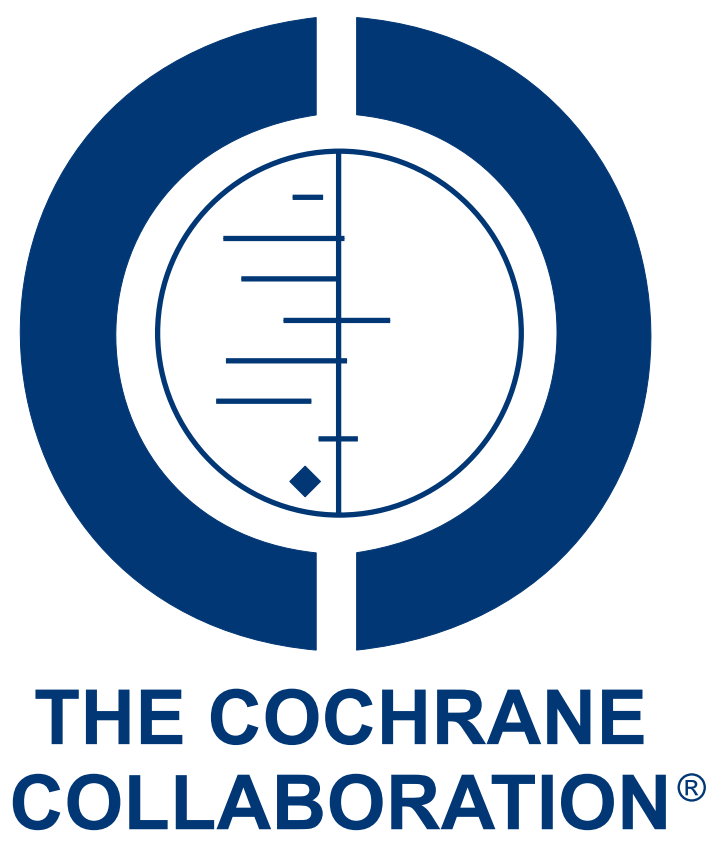

This is a reprint of a Cochrane review, prepared and maintained by The Cochrane Collaboration and published in The Cochrane Library 2015, Issue 3

http://www.thecochranelibrary.com

\section{WILEY}

Adjuvant chemotherapy for resected early-stage non-small cell lung cancer (Review) 
TABLE OF CONTENTS

HEADER

ABSTRACT

PLAIN LANGUAGE SUMMARY . . . . . . . . . . . . . . . . . . . . . . . . . . . . . . . . . . .

BACKGROUND . . . . . . . . . . . . . . . . . . . . . . . . . . . . . . . . . . . . . 4

OBJECTIVES . . . . . . . . . . . . . . . . . . . . . . . . . . . . . . . . . . . . . 44

METHODS . . . . . . . . . . . . . . . . . . . . . . . . . . . . . . . . . . . . . . 5

Figure 1. . . . . . . . . . . . . . . . . . . . . . . . . . . . . . . . . . . . . .

RESULTS . . . . . . . . . . . . . . . . . . . . . . . . . . . . . . . . 9

Figure 2. . . . . . . . . . . . . . . . . . . . . . . . . . . . . . . . . . . . . . 10

Figure 3. . . . . . . . . . . . . . . . . . . . . . . . . . . . . . . . . . . . . . 11

Figure 4. . . . . . . . . . . . . . . . . . . . . . . . . . . . . . . . . . . . . . 12

Figure 5. . . . . . . . . . . . . . . . . . . . . . . . . . . . . . . . . . . . . . 13

Figure 6. . . . . . . . . . . . . . . . . . . . . . . . . . . . . . . . . . . . . . 14

Figure $7 . \quad$. . . . . . . . . . . . . . . . . . . . . . . . . . . . . . . . . . . . . 15

Figure 8. . . . . . . . . . . . . . . . . . . . . . . . . . . . . . . . . 16

Figure 9. . . . . . . . . . . . . . . . . . . . . . . . . . . . . . . . . . . 17

DISCUSSION . . . . . . . . . . . . . . . . . . . . . . . . . . . . . . . . . . . . . 17

AUTHORS' CONCLUSIONS . . . . . . . . . . . . . . . . . . . . . . . . . . . . . . . . . . . . . . . .

ACKNOWLEDGEMENTS . . . . . . . . . . . . . . . . . . . . . . . . . . . . . . . . . . . . . . .

REFERENCES . . . . . . . . . . . . . . . . . . . . . . . . . . . . . . . . . . . . . 19

CHARACTERISTICS OF STUDIES . . . . . . . . . . . . . . . . . . . . . . . . . . . . . . . . . . . . . . . .

DATA AND ANALYSES . . . . . . . . . . . . . . . . . . . . . . . . . . . . . . . . . . . . 65

Analysis 1.1. Comparison 1 Surgery versus surgery + adjuvant chemotherapy, Outcome 1 Survival. . . . . . . . 66

Analysis 2.1. Comparison 2 Surgery + radiotherapy versus surgery + radiotherapy + adjuvant chemotherapy, Outcome 1 Survival. . . . . . . . . . . . . . . . . . . . . . . . . . . . . . . . . . . . 68

ADDITIONAL TABLES . . . . . . . . . . . . . . . . . . . . . . . . . . . . . . . . . . $\quad 69$

APPENDICES . . . . . . . . . . . . . . . . . . . . . . . . . . . . . . . . . . . . . 71

CONTRIBUTIONS OF AUTHORS . . . . . . . . . . . . . . . . . . . . . . . . . . . . . . . . . . . . 72

DECLARATIONS OF INTEREST . . . . . . . . . . . . . . . . . . . . . . . . . . . . . . . . . . 73

SOURCES OF SUPPORT . . . . . . . . . . . . . . . . . . . . . . . . . . . . . . . . . . 73

NOTES . . . . . . . . . . . . . . . . . . . . . . . . . . . . . . . . . . . . . . . . 73

INDEX TERMS . . . . . . . . . . . . . . . . . . . . . . . . . . . . . . . . . . . . 73 


\section{[Intervention Review]}

\section{Adjuvant chemotherapy for resected early-stage non-small cell lung cancer}

Sarah Burdett ${ }^{1}$, Jean Pierre Pignon ${ }^{2}$, Jayne Tierney ${ }^{1}$, Helene Tribodet $^{2}$, Lesley Stewart ${ }^{3}$, Cecile Le Pechoux ${ }^{4}$, Anne Aupérin ${ }^{2}$, Thierry Le Chevalier $^{5}$, Richard J Stephens ${ }^{6}$, Rodrigo Arriagada ${ }^{7}$, Julian PT Higgins ${ }^{8}$, David H Johnson ${ }^{9}$, Jan Van Meerbeeck ${ }^{10}$, Mahesh KB Parmar $^{6}$, Robert L Souhami ${ }^{11}$, Bengt Bergman ${ }^{12}$, Jean-Yves Douillard ${ }^{13}$, Ariane Dunant ${ }^{2}$, Chiaki Endo ${ }^{14}$, David Girling ${ }^{6}$, Harubumi Kato $^{15}$, Steven M Keller ${ }^{16}$, Hideki Kimura ${ }^{17}$, Aija Knuuttila ${ }^{18}$, Ken Kodama ${ }^{19}$, Ritsuko Komaki ${ }^{20}$, Mark G Kris ${ }^{21}$, Thomas Lad ${ }^{22}$, Tommaso Mineo ${ }^{23}$, Steven Piantadosi ${ }^{24}$, Rafael Rosell ${ }^{25}$, Giorgio Scagliotti ${ }^{26}$, Lesley K Seymour ${ }^{27}$, Frances A Shepherd ${ }^{28}$, Richard Sylvester ${ }^{29}$, Hirohito Tada ${ }^{30}$, Fumihiro Tanaka ${ }^{31}$, Valter Torri ${ }^{32}$, David Waller ${ }^{33}$, Ying Liang ${ }^{34}$, for the Non-Small Cell Lung Cancer Collaborative Group ${ }^{1}$

${ }^{1}$ Meta-analysis Group, MRC Clinical Trials Unit at UCL, London, UK. ${ }^{2}$ Plateforme LNCC de Méta-analyse en Oncologie et Service de Biostatistique et d'Epidémiologie, Gustave Roussy Cancer Campus, Villejuif, France. ${ }^{3}$ Centre for Reviews and Dissemination, University of York, York, UK. ${ }^{4}$ Département de Radiothérapie, Gustave Roussy Cancer Campus, Villejuif, France. ${ }^{5}$ Département de Médecine, Gustave Roussy Cancer Campus, Villejuif, France. ${ }^{6}$ Cancer Division, MRC Clinical Trials Unit at UCL, London, UK. ${ }^{7}$ Karolinska Institutet, Stockholm, Sweden. ${ }^{8}$ School of Social and Community Medicine, University of Bristol, Bristol, UK. ${ }^{9}$ Department of Medicine, University of Texas Southwestern Medical Center, Dallas, Texas, USA. ${ }^{10}$ University Hospital, Ghent, Belgium. ${ }^{11}$ Cancer Research UK, London, UK. ${ }^{12}$ Sahlgrenska Academy, Gothenberg, Sweden. ${ }^{13}$ Integrated Centers of Oncology R Gauducheau, St Herblain, France. ${ }^{14}$ Institute of Development, Aging and Cancer, Tohoku University, Sendai, Japan. ${ }^{15}$ Tokyo Medical University, Tokyo, Japan. ${ }^{16}$ Montefi ore Medical Center, New York, USA. ${ }^{17}$ Chiba Cancer Center, Chiba City, Japan. ${ }^{18}$ Pulmonary Department, Helsinki University Central Hospital, Helsinki, Finland. ${ }^{19}$ Osaka Medical Center for Cancer and Cardiovascular Diseases, Osaka, Japan. ${ }^{20}$ University of Texas MD Anderson Cancer Center, Houston, Texas, USA. ${ }^{21}$ Memorial Sloan-Kettering Cancer Center, New York, USA. ${ }^{22}$ Cook County Hospital, Chicago, Illinois, USA. ${ }^{23}$ Policlinico Tor Vergata, University, Roma, Italy. ${ }^{24}$ Cedars Sinai Medical Centre, Samuel Oschin Comprehensive Cancer Institute, Los Angeles, California, USA. ${ }^{25}$ Catalan Institute of Oncology, Hospital Germans Trias i Pujol, Barcelona, Spain. ${ }^{26}$ S. Luigi Hospital, Turin, Italy. ${ }^{27}$ Queen's University, NCIC Clinical Trials Group, Kingston, Canada. ${ }^{28}$ Princess Margaret Cancer Centre, Toronto, Canada. ${ }^{29}$ Data Center, European Organisation for Research and Treatment of Cancer, Brussels, Belgium. ${ }^{30}$ Suita Saiseikai Hospital, Suita, Japan. ${ }^{31}$ Chest Surgery (Second Department of Surgery), University of Occupational and Environmental Health, Kitakyusyu, Japan. ${ }^{32}$ Laboratorio di Epidemiologia Clinica, Mario Negri Institute, Milano, Italy. ${ }^{33}$ Glenfield Hospital, Leicester, UK. ${ }^{34}$ Sun Yat-Sen University Cancer Center, Guangzhou, China

Contact address: Sarah Burdett, Meta-analysis Group, MRC Clinical Trials Unit at UCL, Aviation House, 125 Kingsway, London, WC2B 6NH, UK. sarah.burdett@ucl.ac.uk.

Editorial group: Cochrane Lung Cancer Group.

Publication status and date: New, published in Issue 3, 2015.

Review content assessed as up-to-date: 31 December 2013.

Citation: Burdett S, Pignon JP, Tierney J, Tribodet H, Stewart L, Le Pechoux C, Aupérin A, Le Chevalier T, Stephens RJ, Arriagada R, Higgins JPT, Johnson DH, Van Meerbeeck J, Parmar MKB, Souhami RL, Bergman B, Douillard JY, Dunant A, Endo C, Girling D, Kato H, Keller SM, Kimura H, Knuuttila A, Kodama K, Komaki R, Kris MG, Lad T, Mineo T, Piantadosi S, Rosell R, Scagliotti G, Seymour LK, Shepherd FA, Sylvester R, Tada H, Tanaka F, Torri V, Waller D, Liang Y, for the Non-Small Cell Lung Cancer Collaborative Group. Adjuvant chemotherapy for resected early-stage non-small cell lung cancer. Cochrane Database of Systematic Reviews 2015, Issue 3. Art. No.: CD011430. DOI: 10.1002/14651858.CD011430.

Copyright (C) 2015 The Cochrane Collaboration. Published by John Wiley \& Sons, Ltd.

\section{A B S T R A C T}

Adjuvant chemotherapy for resected early-stage non-small cell lung cancer (Review)

Copyright (๑) 2015 The Cochrane Collaboration. Published by John Wiley \& Sons, Ltd. 


\section{Background}

To evaluate the effects of administering chemotherapy following surgery, or following surgery plus radiotherapy (known as adjuvant chemotherapy) in patients with early stage non-small cell lung cancer (NSCLC),we performed two systematic reviews and meta-analyses of all randomised controlled trials using individual participant data. Results were first published in The Lancet in 2010.

\section{Objectives}

To compare, in terms of overall survival, time to locoregional recurrence, time to distant recurrence and recurrence-free survival:

A. Surgery versus surgery plus adjuvant chemotherapy

B. Surgery plus radiotherapy versus surgery plus radiotherapy plus adjuvant chemotherapy

in patients with histologically diagnosed early stage NSCLC.

(2)To investigate whether or not predefined patient subgroups benefit more or less from cisplatin-based chemotherapy in terms of survival.

\section{Search methods}

We supplemented MEDLINE and CANCERLIT searches (1995 to December 2013) with information from trial registers, handsearching relevant meeting proceedings and by discussion with trialists and organisations.

\section{Selection criteria}

We included trials of a) surgery versus surgery plus adjuvant chemotherapy; and b) surgery plus radiotherapy versus surgery plus radiotherapy plus adjuvant chemotherapy, provided that they randomised NSCLC patients using a method which precluded prior knowledge of treatment assignment.

\section{Data collection and analysis}

We carried out a quantitative meta-analysis using updated information from individual participants from all randomised trials. Data from all patients were sought from those responsible for the trial. We obtained updated individual participant data (IPD) on survival, and date of last follow-up, as well as details of treatment allocated, date of randomisation, age, sex, histological cell type, stage, and performance status. To avoid potential bias, we requested information for all randomised patients, including those excluded from the investigators' original analyses. We conducted all analyses on intention-to-treat on the endpoint of survival. For trials using cisplatinbased regimens, we carried out subgroup analyses by age, sex, histological cell type, tumour stage, and performance status.

\section{Main results}

We identified 35 trials evaluating surgery plus adjuvant chemotherapy versus surgery alone. IPD were available for 26 of these trials and our analyses are based on 8447 participants (3323 deaths) in 34 trial comparisons. There was clear evidence of a benefit of adding chemotherapy after surgery (hazard ratio $(H R)=0.86,95 \%$ confidence interval $(\mathrm{CI})=0.81$ to $0.92, \mathrm{p}<0.0001$ ), with an absolute increase in survival of $4 \%$ at five years.

We identified 15 trials evaluating surgery plus radiotherapy plus chemotherapy versus surgery plus radiotherapy alone. IPD were available for 12 of these trials and our analyses are based on 2660 participants (1909 deaths) in 13 trial comparisons. There was also evidence of a benefit of adding chemotherapy to surgery plus radiotherapy $(\mathrm{HR}=0.88,95 \% \mathrm{CI}=0.81$ to $0.97, \mathrm{p}=0.009)$. This represents an absolute improvement in survival of $4 \%$ at five years.

For both meta-analyses, we found similar benefits for recurrence outcomes and there was little variation in effect according to the type of chemotherapy, other trial characteristics or patient subgroup.

We did not undertake analysis of the effects of adjuvant chemotherapy on quality of life and adverse events. Quality of life information was not routinely collected during the trials, but where toxicity was assessed and mentioned in the publications, it was thought to be manageable. We considered the risk of bias in the included trials to be low.

\section{Authors' conclusions}

Results from 47 trial comparisons and 11,107 patients demonstrate the clear benefit of adjuvant chemotherapy for these patients, irrespective of whether chemotherapy was given in addition to surgery or surgery plus radiotherapy. This is the most up-to-date and complete systematic review and individual participant data (IPD) meta-analysis that has been carried out. 


\section{PLAIN LANGUAGE SUMMARY}

\section{Chemotherapy after surgery for early stage non-small cell lung cancer}

\section{Review question}

Do patients with non-small cell lung cancer live longer if they are given chemotherapy after surgery?

\section{Background}

Non-small cell lung cancer is the most common type of lung cancer. If the tumour is early stage, not too big and has not spread to other parts of the body, doctors usually operate to remove it. At the same time, they will also remove a bit of the lung, or the entire lung that has the tumour. They may also give radiotherapy (treatment with $\mathrm{x}$-rays) after the operation, aiming to kill any remaining cancer cells. They may also give chemotherapy (drug treatment) after surgery to lower the risk of the cancer coming back. This treatment is called adjuvant chemotherapy.

In 1995, we did a systematic review and meta-analysis of individual participant data looking at adjuvant chemotherapy and surgery (with or without radiotherapy). It brought together information from all patients who took part in similar trials. These trials compared what happened to people with non-small cell lung cancer who were given chemotherapy after surgery (with or without radiotherapy) with those who had surgery without chemotherapy (with or without radiotherapy). We found that it was not clear whether chemotherapy helped patients with non-small cell lung cancer live longer.

Since this study was completed, many new trials have been done. Therefore, we carried out a new systematic review and meta-analysis of individual participant data that included all trials, old and new. This study aimed to find out if giving chemotherapy after surgery (with or without radiotherapy) can a) help patients live longer, b) stop the cancer coming back (recurrence), and c) stop the cancer spreading to other parts of the body (metastases).

We carried out two studies called meta-analyses that included patients with non-small cell lung cancer that took part in randomised controlled trials comparing:

a) surgery versus surgery plus adjuvant chemotherapy; and

b) surgery plus radiotherapy versus surgery plus radiotherapy plus adjuvant chemotherapy.

Results were first published in the Lancet in 2010.

\section{Study characteristics}

We searched for relevant trials up to December 2013. The studies brought together trial data from all over the world with 26 trials (34 trial comparisons) and 8447 patients in the first meta-analysis (surgery versus surgery plus adjuvant chemotherapy); and 12 trials (13 trial comparisons) and 2660 patients in the second meta-analysis (surgery plus radiotherapy versus surgery plus radiotherapy plus adjuvant chemotherapy). Trials were carried out between 1979 and 2003.

\section{Key results}

Results found that people with non-small cell lung cancer that had surgery followed by chemotherapy (with or without radiotherapy), lived longer than those who had surgery without chemotherapy (with or without radiotherapy).

After five years, 64 out of every 100 patients who were given chemotherapy after surgery were alive compared to 60 patients out of every 100 who just had surgery. For those who also received radiotherapy, after five years, 33 out of every 100 patients who received chemotherapy, surgery and radiotherapy were alive compared to 29 out of every 100 patients who received surgery and radiotherapy.

Quality of life information was not routinely collected during the trials, but where toxicity was assessed and mentioned in the publications, it was thought to be manageable.

Adjuvant chemotherapy for resected early-stage non-small cell lung cancer (Review)

Copyright @ 2015 The Cochrane Collaboration. Published by John Wiley \& Sons, Ltd. 
In both studies, there was little variation in the effect of chemotherapy according to the type of chemotherapy given, other trial characteristics, or by the type of patient included in the trial.

\section{Quality of evidence}

These systematic reviews and meta-analyses use individual participant data, which is considered the gold standard of this type of review. We included all eligible trials if possible, no matter what language they were published in or whether they were published or not. The first meta-analysis (surgery versus surgery plus adjuvant chemotherapy) included $92 \%$ of all patients in eligible trials and the second meta-analysis (surgery plus radiotherapy versus surgery plus radiotherapy plus adjuvant chemotherapy) included $86 \%$ of all patients in eligible trials.

We are confident that further research is unlikely to change the findings. The studies were well designed and conducted, address the review question, and the effects are consistent across trials. The impact of any data we have not been able to include in our analyses is small.

\section{B A C K G R O U N D}

\section{Description of the condition}

Worldwide, around 1.5 million new cases of lung cancer are diagnosed annually (Parkin 2005), and approximately $85 \%$ of such cases are non-small cell lung cancer (NSCLC).(American Cancer Society 2007). Although surgery is regarded as optimal treatment, only $20 \%$ to $25 \%$ of tumours are suitable for potentially curative resection (Datta 2003), therefore other treatments are also used. Our previous individual participant data (IPD) meta-analyses (NSCLC Collaborative Group 1995), gave evidence that cisplatin-based chemotherapy after surgery might prolong survival (hazard ratio $(\mathrm{HR})]=0.87,95 \%$ confidence interval $(\mathrm{CI})=0.74$ to $1.02, \mathrm{p}=0.08$ ). With fewer trials and patients, the value of chemotherapy following surgery plus postoperative radiotherapy was less clear (NSCLC Collaborative Group 1995). Recent meta-analyses (Berghmans 2005; Bria 2005; Hamada 2005; Hotta 2004; Pignon 2008; Sedrakyan 2004) showing significant survival benefits with adjuvant chemotherapy, that is chemotherapy given after surgery, have included a variety of trials and patients (Table 1).

\section{Description of the intervention}

This review concentrated on randomised controlled trials that had tested surgery alone with drug treatment (chemotherapy) with or with out radiotherapy after surgery. These trials mainly used cisplatin-based chemotherapy, this is commonly used for treatment of lung cancer as well as other cancers. Some trials, mainly those that took place in Asia, used UFT (also called tegafur/uracil) chemotherapy.

\section{How the intervention might work}

If the tumour is early stage, for example, not too big and has not spread to other parts of the body, doctors usually operate to remove it. At the same time, they will also remove a bit of the lung, or the entire lung that has the tumour. They may also give radiotherapy after the operation, aiming to kill any remaining cancer cells. They may also give chemotherapy after surgery to lower the risk of the cancer coming back. This treatment is called adjuvant chemotherapy.

\section{Why it is important to do this review}

The aim of this review was to assess more reliably the effects of adjuvant chemotherapy, with or without postoperative radiotherapy, in two new comprehensive IPD meta-analyses. Contrary to our previous meta-analyses, the present study is restricted to patients with early stage disease.

Results of these two meta-analyses were first published in The Lancet in 2010 (NSCLC Meta-analysis Collaborative Group 2010).

\section{O B J E C T IVES}

To compare, in terms of overall survival, time to locoregional recurrence, time to distant recurrence and recurrence-free survival:

A. Surgery versus surgery plus adjuvant chemotherapy

B. Surgery plus radiotherapy versus surgery plus radiotherapy plus adjuvant chemotherapy 
in patients with histologically diagnosed early stage non-small cell lung cancer.

(2)To investigate whether or not predefined patient subgroups benefit more or less from cisplatin-based chemotherapy in terms of survival.

Part A was carried out by the MRC CTU at UCL in London, UK and Part B was carried out by the Institute Gustave Roussy, Villejuif, France.

\section{METHODS}

\section{Criteria for considering studies for this review}

\section{Types of studies}

To be included, both published and unpublished completed trials had to be properly randomised using established methods (not quasi-randomised). Trials could not have been confounded by additional therapeutic differences between the two arms and must have commenced randomisation on or after 1 January 1965. Trials should have aimed to include patients who had undergone a potentially curative resection and not received previous chemotherapy. For the first meta-analysis, trials should have compared surgery versus surgery plus adjuvant chemotherapy. For the second, trials should have compared surgery plus radiotherapy versus surgery plus radiotherapy plus adjuvant chemotherapy. We excluded trials using long-term alkylating agents for more than a year because these are no longer used to treat non-small cell lung cancer (NSCLC), and have been shown to be harmful (NSCLC Collaborative Group 1995).

\section{Types of participants}

Eligible trials included individuals with histologically confirmed NSCLC who had undergone a potentially curative resection. We included individual participant data from all randomised patients in the meta-analyses, and where possible obtained data for individuals who had been excluded from the original trial analyses. We excluded from the meta-analyses patients with small cell lung cancer that were included in early trials that randomised all types of lung cancer.

\section{Types of interventions}

We classified trials as belonging to one of the following categories of chemotherapy.

- Surgery versus surgery plus adjuvant chemotherapy $\circ$ platinum plus vinca alkaloid/etoposide $\circ$ platinum plus vinorelbine
- platinum plus taxane

o other platinum regimens

- platinum plus vinca alkaloid plus tegafur and uracil/ tegafur

- tegafur and uracil/tegafur plus other agent

$\circ$ tegafur and uracil/tegafur

- Surgery plus radiotherapy versus surgery plus radiotherapy plus adjuvant chemotherapy

- platinum plus vinca alkaloid/etoposide

$\circ$ platinum plus vinorelbine

$\circ$ other platinum regimens

$\circ$ antimetabolic agent only

\section{Types of outcome measures}

\section{Primary outcomes}

The primary outcome was overall survival, defined as the time from randomisation until death by any cause. Living patients were censored on the date of last follow-up

\section{Secondary outcomes}

Recurrence-free survival was defined as the time from randomisation until first recurrence, or death by any cause. Patients alive without disease were censored on the date of last follow-up. To avoid bias from under-reporting of subsequent events, time to locoregional recurrence was defined as the time from randomisation until first locoregional recurrence, with patients experiencing earlier distant recurrences being censored at the time of distant recurrence. Similarly, for time to distant recurrence, patients experiencing earlier locoregional recurrences were censored on that date. Patients who died without recurrence were censored on date of death. Data on quality of life and adverse events were not routinely collected in the trials and therefore could not be analysed in this review.

\section{Search methods for identification of studies}

To limit publication bias, we included published and unpublished trials with no restriction based on language. We carried out searches of MEDLINE and CANCERLIT from 1995 (using The Cochrane Collaboration's optimal strategy (Lefebvre 2001; Lefebvre 2008). We supplemented trial registers by handsearches of conference proceedings and reference lists of trial publications and review articles. We asked our collaborators if they knew of additional trials. We carried out initial searches in 2003 and regularly updated these; we carried out the most recent searches in December 2013. 


\section{Electronic searches}

We modified The Cochrane Collaboration's optimum search strategy for retrieving randomised controlled trials (RCTs) from MEDLINE (Appendix 1) to specifically retrieve RCTs of chemotherapy for NSCLC and used this search strategy to search MEDLINE and CANCERLIT (1995 to 2013).

In addition, we searched the following electronic bibliographic databases.

- The Cochrane Central Register of Controlled Trials

(CENTRAL) (1995 to 2013)

- Proceedings of American Society for Clinical Oncology

(ASCO) (1995 to 2013)

We used the following trial registers to supplement searches of electronic databases with trials that were not (yet) published or were still recruiting patients.

- United Kingdom Coordinating Committee on Cancer

Research (UKCCCR) Trials Register

- ClinicalTrials.gov

- Physicians Data Query Protocols (open and closed)

- Current Controlled Trials 'metaRegister' of controlled trials

\section{Searching other resources}

\section{Handsearches}

We carried out the following handsearches to identify trials that may have only been reported as abstracts or that might have been missed in the searches described above.

- Proceedings of the American Society for Clinical Oncology (ASCO) 1993 to 1994

- Proceedings of the International Association for the Study of Lung Cancer (IASLC) World Lung Cancer Conference 1997 to 2013

- Proceedings of the European Society of Medical Oncology (ESMO) 1996 to 2013

- Proceedings of the European Cancer Conference Organization (ECCO) 1995 to 2013

\section{Reference lists}

We searched bibliographies of all identified trials and review articles.

\section{Correspondence}

We asked all participating trialists to review and supplement a provisional list of trials.

\section{Data collection and analysis}

\section{Selection of studies}

Four Members of the Project Management Group (SB, AA, JPP, LA) checked all titles and abstracts, identified by both electronic searching and handsearching of conference proceedings, and obtained the full publications for those thought to be potentially relevant. We sought individual participant data (IPD) from trial authors, including updated follow-up, where available.

\section{Data extraction and management}

We sought individual participant data for all eligible trials. For the 15 trials originally included in the 1995 analysis of the NSCLC Collaborative Group, we only sought updated follow-up. For new trials, we sought data on age, sex, extent of resection, pathological tumour stage, histology, performance status, treatment arm, date of randomisation, recurrence, survival and follow-up for all patients randomised.

We used standard checks to identify missing data. We verified the data, for example, by checking the order of the dates, and assessed data validity and consistency. To assess randomisation integrity, we checked patterns of treatment allocation and balance of baseline characteristics by treatment arm. We checked follow-up of surviving patients to ensure that it was balanced by treatment arm and up-to-date. We resolved any queries and each trial investigator or statistician verified the final database.

\section{Project co-ordination}

Two teams co-ordinated the project management. Each team collected and checked data and analysed results for their comparison as follows:

- Team A: surgery versus surgery plus adjuvant chemotherapy (MRC CTU at UCL, London, UK);

- Team B: surgery plus radiotherapy versus surgery plus radiotherapy plus adjuvant chemotherapy (Institut Gustave Roussy, Villejuif, France).

\section{Assessment of risk of bias in included studies}

We assessed the included studies using The Cochrane Collaboration's 'Risk of bias' tool outlined in Table $8.5 \mathrm{c}$ of the Cochrane Handbook for Systematic Reviews of Interventions (Higgins 2011) and these studies were checked by a second review author. We considered adequate sequence generation and allocation concealment to be most important and therefore a judgement of low risk was desirable for these domains for all trials. Blinding was not appropriate due to the nature of the treatments and any issues surrounding the reporting of incomplete outcome data, selective 
outcome reporting or attrition bias were overcome by the collection of IPD.

\section{Measures of treatment effect}

Unless otherwise stated, we prespecified all analyses in the protocols, and carried out on an intention-to-treat analysis. For each outcome, we used the logrank expected number of events and variance to calculate individual trial hazard ratios (HRs), which were pooled across trials using the fixed-effect model. We presented overall survival using simple (non-stratified) Kaplan-Meier curves. We computed the median follow-up for all patients using the reverse Kaplan-Meier method (Schemper 1996).

To explore any impact of trial characteristics on the effect of adjuvant chemotherapy on overall survival, we calculated pooled HRs for each prespecified trial group and used $\mathrm{Chi}^{2}$ tests for interaction to investigate differences in the treatment effect across these trial groups.

We calculated absolute differences in overall survival at five years using overall HRs and control group survival. If we identified a difference in effect by trial group or patient subgroup, we used HRs and control group survival for the relevant groups to calculate absolute differences; otherwise we used the overall HR.

As two trials compared two adjuvant chemotherapy regimens with one control arm, we compared each treatment arm with the control arm and analysed these as separate trial comparisons in different chemotherapy categories (A22 WJSG $2(1+3)$; A25 ACTLC4a; A29 WJSG2 (2+3); A33 ACTLC4b). To avoid double-counting the control arms in the overall and subgroup analyses, however, we combined the treatment arms and compared them with the relevant control arm. Because of this, there are no overall totals in Figure 1. For other trials that belonged in different chemotherapy categories (A06 ALPI1; B06 ALPI2), different meta-analyses or both (A07 IALT1; A08 BLT1; A12 IALT2; A13 BLT2; A18 BLT3; A20 OLCSG1c; A27 OLCSG1b; A28 OLCSG1a; B07 IALT3; B08 BLT4; B10 IALT4; B13 OLCSG1d) we compared relevant patients from the treatment arm with the corresponding control arm patients, and analysed them as separate trial comparisons. This gives a greater number of trial comparisons than there are trials. 
Figure I. For all chemotherapy groups, HR 0.86 ( 0.8 I to 92$) ; p<0.000$ I Forest plot of comparison: I surgery versus surgery + chemotherapy, outcome: I.I survival.

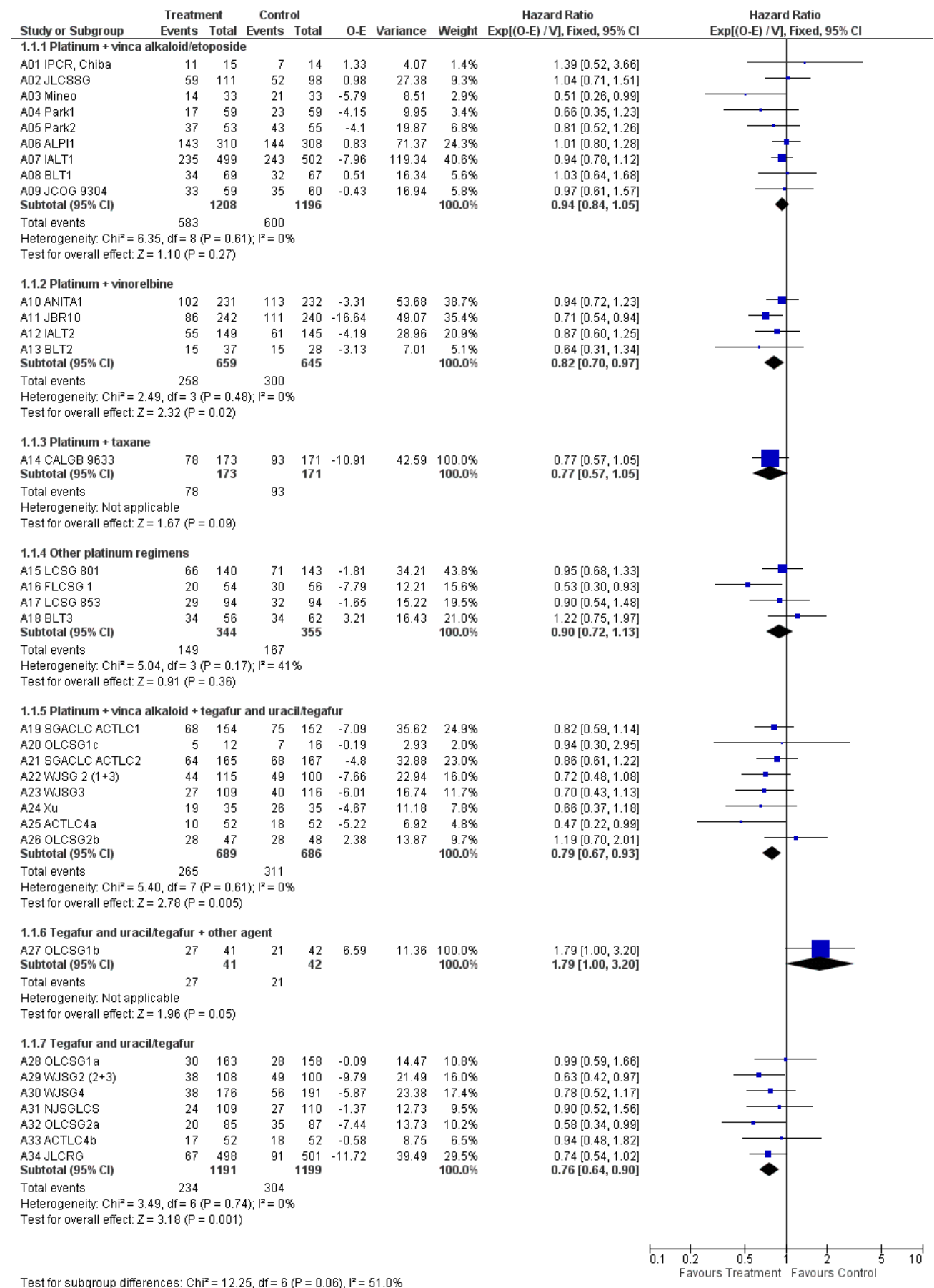

Adjuvant chemotherapy for resected early-stage non-small cell lung cancer (Review) 


\section{Dealing with missing data}

We outlined all desired variables in a protocol (available on request from $\mathrm{SB}$ ). We requested any missing variables from those who carried out the trial.

\section{Assessment of heterogeneity}

We used $\mathrm{Chi}^{2}$ tests and the $\mathrm{I}^{2}$ statistic to test for differences in the treatment effect across groups of trials or groups of patients.

\section{Assessment of reporting biases}

As we collected IPD, we did not encounter any reporting biases.

\section{Data synthesis}

Where we could get data, we included all eligible trials in the analyses. The analyses were carried out in RevMan (RevMan 2014).

\section{Subgroup analysis and investigation of heterogeneity}

To investigate differences in the treatment effect across patient subgroups, we undertook Cox regressions, including the relevant treatment by subgroup interaction term within trials and the interaction coefficients (HRs) pooled across trials (Fisher 2011). We investigated whether there were differences in the treatment effect depending upon the patients' age, sex, histological cell type, tumour stage, or performance status.

\section{Sensitivity analysis}

We outlined in the protocol that HRs for overall survival would be calculated, excluding any trials that were clear outliers.

\section{RE S U L T S}

\section{Description of studies}

\section{Surgery versus surgery plus adjuvant chemotherapy}

We identified 35 eligible trials. We included 26 trials; nine from the 1995 meta-analysis and 17 additional ones (see Characteristics of included studies). We could not include nine trials because data were not available for three published (Ayoub 1991; Clerici 1991; Ichinose 1991) and two unpublished trials (EORTC 08922;
NCCTG 852451) (see Characteristics of excluded studies); adequate contact with the investigators could not be established for two trials (Ueda 2004; Zarogoulidis 1996) and two other trials had only recently been presented (Wang 2009; Wu 2009). Therefore, we included data from 26 published trials, allowing 34 trial comparisons (A01 IPCR, Chiba; A02 JLCSSG; A03 Mineo; A04 Park1; A05 Park2; A06 ALPI1; A07 IALT1; A08 BLT1; A09 JCOG 9304; A10 ANITA1; A11 JBR10; A12 IALT2; A13 BLT2; A14 CALGB 9633; A15 LCSG 801; A16 FLCSG 1; A17 LCSG 853; A1 8 BLT3; A19 SGACLC ACTLC1; A20 OLCSG1c; A21 SGACLC ACTLC2; A22 WJSG $2(1+3)$; A23 WJSG3; A24 Xu; A25 ACTLC4a; A26 OLCSG2b; A27 OLCSG1b; A28 OLCSG1a; A29 WJSG2 (2+3); A30 WJSG4; A31 NJSGLCS; A32 OLCSG2a; A33 ACTLC4b; A34 JLCRG).

Platinum-based chemotherapy, without tegafur plus uracil or tegafur alone was used in 18 trial comparisons (A01 IPCR, Chiba; A02 JLCSSG; A03 Mineo; A04 Park1; A05 Park2; A06 ALPI1; A07 IALT1; A08 BLT1; A09 JCOG 9304; A10 ANITA1; A11 JBR10; A12 IALT2; A13 BLT2; A14 CALGB 9633; A15 LCSG 801; A16 FLCSG 1; A17 LCSG 853; A18 BLT3) and platinum-based chemotherapy with tegafur or with tegafur plus uracil was used in eight (A19 SGACLC ACTLC1; A20 OLCSG1c; A21 SGACLC ACTLC2; A22 WJSG 2 (1+3); A23 WJSG3; A24 Xu; A25 ACTLC4a; A26 OLCSG2b). In all but one (A14 CALGB 9633), cisplatin was the platinum agent. Tegafur or tegafor plus uracil were used in combination with other agents in one trial comparison (A27 OLCSG1b) and alone in seven (A28 OLCSG1a; A29 WJSG2 (2+3); A30 WJSG4; A31 NJSGLCS; A32 OLCSG2a; A33 ACTLC4b; A34 JLCRG). Data on histology and stage were provided for all 34 trial comparisons, age and sex for 33, and performance status for 24 (Table 2). Patients were mostly men with a median age of 61 years (range 18 to 84 ). They tended to have good performance status and tumours that were predominantly stage III adenocarcinomas or squamous cell carcinomas. Staging methods would have changed over time but the methods used were the same in both treatment arms in the trials. We combined the small number of patients with stage IIIB and IV tumours (included for example, because of misclassification at diagnosis (Table 2), with stage IIIA patients for analysis; this group is subsequently referred to as stage III. The median follow-up was 5.5 years.

\section{Surgery plus radiotherapy versus surgery plus radiotherapy plus adjuvant chemotherapy}

We identified 15 eligible trials. We included 12 trials; six from the 1995 meta-analysis and six additional ones (see Characteristics of included studies). We could not include three for the following reasons: data were not available for one trial (Ayoub 1991), and adequate contact with investigators could not be made for 
two trials (Kim 2003; Wolf 2001) (see Characteristics of excluded studies). Therefore, we included nine published and three unpublished trials, allowing 13 trial comparisons (B01 MSKCC 80-53; B02 GETCB 01CB82; B03 EORTC 08861; B04 MDA DM 87045; B05 INT 0115; B06 ALPI2; B07 IALT3; B08 BLT4; B09 ANITA2; B10 IALT4; B11 LCSG 791; B12 FLCSG 3; B13 OLCSG1d).

In nine trial comparisons (B02 GETCB 01CB82; B04 MDA DM 87045; B06 ALPI2; B07 IALT3; B08 BLT4; B09 ANITA2; B10 IALT4; B12 FLCSG 3; B13 OLCSG1d), chemotherapy was given before radiotherapy, and in four it was given concurrently with radiotherapy (B01 MSKCC 80-53; B03 EORTC 08861; B05 INT 0115; B11 LCSG 791). Platinum and a vinca alkaloid or etoposide were used in 10 trial comparisons (B01 MSKCC 80-53; B02 GETCB 01CB82; B03 EORTC 08861; B04 MDA DM 87045; B05 INT 0115; B06 ALPI2; B07 IALT3; B08 BLT4; B09 ANITA2; B10 IALT4), platinum and tegafur plus uracil/tegafur in one (B13 OLCSG1d), and other platinum regimens in two trials (B11 LCSG 791; B12 FLCSG 3). Cisplatin was the sole platinum agent. Data on age, sex and histology were supplied for all trial comparisons, stage and extent of resection for 12 , and performance status for 11 . Based on these data, patients were mostly men, with good performance status, a median age of 59 years (range 27 to 81), and stage III, squamous carcinomas. We combined the few patients with stage IV tumours with stage III patients for analyses, and referred to this group as stage III. The median follow-up was 6.4 years.

\section{Risk of bias in included studies}

We only included trials with adequate methods of randomisation. We excluded trials using quasi-random methods, such as birth date. We thoroughly checked all raw data received on individual patients to ensure both the accuracy of the meta-analysis database and the quality of randomisation and follow-up. We resolved any queries and verified the final database entries by discussion with the responsible trial investigator or statistician. No RCTs were blinded due to the nature of the intervention, but the primary outcome is not likely to be influenced by the lack of blinding. We received IPD for all outcomes of interest, therefore we considered reporting bias to be low for all RCTs. We considered all included trials to be at a low risk of bias (see Figure 2 and Figure 3).

Figure 2. Methodological quality graph: review authors' judgements about each methodological quality item presented as percentages across all included studies.

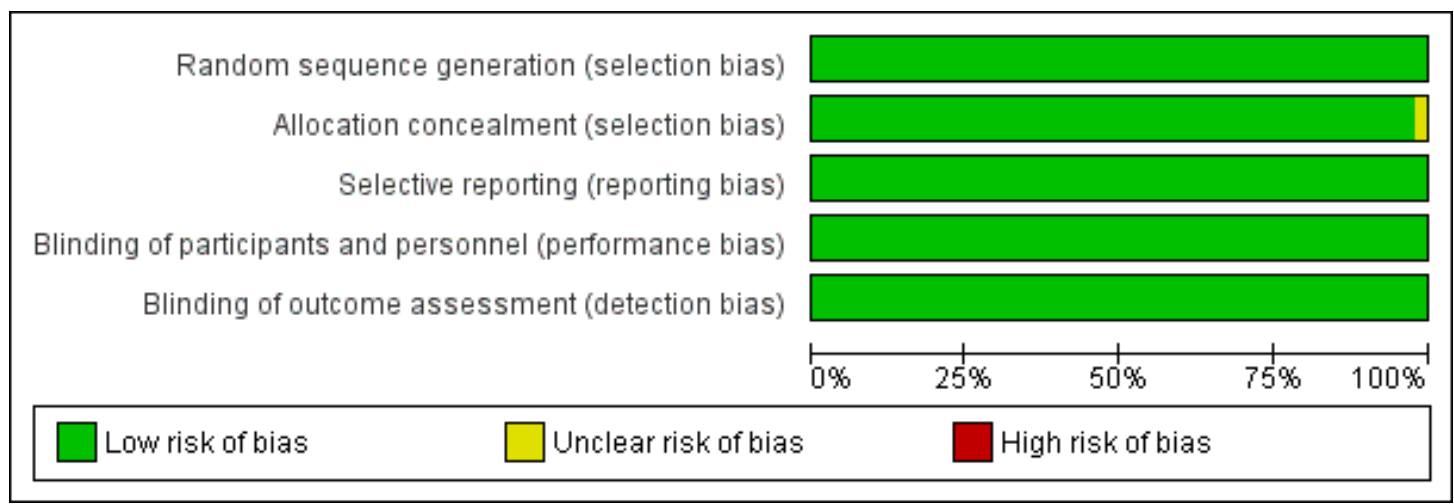

Adjuvant chemotherapy for resected early-stage non-small cell lung cancer (Review) 
Figure 3. Methodological quality summary: review authors' judgements about each methodological quality item for each included study.

\begin{tabular}{|c|c|c|c|c|c|}
\hline & 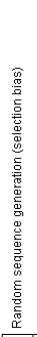 & 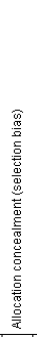 & 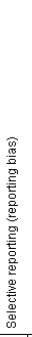 & & 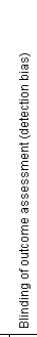 \\
\hline A01 IPCR, Chiba & ๑ & ๑ & (๑) & () & 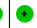 \\
\hline A02 JLCSSG & (๑) & ๑ & ๑) & () & (†) \\
\hline A03 Mineo & ๑) & ๑ & ๑ & ๑ & 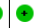 \\
\hline A04 Park1 & ๑) & ๑ & • & ๑) & 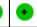 \\
\hline A05 Park2 & (๑) & (๑) & (†) & (ㄷ) & $\oplus$ \\
\hline A06 ALP11 & (๑) & (๑) & ๑) & () & $\odot$ \\
\hline A07 IALT1 & (๑) & (๑) & (๑) & () & $\odot$ \\
\hline A08 BLT1 & ๑) & $\oplus$ & ๑) & ๑) & ๑ \\
\hline A09 JCOG 9304 & ๑ & ๑ & ๑) & • & - \\
\hline A10 ANITA1 & ๑) & • & - & • & $\odot$ \\
\hline A11 JBR10 & ๑ & ๑ & ๑ & ๑) & 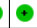 \\
\hline A12 IALT2 & ๑) & ๑) & ๑ & ๑) & - \\
\hline A13 ELT2 & ( & ๑) & ๑ & ๑) & $\odot$ \\
\hline A14 CALGB 9633 & (๑) & $\odot$ & (†) & ๑ & $\odot$ \\
\hline A15 LCSG 801 & ๑ & (๑) & - & ๑) & $\odot$ \\
\hline A16 FLCSG 1 & ๑) & ๑) & (๑) & ๑) & - \\
\hline A17 LCSG 853 & ๑ & ๑ & ๑ & ๑ & $\bullet$ \\
\hline A18 BLT3 & ๑ & ๑) & ๑) & ๑) & 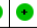 \\
\hline A19 SGACLC ACTLC1 & ๑) & ๑) & ๑ & ๑) & $\odot$ \\
\hline A20 OLCSG1C & ๑ & ๑) & ๑ & ๑) & - \\
\hline A21 SGACLC ACTLC2 & $\odot$ & ๑ & ๑) & ๑ & 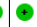 \\
\hline A22 WUSG 2 (1+3) & (๑) & (๑) & ๑) & ๑) & ๑ \\
\hline A23 WUSG 3 & (๑) & ๑ & (๑) & () & $\odot$ \\
\hline A24 $\times u$ & ๑) & (๑) & ๑) & ๑) & - \\
\hline A25 ACTLC4a & ๑) & ๑) & ๑ & () & $\odot$ \\
\hline A26 OLCSO $2 b$ & ๑) & (๑) & ๑) & ๑) & $\odot$ \\
\hline A27 OLCSG1b & ๑) & (๑) & (๑) & (๑) & - \\
\hline A28 OLCSG1a & (๑) & (๑) & () & () & ๑ \\
\hline A29 WuSG2 $2(2+3)$ & ๑) & ๑ & ๑) & () & 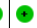 \\
\hline A30 WUSG 4 & (๑) & (๑) & () & () & $\odot$ \\
\hline A31 NJSGLCS & ๑) & ๑) & ๑) & () & ๑ \\
\hline A32 OLCSG2a & ๑ & ๑) & ๑) & () & 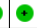 \\
\hline Aз3 ACTLC $4 \mathrm{~b}$ & ๑) & ๑ & ๑ & ๑ & $\odot$ \\
\hline A34 JLCRG & ๑ & (๑) & - & ๑ & - \\
\hline B01 MSKCC 80-53 & ๑) & $?$ & ๑) & () & 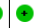 \\
\hline B02 GETCB 01 CB82 & ๑ & ๑ & ๑ & ๑) & $\odot$ \\
\hline B03 EORTC 08861 & (๑) & ๑) & ๑) & () & ๑ \\
\hline B04 MDA DM 87045 & ๑) & ๑) & ๑) & ๑) & (๑) \\
\hline Bo5 INT 0115 & (๑) & ๑) & ๑) & () & $\odot$ \\
\hline B06 ALP12 & ๑ & ๑ & ๑ & ๑ & 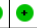 \\
\hline B07 IALT3 & ๑ & ๑) & ๑ & ๑ & $\odot$ \\
\hline B08 BLT4 & ๑) & (๑) & ๑) & (ㄷ) & $\odot$ \\
\hline B09 ANITA2 & ๑ & ๑ & (๑) & - & - \\
\hline B10 IALT4 & ๑ & ๑) & ๑ & • & $\odot$ \\
\hline B11 LCSG 791 & ๑ & ๑ & ๑) & ๑ & $\oplus$ \\
\hline B12 FLCSG 3 & (๑) & ๑) & ๑) & • & 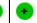 \\
\hline B13 OLCSG1d & ๑) & ๑ & - & • & $\odot$ \\
\hline
\end{tabular}




\section{Effects of interventions}

\section{Surgery versus surgery plus adjuvant chemotherapy}

Overall survival results for the first meta-analysis were based on 34 trial comparisons and 8447 patients (3323 deaths), representing $92 \%$ of patients who were randomly assigned. The results (Analysis 1.1) show a benefit of adjuvant chemotherapy (hazard ratio (HR) $0.86,95 \%$ confidence interval (CI) 0.81 to $0.92, \mathrm{p}<0.0001$; Figure $1)$, with minimum heterogeneity $\left(\mathrm{p}=0.40, \mathrm{I}^{2}=4 \%\right)$. This finding represents an absolute improvement of $4 \%$ (95\% CI 3 to 6$)$ at five years, increasing overall survival from $60 \%$ to $64 \%$ (Figure 4 ). We noted a difference in effect by chemotherapy category (interaction $\mathrm{p}=0.06$, Figure 1), largely driven by the result of the trial comparison,A27 OLCSG1b, that alone constituted the chemotherapy category for tegafur plus uracil or tegafur plus another agent. A sensitivity analysis excluding this trial did not suggest that this drug regimen affects the effect of adjuvant chemotherapy (data not shown; interaction $\mathrm{p}=0.30$ ).

Figure 4. Simple (non-stratified Kaplan-Meier curves for trials of Surgery (S) and chemotherapy (CT) versus surgery alone and for trials of surgery and chemotherapy and radiotherapy (RT) versus surgery and radiotherapy.

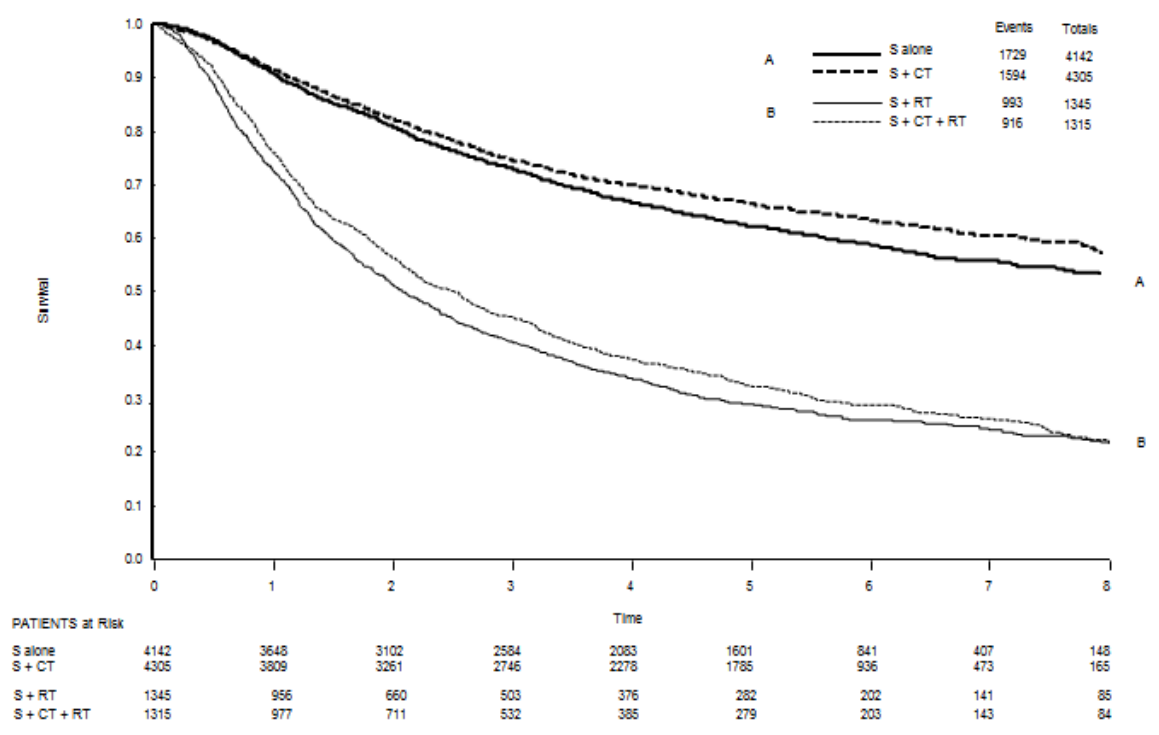

In view of the differences in the types of chemotherapy used over time and by geographical region, we grouped trial comparisons by these characteristics for exploratory analyses. We noted no clear evidence of a difference in the effect between trial comparisons included in the 1995 meta-analysis, and those included since this time (interaction $\mathrm{p}=0.76$ ), by accrual decade (interaction $\mathrm{p}=0.61$ ), or by geographical region (North America, Europe, Asia; interaction $\mathrm{p}=0.25$; data not shown). Trial comparisons using tegafur plus uracil or tegafur alone all originated in Asia, and recruited more women $(\mathrm{n}=1293$ of $3465(37 \%))$, and more patients with stage I tumours (3003/3673 (82\%)) of adenocarcinoma histology
$(2505 / 3673(68 \%))$ than those that did not use tegafur plus uracil or tegafur alone (1093/4745 (23\%)), (2613/4724 (55\%)), (1910/ $4744(40 \%))$, respectively. However, we recorded no clear evidence of a difference in treatment effect between trial comparisons that did (3848 (45\%); HR 0.80, 95\% CI 0.71 to 0.90$)$ and those that did not (4751 (55\%); HR 0.89, 95\% CI 0.82 to 0.97 ) use tegafur plus uracil or tegafur alone (overall HR $0.86,95 \%$ CI 0.81 to 0.92 , interaction $\mathrm{p}=0.16$; Figure 5 ), even when we excluded the trial comparison A27 OLCSG1b (data not shown; interaction $\mathrm{p}$ $=0.07$ ). 
Figure 5. Exploratory analyses of the effect of surgery (S) and chemotherapy (CT) versus surgery on survival, by the use of tegafur plus uracil/tegafur.

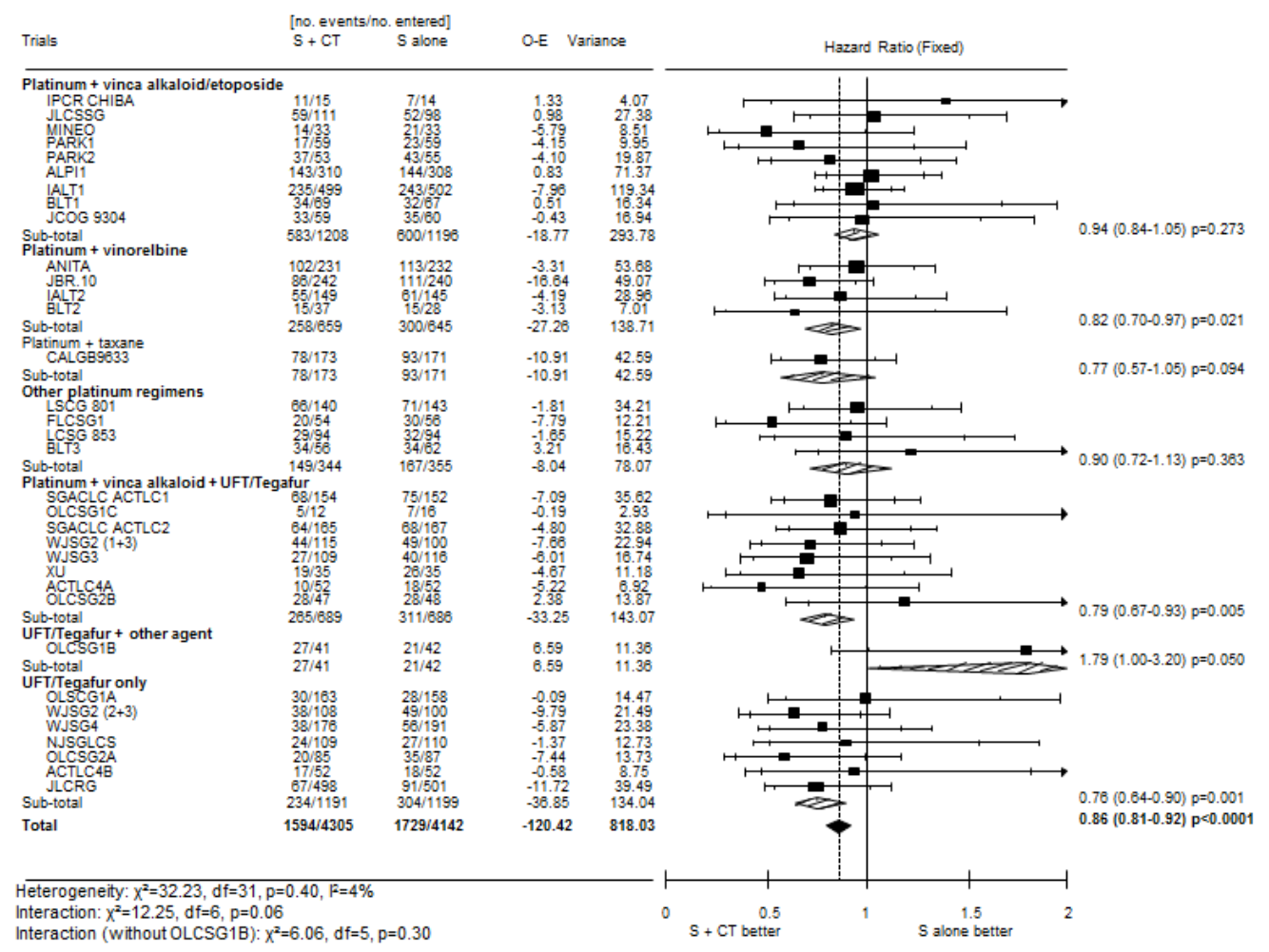

We recorded no significant evidence $(\mathrm{p} \geq 0.10)$ that any patient subgroup defined by age, sex, histology, performance status, or stage benefited more or less from adjuvant chemotherapy (Figure 6). However, because of the geographical differences in the types of patients and chemotherapy used, we undertook exploratory subgroup analyses separately for trial comparisons using platinum, without tegafur plus uracil or tegafur alone, and those using these drugs. We split stage I disease into IA and IB for all but five trial comparisons (A04 Park1; A19 SGACLCACTLC1; A21 SGACLC ACTLC2; A26 OLCSG2b; A32 OLCSG2a) which we had to exclude since this information was not available. 
Figure 6. The effect of surgery (S) and chemotherapy (CT) versus surgery on survival by patient subgroup.

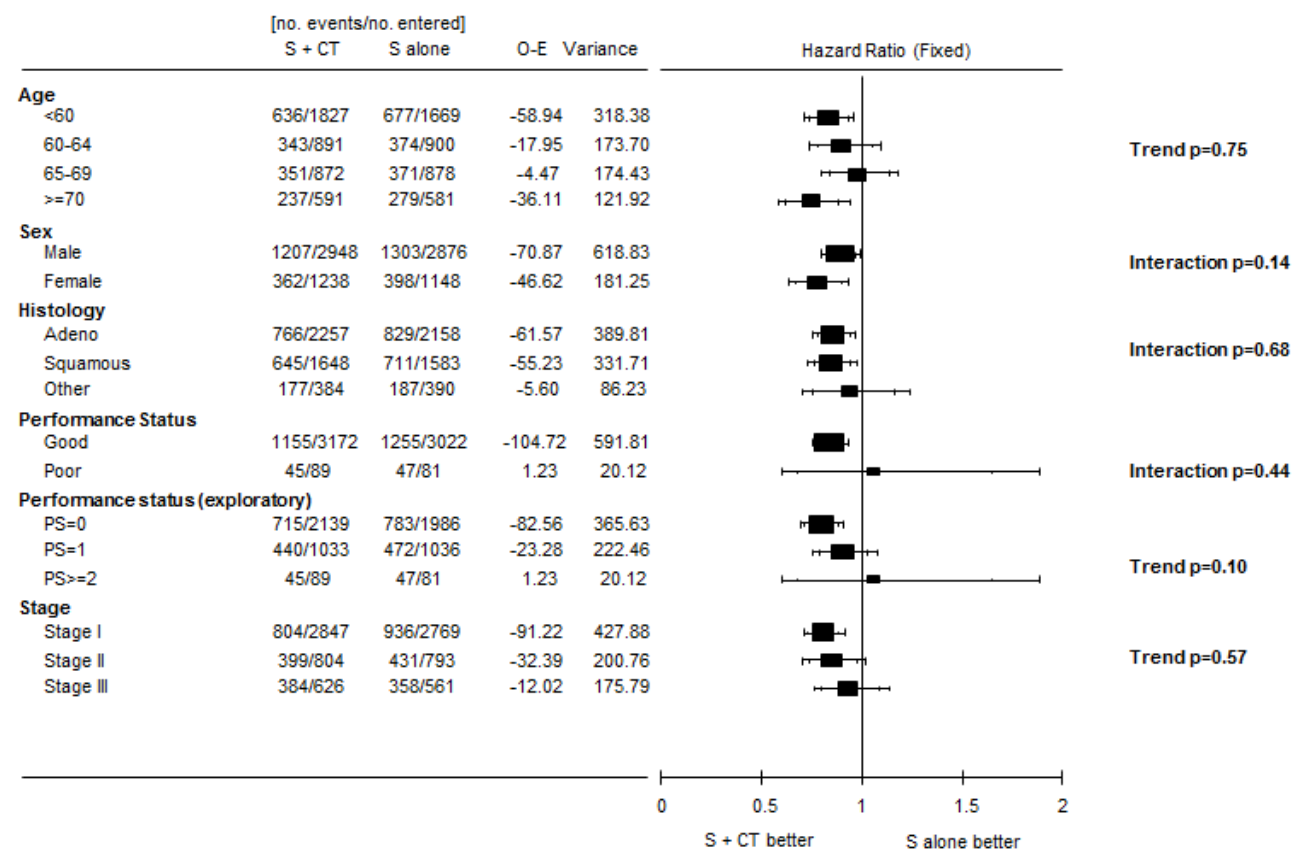

For the platinum without tegafur plus uracil or tegafur alone group, although there was no evidence of difference in the effect of adjuvant chemotherapy between patients with good and poor performance status (interaction $\mathrm{p}=0.30$; Figure 7 ), we noted an increasing relative effect of adjuvant chemotherapy with improving performance status (trend $\mathrm{p}=0.002$; Figure 7), which was consistent across trials (data not shown; $\mathrm{p}=0.32$ ). However, a few patients had a poor performance status (Figure 7). The relative effect of adjuvant chemotherapy did not differ significantly by other patient subgroups, including stage (trend $\mathrm{p}=0.13$; Figure
7). Therefore, application of the overall hazard ratio to survival in the control group by stage suggests absolute improvements in 5year survival of $3 \%$ (95\% CI 2 to 5) for stage IA (from $70 \%$ to $73 \%$ ), $5 \%$ (2 to 7 ) for stage IB (from $55 \%$ to $60 \%$ ), $5 \%$ (3 to 8) for stage II (from $40 \%$ to $45 \%$ ), and $5 \%$ (3 to 8 ) for stage III disease (from $30 \%$ to $35 \%$ ). The suggested survival benefit of $3 \%$ for stage IA and the hazard ratio of 1.19 (95\% CI 0.84 to 1.68$)$ for that subgroup seemed to be contradictory. However, data are scarce for this group of patients, the CIs are very wide, and the result is not significant $(\mathrm{p}=0.33)$. 
Figure 7. Exploratory analyses of the effect of surgery (S) and chemotherapy (CT) versus surgery on survival, by use of tegafur plus uracil or tegafur and by stage and performance status.

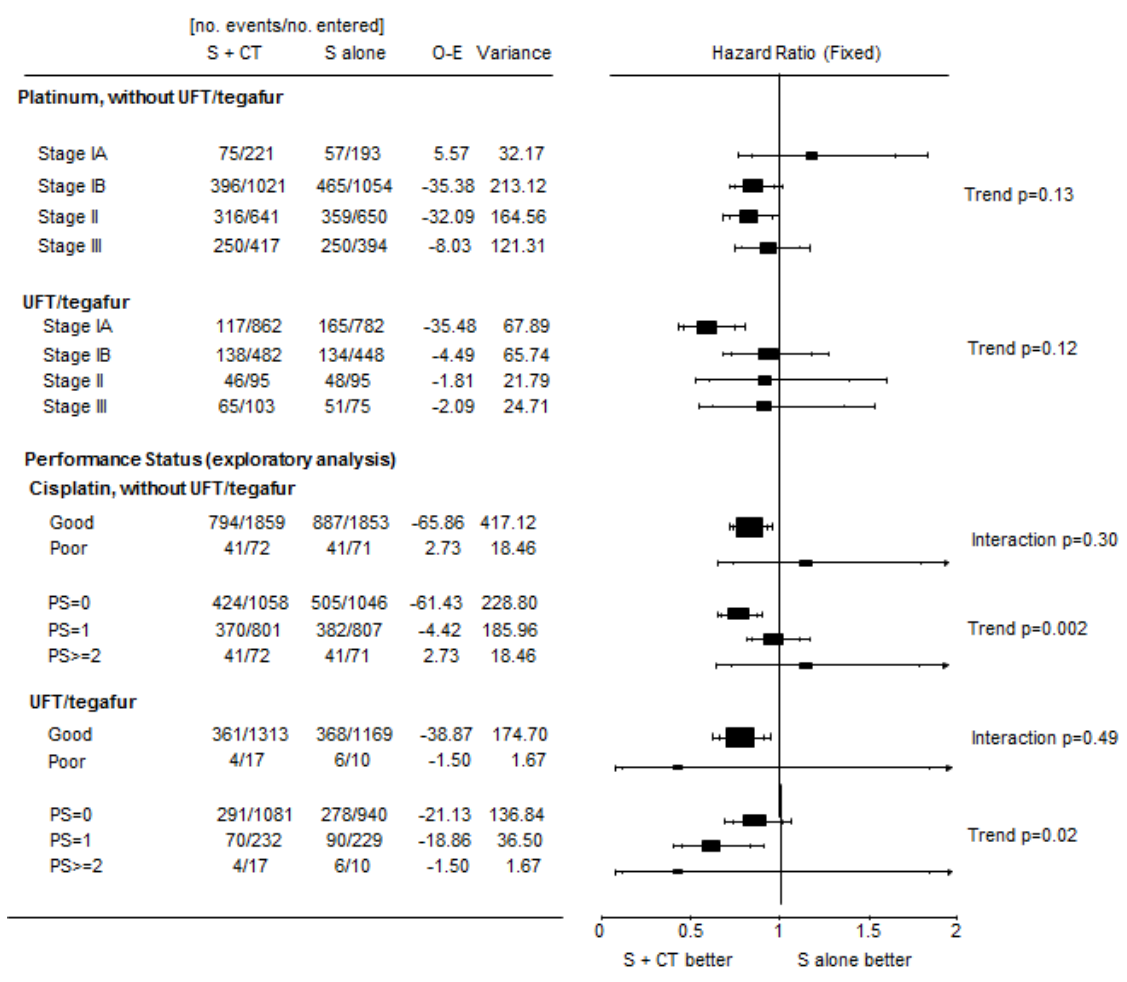

In the tegafur and uracil or tegafur alone group, we noted no clear difference in the effect of adjuvant chemotherapy between patients with good or poor performance status (interaction $\mathrm{p}=0.49$; Figure 7), but did record a suggestion of an increasing relative effect of adjuvant chemotherapy with worsening performance status (trend $\mathrm{p}=0.02$; Figure 7 ). This trend varies substantially across trials (data not shown; $\mathrm{p}=0.01$ ), and few patients had a poor performance status. We noted no significant difference in the relative effect of adjuvant chemotherapy by age, sex, histology, or stage, and application of the overall HR gave absolute improvements in 5year survival of $2 \%$ (95\% CI 1 to 3 ) for stage IA (from $80 \%$ to $82 \%$ ), $3 \%$ ( 1 to 4 ) for stage IB (from $75 \%$ to $78 \%$ ), $5 \%$ (2 to 7) for stage II (from $45 \%$ to $50 \%$ ), and $5 \%$ (3 to 8 ) for stage III disease (from $25 \%$ to $30 \%$ ).

Data for recurrence-free survival were available for 18 trial comparisons (2519 events; 5379 patients) and data for locoregional (936 events; 5226 patients) and distant recurrence (1267 events; 5224 patients) for 16 trial comparisons, mostly from newer trials of platinum-based chemotherapy without tegafur plus uracil or tegafur alone. Results for recurrence-free survival (HR 0.83, 95\% CI 0.77 to $0.90, \mathrm{p}<0.0001)$, time to locoregional recurrence (HR $0.75,95 \% \mathrm{CI} 0.66$ to $0.85, \mathrm{p}<0.0001)$, and time to distant recurrence (HR $0.80,95 \%$ CI 0.72 to $0.89, \mathrm{p}=0.0007$ ) all significantly

favoured adjuvant chemotherapy. Exclusion of the four trial comparisons that included tegafur plus uracil or tegafur alone (A23 WJSG3; A24 Xu; A33 ACTLC4b; A34 JLCRG) showed similar results (data not shown).

Surgery plus radiotherapy versus surgery plus radiotherapy plus adjuvant chemotherapy

Overall survival analyses were based on 12 trial comparisons and 2660 patients (1909 deaths), representing $86 \%$ of patients who were randomly assigned. The results (Analysis 2.1) showed a clear benefit of adjuvant chemotherapy (HR $0.88,95 \%$ CI 0.81 to 0.97 , $\mathrm{p}=0.009$; Figure 8$)$, with little heterogeneity $\left(\mathrm{p}=0.95, \mathrm{I}^{2}=0 \%\right)$. This finding represents an absolute benefit of 4\% (95\% CI 1 to 8 ) at 5 years, increasing survival from $29 \%$ to $33 \%$ (Figure 4). We recorded no evidence of a differential effect by chemotherapy category (interaction $\mathrm{p}=0.45$; Figure 8 ) or the extent of resection achieved: trials with complete resection only (6 trials, $2005 \mathrm{pa}-$ tients; HR 0.87, 95\% CI 0.78 to 0.97 ) versus trials with complete or incomplete resection ( 6 trials, 655 patients; HR $0.92,95 \%$ CI 0.78 to 1.08 ); interaction $\mathrm{p}=0.63$. Furthermore, an exploratory analysis suggests that the timing of chemotherapy in relation to 
radiotherapy is unimportant: trials with chemotherapy before radiotherapy ( 9 trials, 1928 patients; HR $0.86,95 \%$ CI 0.77 to $0.96)$ versus trials with concomitant chemoradiotherapy $(3$ trials, 732 patients; HR 0.95 , 95\% CI 0.81 to 1.12 ); interaction $\mathrm{p}=$ 0.30 .

Figure 8. Forest plot of comparison: 2 surgery + radiotherapy versus surgery + radiotherapy + chemotherapy, outcome: 2 .I Survival.

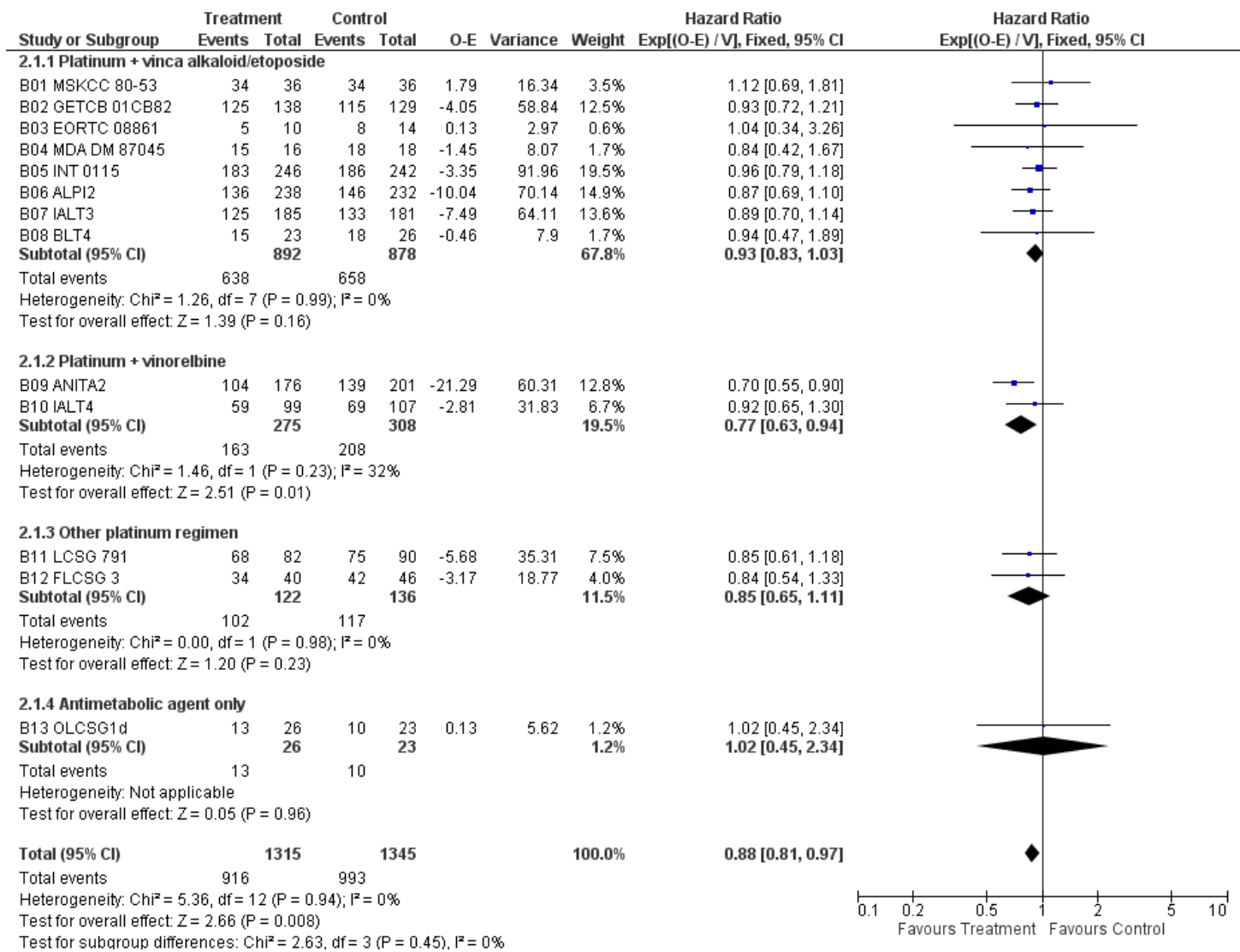

The relative effect of adjuvant chemotherapy did not differ significantly by age, sex, histology, performance status, or stage (Figure 9). Data for recurrence-free survival, and locoregional and distant recurrence were available for eight trial comparisons (2247 patients). Results for recurrence-free survival (1673 events, 2247 patients; HR $0.85,95 \%$ CI 0.77 to $0.93, \mathrm{p}=0.0006$ ), time to locoregional recurrence (533 events; HR 0.79 , 95\% CI 0.67 to $0.94, \mathrm{p}=0.008$ ), and time to distant recurrence (806 events; HR $0.75,95 \%$ CI 0.66 to $0.87, \mathrm{p}<0.0001$ ) all showed a significant benefit of adjuvant chemotherapy. 
Figure 9. The effect of surgery (S) and radiotherapy (RT) and chemotherapy (CT) versus surgery and radiotherapy on survival by patient subgroup.

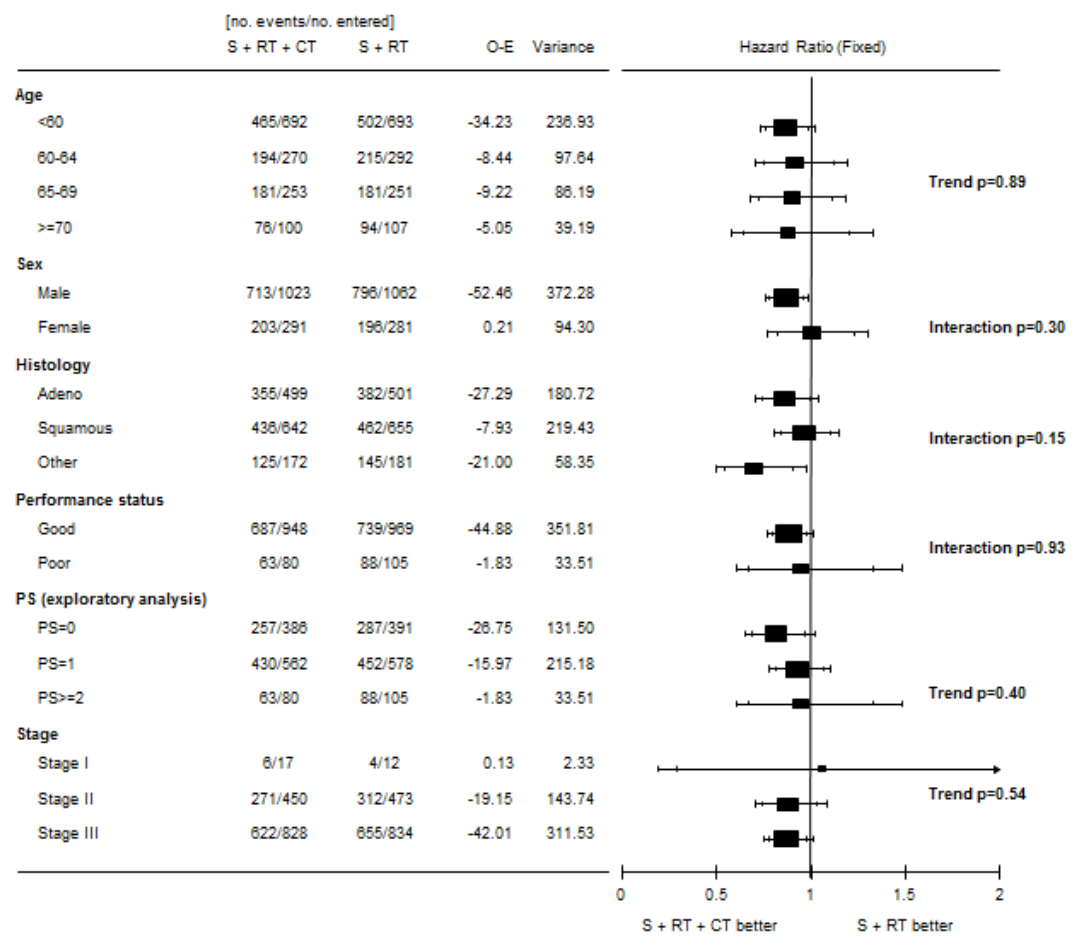

\section{DISCUSSION}

\section{Summary of main results}

Our results show a benefit of adjuvant chemotherapy after surgery, which has been already shown in some large trials but not in others (for example, A06 ALPI1 and A14 CALGB 9633). They also show a benefit of chemotherapy in the presence of postoperative radiotherapy. The absolute survival improvements of $4 \%$ at five years are fairly modest, but might result in 10,000 to 16,000 more patients alive at five years (Datta 2003). The results of the two meta-analyses are based on data from 47 comparisons in 33 trials and 11,107 patients with non-small cell lung cancer (NSCLC), which is more than three times that available in the NSCLC Collaborative Group 1995. In these meta-analyses, we have an opportunity to bring together most trials undertaken during the past few decades, and to assess the effectiveness of adjuvant chemotherapy in patients with NSCLC worldwide.

Although we noted no significant difference in effect between chemotherapy categories in the first meta-analysis, results for the trials that used older vinca alkaloids (vinblastine, vindesine, vincristine), etoposide, or other platinum combinations were somewhat uncertain, whereas trials using a combination of platinum and vinorelbine provided slightly more reliable evidence of benefit to inform present clinical practice (Figure 1; Figure 8). The results for chemotherapy with tegafur plus uracil or tegafur alone are similar to those for platinum-based regimens. However, results come largely from older studies in Asian populations, which are increasingly showing differences in their response to treatment (Sekine 2008), and so cannot be extrapolated to modern practice in non-Asian patients. A trial of tegafur plus uracil or tegafur alone in patients with stage IA, adenocarcinoma from non-Asian countries would be beneficial in this context. Results of an ongoing trial might establish the relative merits of carboplatin-paclitaxel and tegafur plus uracil in Asian patients (Toyooka 2009).

Guidelines from Cancer Care Ontario and American Society of Clinical Oncology (ASCO) (Pisters 2007) recommend that adjuvant cisplatin-based chemotherapy is given to patients with stage II and IIIA NSCLC.

These guidelines state that evidence is insufficient to make recommendations for patients with stage IA disease, and one metaanalysis (Pignon 2008) reported a significant decrease in the effect of adjuvant cisplatin-based chemotherapy by stage, largely driven by the stage IA result. This meta-analysis does not show signifi- 
cant differences in the effect of platinum chemotherapy (without tegafur plus uracil or tegafur alone) by stage or significantly poorer survival in patients with stage IA disease (Figure 7). The evidence in stage IA tumours remains scarce until results from further trials are available.

The ASCO guidelines also state that none of the studies reviewed showed a significant benefit of adjuvant chemotherapy in patients with stage IB tumours. By contrast, our estimate of the effect of platinum-based adjuvant chemotherapy in patients with stage IB tumours is based on a substantial number of events and is similar to estimates for patients with stage II and III tumours (Figure 7). Since we did not collect data for tumour size, patients with larger stage IB tumours, who would be classed as stage II in the 7th edition of the TNM staging system (IASLC 2009) and might achieve a greater benefit from adjuvant chemotherapy are potentially included. In the absence of comorbidities and contraindications to chemotherapy, our findings show that adjuvant platinumbased chemotherapy may be considered as a treatment option for patients at high risk of recurrence, ie, those with stage IB, II, or III disease. Whethercisplatin-based chemotherapy should be used in patients with stage IA disease remains uncertain, since the scarcity of data did not allow us to distinguish reliably between a benefit, a detriment, or no effect. Most patients had good performance status and the benefit was clear in this group. A small increasing effect of platinum-based chemotherapy with better performance status was also apparent in this and another meta-analysis (Pignon 2008), but was not confirmed in trials using tegafur plus uracil or tegafur alone, or those that included postoperative radiotherapy. Nevertheless, these results could suggest cautious use of platinumbased chemotherapy in less fit patients. Despite the amount of data collected, some of the subgroup analyses lacked power.

The benefits of adjuvant chemotherapy have been reported to be attenuated in long-term results (Arriagada 2010; Butts 2010), however, we do not have much data beyond five years. The potential benefit of adjuvant chemotherapy should always be balanced with possible toxic effects for the individual patient. We were unable to assess toxic effects of treatment in this study. Moreover, extrapolation of the results to patients with comorbidities is uncertain because most of the patients included in these meta-analyses had mild or no comorbidities. Quality of life was measured in only a few trials and so could not be reviewed.

\section{Overall completeness and applicability of evidence}

\section{Surgery versus surgery plus adjuvant chemotherapy}

We identified 35 eligible trials and included 26. We could not include nine trials; five could not be included as data were not available; two could not be included as adequate contact could not be made with the trial investigators; and two were published too recently to be included (but will be included in a subsequent update). Therefore this represents $92 \%$ of all patients who were randomised into eligible trials.

\section{Surgery plus radiotherapy versus surgery plus radiotherapy plus adjuvant chemotherapy}

We identified 15 eligible trials and included 12. We could not include three trials; one could not be included as data were not available; and two could not be included as adequate contact could not be made with the trial investigators. Therefore this represents $86 \%$ of all patients who were randomised into eligible trials.

\section{Quality of the evidence}

The trials included in this update show an overall low risk of bias in the domains we considered to be most important; those being adequate sequence generation and allocation concealment. Blinding was not appropriate due to the nature of the treatments and any issues surrounding the reporting of incomplete outcome data, selective outcome reporting or attrition bias were overcome by the collection of individual participant data. We are confident that further research is unlikely to change the findings. The studies were well designed and conducted, address the review question and the effects are consistent across trials. The impact of any data we have not been able to include in our analyses is small.

\section{Potential biases in the review process}

We aimed to include all trials, unpublished and unpublished, regardless of the language they were published in. We collected IPD for all included trials. The first meta-analysis (surgery versus surgery plus adjuvant chemotherapy) included $92 \%$ of eligible data and the second meta-analysis (surgery plus radiotherapy versus surgery plus radiotherapy plus adjuvant chemotherapy) included $86 \%$ of eligible data. Had we been able to include this extra data, it is unlikely they would have had an impact on these results. We checked and verified data against the published results. We resolved any queries and verified the final database by each trial investigator or statistician. We deemed all included trials to have a low risk of bias using the 'Risk of bias' tool.

\section{Agreements and disagreements with other studies or reviews}

This is an update and extension of a previous systematic review and meta-analysis. The results are still in favour of the addition of chemotherapy to surgery and postoperative radiotherapy, however these results are more up to date and contain more than three times more patients than that available in 1995. 


\section{AUTHORS' CONCLUSIONS}

\section{Implications for practice}

The addition of chemotherapy following surgery and postoperative radiotherapy gave a $4 \%$ improvement in 5 -year survival from $29 \%$ to $33 \%$. This benefit should be balanced against possible toxicity and quality of life. Where toxicity was assessed and mentioned in the publications, it was thought to be manageable. This $4 \%$ increase does not seem to vary with the timing of chemotherapy in relation to radiotherapy, extent of surgery, or by patient subgroup (Figure 6; Figure 9). The lower survival rates than those in the surgery and chemotherapy meta-analysis are most likely because patients with stage III tumours predominate and the incomplete resection rate is higher (Table 2). A previous meta-analysis (PORT 1998; PORT 2005) has shown that postoperative radiotherapy has a detrimental effect on survival, particularly for early stage tumours, but old radiotherapy techniques were used.

\section{Implications for research}

This meta-analysis was not designed to study the effect of postoperative radiotherapy, but has shown that the effect of chemotherapy is similar, irrespective of what locoregional treatment is used: surgery alone or surgery plus postoperative radiotherapy. Randomised trials are needed to assess whether modern radiotherapy is effective as an adjuvant treatment. Since this review was completed, we have found further eligible trials (NATCH 2010; Wang 2009; Zheng 2011); (see Characteristics of studies awaiting classification and Characteristics of excluded studies) it is hoped that we will be able to include these trials in a future update of this project.

\section{ACKNOWLEDG M M N T S}

The MRC Project Management Group was funded by the UK Medical Research Council, and the IGR Project Management Group was supported by Institut Gustave-Roussy, Programme Hospitalier de Recherche Clinique (AOM 05 209), Ligue Nationale Contre le Cancer, and Sanofi-Aventis (unrestricted grants).

We thank all patients who took part in the trials and contributed to this research. The meta-analysis would not have been possible without their participation or without the collaborating institutions that provided their trial data.

In addition to the listed authors, we also thank the following for provision of trial data: B Dautzenberg, Groupe Hospitalier Pitié Salpêtrière, Paris (GETCB 01CB82); M Imaizumi, Nagoya University School of Medicine, Nagoya, Japan (SGACLC ACTLC1, ACTLC2, ACTLC4); JH Park, Korea Cancer Center Hospital, Seoul, South Korea (PARK1, PARK2); S Pyrhönen, Turku University Central Hospital, Turku, Finland (FLCSG1, FLCSG3); GM Strauss, Tufts Medical Center, Boston, MA, USA (CALGB 9633); H Wada, Kyoto University, Kyoto, Japan (WJSG2, WJSG3, WJSG4).

We thank Estelle Rolland and Audrey Mauguen for their help in the analysis of the meta-analysis of adjuvant chemotherapy plus surgery and radiotherapy; and Catherine Hill for her comments on the report.

We also thank the Lancet for permission to publish this review (NSCLC Meta-analysis Collaborative Group 2010).

\section{RE F E R E N C E S}

\section{References to studies included in this review}

A01 IPCR, Chiba \{published and unpublished data\}

Kimura H, Yamaguchi Y, Fujisawa T, Baba M, Shiba M. A randomized controlled study of postoperative adjuvant chemoimmunotherapy of resected non-small cell lung cancer with IL2 and LAK cells. Lung Cancer 1991;7(Suppl): 113.

A02 JLCSSG \{published and unpublished data\}

Ohta M, Tsuchiya R, Shimoyama M, Sawamura K, Mori T, Miyazawa N, et al. Adjuvant chemotherapy for completely resected stage III non-small cell lung cancer. Journal of Thoracic and Cardiovascular Surgery 1993;106:703-8.

A03 Mineo \{published and unpublished data\}

Mineo TC, Ambrogi V, Corsaro V, Roselli M. Postoperative adjuvant therapy for stage IB non-small cell lung cancer. European Journal of Cardio-Thoracic Surgery 2001;20(2): 378-84.
A04 Park1 \{published and unpublished data\} Park JH, Lee C-T, Lee HW, Baek HJ, Zo JI, Shim YM. Postoperative adjuvant chemotherapy for stage I non-small cell lung cancer. European Journal of Cardio-Thoracic Surgery 2005;27:1086-91.

A05 Park2 \{published and unpublished data\} Park JH. Postoperative adjuvant therapy for stage IIIA nonsmall cell lung cancer. Journal of Thoracic Oncology 2007;2 (8 Suppl 4):S651.

A06 ALPI1 \{published and unpublished data\} Scagliotti GV, Fossati R, Torri V, Crinò L, Giaccone G, Silvano G, et al. Randomized study of adjuvant chemotherapy for completely resected stage I, II or IIIa non-small cell lung cancer. Journal of the National Cancer Institute 2003;95(19):1453-61.

A07 IALT1 \{published and unpublished data\} Arriagada R, Dunant A, Pignon J-P, Bergman B, Chabowski $M$, Grunenwald D, et al. Long-term results of the 
International Adjuvant Lung Cancer Trial evaluating adjuvant cisplatin-based chemotherapy in resected lung cancer. Journal of Clinical Oncology 2010;28:35-42.

The International Adjuvant Lung Cancer Trial Collaborative Group. Cisplatin-based adjuvant chemotherapy in patients with completely resected non-small cell lung cancer. New England Journal of Medicine 2004;350:351-60.

\section{A08 BLT1 \{published and unpublished data\}}

Waller D, Peake MD, Stephens RJ, Gower NH, Milroy R, Parmar MKB, et al. Chemotherapy for patients with nonsmall cell lung cancer: the surgical setting of the Big Lung Trial. European Journal of Cardio-Thoracic Surgery 2004;26: $173-82$.

A09 JCOG 9304 \{published and unpublished data\} Tada H, Tsuchiya R, Ichinose Y, Koike T, Nishizawa N, Nagai K, et al. A randomized trial comparing adjuvant chemotherapy versus surgery alone for completely resected pN2 non-small cell lung cancer (JCOG 9304). Lung Cancer 2004;43:167-73.

A10 ANITA1 \{published and unpublished data\} Douillard JY, Rosell R, De Lena M, Carpagnano F, Ramlau $\mathrm{R}$, Gonzales-Larriba JL, et al. Adjuvant vinorelbine plus cisplatin versus observation in patients with completely resected stage IB-IIIA non-small-cell lung cancer (Adjuvant Navelbine International Trialist Association [ANITA]): a randomised controlled trial. Lancet Oncology 2006;7: 719-27.

A11 JBR10 \{published and unpublished data\} Butts CA, Ding K, Seymour L, Twumasi-Ankrah P, Graham B, Gandara D, et al. Randomised phase III trial of vinorelbine plus cisplatin compared with observation in completely resected stage Ib and II non-small cell lung cancer: Updated survival analysis of JBR-10. Journal of Clinical Oncology 2010;28:29-34.

Winton T, Livingston R, Johnson D, Rigas J, Johnston M, Butts $\mathrm{C}$, et al. Vinorelbine plus cisplatin vs observation in resected non-small cell lung cancer. New England Journal of Medicine 2005;352:2589-97.

A12 IALT2 \{published and unpublished data\} Arriagada R, Dunant A, Pignon J-P, Bergman B, Chabowski $M$, Grunenwald $\mathrm{D}$, et al. Long-term results of the International Adjuvant Lung Cancer Trial evaluating adjuvant cisplatin-based chemotherapy in resected lung cancer. Journal of Clinical Oncology 2010;28:35-42.

The International Adjuvant Lung Cancer Trial Collaborative Group. Cisplatin-based adjuvant chemotherapy in patients with completely resected non-small cell lung cancer. New England Journal of Medicine 2004;350:351-60.

A13 BLT2 \{published and unpublished data\} Waller D, Peake MD, Stephens RJ, Gower NH, Milroy R, Parmar MKB, et al. Chemotherapy for patients with nonsmall cell lung cancer: the surgical setting of the Big Lung Trial. European Journal of Cardio-Thoracic Surgery 2004;26: 173-82.

\section{A14 CALGB 9633 \{published and unpublished data}

Strauss GM, Herndon JE 2nd, Maddaus MA, Johnstone DW, Johnson EA, Harpole DH, et al. Adjuvant paclitaxel plus carboplatin compared with observation in stage IB non-small-cell lung cancer: CALGB 9633 with the Cancer and Leukemia Group B, Radiation Therapy Oncology Group, and North Central Cancer Treatment Group Study Groups. Journal of Clinical Oncology 2008;26(31):5043-51.

\section{A15 LCSG 801 \{published and unpublished data\}}

Feld R, Rubinstein L, Thomas PA. Adjuvant chemotherapy with cyclophosphamide, doxorubicin and cisplatin in patients with completely resected stage I non-small-cell lung cancer. Journal of the National Cancer Institute 1993;85(4): 299-306.

A16 FLCSG 1 \{published and unpublished data\} Niiranen A, Niitamo-Korhonen S, Kouri M, Assendelft A, Mattson K, Pyrhönen S. Adjuvant chemotherapy after radical surgery for non-small cell lung cancer: A randomized study. Journal of Clinical Oncology 1992;10(12):1927-32.

A17 LCSG 853 \{published and unpublished data\}

Figlin RA, Piantodosi S. A phase 3 randomized trial of immediate combination chemotherapy vs delayed combination chemotherapy in patients with completely resected stage II and III non-small cell carcinoma of the lung. Chest 1994;106(Suppl 6):310S-2S.

A18 BLT3 \{published and unpublished data\} Waller D, Peake MD, Stephens RJ, Gower NH, Milroy R, Parmar MKB, et al. Chemotherapy for patients with nonsmall cell lung cancer: the surgical setting of the Big Lung Trial. European Journal of Cardio-Thoracic Surgery 2004;26: 173-82.

A19 SGACLC ACTLC1 \{published and unpublished data\} Study Group for Adjuvant Chemotherapy for Lung Cancer. A randomised controlled trial of postoperative adjuvant chemotherapy in non-small cell lung cancer (in Japanese). Hai-gan 1992;32:481-6.

A20 OLCSG1c \{published and unpublished data\} Sawamura K, Mori T, Doi O, Yasumitsu T, Kawahara O, Kuwabara M, et al. A prospective randomized controlled study of the postoperative adjuvant therapy for non-small cell lung cancer. Lung Cancer 1988;4:A166.

A21 SGACLC ACTLC2 \{published and unpublished data\} Study Group for Adjuvant Chemotherapy for Lung Cancer. A randomized trial of postoperative adjuvant chemotherapy in non-small cell lung cancer (the second cooperative study) European Journal of Surgical Oncology 1995;21(1):69-77.

A22 WJSG $2(1+3)$ \{published and unpublished data\} Teramatsu T, Society of adjuvant chemotherapy for lung cancer surgery in West Japan. Assessment of postoperative adjuvant chemotherapy on non-small cell lung cancer (abstract). Lung Cancer 1991;7(Suppl):124.

* Wada H, Hitomi S, Takashi T, West Japan Study Group for Lung Cancer Surgery. Adjuvant chemotherapy after complete resection in non-small cell lung cancer (full publication). Journal of Clinical Oncology 1996;14: 1048-54. 
A23 WJSG3 \{published and unpublished data\}

Wada H, Miyahara R, Tanaka F, Hitomi S, West Japan Study Group for Lung Cancer Surgery. Post-operative adjuvant chemotherapy with PVM (cisplatin + vindesine + mitomycin c) and UFT (uracil and tegaful) in resected stage I-II NSCLC (non-small cell lung cancer): a randomised clinical trial. European Journal of Cardio-Thoracic Surgery 1999;15:438-43.

A24 Xu \{published and unpublished data\} Xu G, Rong T, Lin P. Adjuvant chemotherapy following radical surgery for non-small cell lung cancer: a randomized study. Zhonghua Zhong Liu Za Zhi 1998;20(3):228-30.

A25 ACTLC4a \{published and unpublished data\} Imaizumi M. Postoperative adjuvant cisplatin, vindesine, plus uracil-tegafur chemotherapy increased survival of patients with completely resected p-stage I non-small cell lung cancer. Lung Cancer 2005;49:85-94.

A26 OLCSG2b \{published and unpublished data\} Nakagawa K, Tada H, Akash iA, Yasumitsu T, Iuchi K, Taki $\mathrm{T}$, et al. Randomised study of adjuvant chemotherapy for completely resected p stage I-IIIa non-small cell lung cancer. British Journal of Cancer 2006;95:817-21.

A27 OLCSG1b \{published and unpublished data\} Sawamura K, Mori T, Doi O, Yasumitsu T, Kuwahara O, Kuwabara M, et al. A prospective randomized controlled study of the postoperative adjuvant therapy for non-small cell lung cancer. Lung Cancer 1988;4:A166.

A28 OLCSG1a \{published and unpublished data\} Sawamura K, Mori T, Doi O, Yasumitsu T, Kuwahara O, Kuwabara M, et al. A prospective randomized controlled study of the postoperative adjuvant therapy for non-small cell lung cancer. Lung Cancer 1988;4:A166.

A29 WJSG2 (2+3) \{published and unpublished data\} Wada H, Hitomi S, Takashi T, : West Japan Study Group for Lung Cancer Surgery. Adjuvant chemotherapy after complete resection in non-small cell lung cancer. Journal of Clinical Oncology 1996;14:1048-54.

A30 WJSG4 \{published and unpublished data\} Nakagawa M, Tanaka F, Tsubota N, Ohta M, Takao $\mathrm{M}$, Wada $\mathrm{H}$. A randomised phase III trial of adjuvant chemotherapy with UFT for completely resected pathological stage I non-small cell lung cancer: the West Japan Study Group for Lung Cancer Surgery (WJSG) - the 4th study. Annals of Oncology 2005;16:75-80.

A31 NJSGLCS \{published and unpublished data\} Endo C, Saitoi Y, Iwanawi H, Tsushima T, Imai T, Kawamura M, et al. A randomized trial of postoperative UFT in p stage I, II non-small cell lung cancer: North-East Japan Study Group for Lung Cancer Surgery. Lung Cancer 2003;40:181-6.

A32 OLCSG2a \{published and unpublished data\}

Nakagawa K, Tada H, Akash iA, Yasumitsu T, Iuchi K, Taki $\mathrm{T}$, et al. Randomised study of adjuvant chemotherapy for completely resected p stage I-IIIa non-small cell lung cancer. British Journal of Cancer 2006;95:817-21.
A33 ACTLC4b \{published and unpublished data\}

Imaizumi M. Postoperative adjuvant cisplatin, vindesine, plus uracil-tegafur chemotherapy increased survival of patients with completely resected p-stage I non-small cell lung cancer. Lung Cancer 2005;49:85-94.

A34 JLCRG \{published and unpublished data\}

Kato H, Ichinose Y, Ohta M, Hata E, Tsubota N, Tada H, et al. A randomised trial of adjuvant chemotherapy with uracil-tegafur for adenocarcinoma of the lung. New England Journal of Medicine 2004;350(17):1713-21.

B01 MSKCC 80-53 \{published and unpublished data\} Pisters KMW, Kris MG, Gralla RT, Hilaris B, McCormack PM, Bains MS. Randomized trial comparing post-operative chemotherapy with vindesine and cisplatin plus thoracic irradiation with irradiation alone in stage III (N2) nonsmall cell lung cancer. Journal of Surgical Oncology 1994;56: 236-241.

B02 GETCB $01 C B 82$ \{published and unpublished data\} Dautzenberg B, Chastang C, Arriagada R, Le Chevalier T, Belpomme D, Hurdebourcq M, et al. Adjuvant radiotherapy versus combined sequential chemotherapy followed by radiotherapy in the treatment of resected nonsmall cell lung cancer. Cancer 1995;76:779-86.

B03 EORTC 08861 \{unpublished data only\} EORTC Lung Cancer Cooperative Group. Phase III randomized trial of adjuvant radiotherapy vs radiotherapy plus chemotherapy with DDP/VDS vs no adjuvant therapy in patients with completely resected non-small cell lung cancer.

B04 MDA DM 87045 \{unpublished data only\} MD Anderson Cancer Centre. Phase III randomized comparison of chest irradiation vs combination chemotherapy with cyclophosphamide/etoposide/cisplatine (CEP) followed by chest irradiation in patients with partially resected stage II/III limited non small cell lung cancer.

B05 INT 0115 \{published and unpublished data\} Keller SM, Adak S, Wagner H, Herskovic A, Komaki R, Brookes BJ, et al. Postoperative adjuvant therapy in patients with stage II or IIIa non-small cell lung cancer. New England Journal of Medicine 2000;343:1217-22.

B06 ALPI2 \{published and unpublished data\} Scagliotti GV, Fossati R, Torri V, Crinò L, Giaccone G, Silvano G, et al. Randomized study of adjuvant chemotherapy for completely resected stage I, II or IIIa non-small cell lung cancer. Journal of the National Cancer Institute 2003;95(19):1453-61.

B07 IALT3 \{published and unpublished data\} Arriagada R, Dunant A, Pignon J-P, Bergman B, Chabowski $M$, Grunenwald D, et al. Long-term results of the International Adjuvant Lung Cancer Trial evaluating adjuvant cisplatin-based chemotherapy in resected lung cancer. Journal of Clinical Oncology 2010;28:35-42. The International Adjuvant Lung Cancer Trial Collaborative Group. Cisplatin-based adjuvant chemotherapy in patients with completely resected non-small cell lung cancer. New England Journal of Medicine 2004;350:351-60. 
B08 BLT4 \{published and unpublished data\}

Waller D, Peake MD, Stephens RJ, Gower NH, Milroy R, Parmar MKB, et al. Chemotherapy for patients with nonsmall cell lung cancer: the surgical setting of the Big Lung Trial. European Journal of Cardio-Thoracic Surgery 2004;26: $173-82$.

B09 ANITA2 \{published and unpublished data\} Douillard JY, Rosell R, De Lena M, Carpagnano F, Ramlau $\mathrm{R}$, Gonzales-Larriba JL, et al. Adjuvant vinorelbine plus cisplatin versus observation in patients with completely resected stage IB-IIIA non-small-cell lung cancer (Adjuvant Navelbine International Trialist Association [ANITA]): a randomised controlled trial. Lancet Oncology 2006;7: 719-27.

B10 IALT4 \{published and unpublished data\} Arriagada R, Dunant A, Pignon J-P, Bergman B, Chabowski $\mathrm{M}$, Grunenwald D, et al. Long-term results of the International Adjuvant Lung Cancer Trial evaluating adjuvant cisplatin-based chemotherapy in resected lung cancer. Journal of Clinical Oncology 2010;28:35-42. The International Adjuvant Lung Cancer Trial Collaborative Group. Cisplatin-based adjuvant chemotherapy in patients with completely resected non-small cell lung cancer. New England Journal of Medicine 2004;350:351-60.

B11 LCSG 791 \{published and unpublished data\}

Lad T. The comparison of CAP chemotherapy and radiotherapy to radiotherapy alone for resected lung cancer with positive margin or involved highest sampled paratracael node (stage IIIa). Chest 1994;106(6):303S.

* Lad T, Rubinstein L, Sadeghi A. The benefit of adjuvant treatment for resected locally advanced non-small cell lung cancer. Journal of Clinical Oncology 1988;6:9-17.

B12 FLCSG 3 \{unpublished data only\}

Niiranen, Kouri M, Pyrhonen S, Mattson K. Postsurgical radiotherapy versus postsurgical radiotherapy plus chemotherapy for non-small cell lung cancer.

B13 OLCSG1d \{published and unpublished data\}

Sawamura K, Mori T, Doi O, Yasumitsu T, Kawahara O, Kuwabara M, et al. A prospective randomized controlled study of the postoperative adjuvant therapy for non-small cell lung cancer. Lung Cancer 1988;4:A166.

\section{References to studies excluded from this review}

Ayoub 1991 \{published data only\}

Ayoub J, Vigneault E, Hanley J, Duranceau A, Robidoux A, Pagé A, et al. The Montreal multicenter trial in operable non-small cell lung cancer (NSCLC): A multivariate analysis of the predictors of relapse. Proceedings of the American Society of Clinical Oncology 1991;10:247.

Clerici 1991 \{published data only\}

Clerici M, Barni S, Cantaluppi G, et al. Adjuvant chemotherapy in non-small cell lung cancer: a randomised trial. European Journal of Cancer 1991;27(Suppl 2):S173.

EORTC 08922 \{unpublished data only\}
Ichinose 1991 \{published data only\}

Ichinose Y, Hara N, Ohta M, Motohiro A, Kuda T, Aso H. Postoperative adjuvant chemotherapy in non-small cell lung cancer: Prognostic value of DNA ploidy and postrecurrent survival. Journal of Surgical Oncology 1991;46:15-20.

Kim 2003 \{published data only\}

Kim S-W, Suh CS, Lee G-W, Ryu M-H, Lee SD, Kim WS, et al. The number of tumor $(+) \mathrm{N} 2$ nodes as a prognostic factor in the patients with $\mathrm{N} 2$ disease non-small cell lung cancer after curative resection and postoperative thoracic radiotherapy. Lung Cancer 2003;41(Supplement 2):S152.

\section{NCCTG 852451 \{unpublished data only\}}

Ueda 2004 \{published data only\}

Ueda H, Sakada T, Kuwahara M, Motohiro A. A small randomized phase III single-center trial on postoperative UFT administration in patients with completely resected non-small cell lung cancer. Anti-Cancer Drugs 2004;15(1): 29-33.

Wang 2009 \{published data only\}

Wang S, Ou W, Sun H, Yang HX, Fang Q. Adjuvant chemotherapy in completely resected stage III-N2 nonsmall cell lung cancer. Proceedings of the American Society of Clinical Oncology 2009;27:A7563.

Wolf 2001 \{published data only\}

Wolf M, Müller H, Seifart U, Friedel G, Hruska D, Serke M, et al. Randomized phase III trial of adjuvant radiotherapy versus adjuvant chemotherapy followed by radiotherapy in patients with $\mathrm{N} 2$ positive non-small cell lung cancer (NSCLC). Proceedings of the American Society of Clinical Oncology 2001;20:311a.

Wu 2009 \{published data only\}

Wu Y, Yang X, Chen G, Zhong W, Ben X-S, Gu L, et al. Adjuvant docetaxel plus carboplatin compared with surgery only in patients with completely resected stage IB-IIIA nonsmall cell lung cancer: final results of CSLC201/TAX210 with Chinese Society of Lung Cancer. Journal of Thoracic Oncology 2009;4(9):S583-S584.

Zarogoulidis 1996 \{published data only\} Zarogoulidis K, Filippou K, Antonio C, Papagiannis A, Hatziapostolou P, Tsiagga P, et al. The impact of adjuvant chemotherapy on the survival of postoperative stage IIIa NSCLC patients. Proceedings of the 2nd International Congress on Lung Cancer. Crete. 1996:PO35.

\section{References to studies awaiting assessment}

\section{NATCH 2010 \{published data only\}}

Felip E, Rosell R, Maestre JA, Rodriguez-Paniagua JM, Moran T, Astudillo J, et al. Preoperative chemotherapy plus surgery versus surgery plus adjuvant chemotherapy versus surgery alone in early-stage non-small-cell lung cancer. Journal of Clinical Oncology 2010;28(19):3138-45.

\section{Zheng 2011 \{published data only\}}

Zheng S, Jiang S, Li H. Adjuvant chemotherapy following radical surgery for non-small cell lung cancer: a randomised 
study on 70 patients. Journal of Thoracic Oncology 2011;6(6 Suppl 2):S866.

\section{References to ongoing studies}

\section{CALGB 30506 \{unpublished data only\}}

CALGB 30506: Phase III randomised study of adjuvant chemotherapy versus observation in patients with early stage non-small cell lung cancer. Ongoing study March 2009.

\section{Additional references}

\section{American Cancer Society 2007}

American Cancer Society. Cancer Facts and Figures 2007. www.cancer.org/acs/groups/content/@nho/documents/ document/caff2007pwsecuredpdf.pdf (accessed in December 2009) 2007.

\section{Arriagada 2010}

Arriagada R, Dunant A, Pignon J-P, Bergman B, Chabowski $M$, Grunenwald D, et al. Long-term results of the International Adjuvant Lung Cancer Trial evaluating adjuvant cisplatin-based chemotherapy in resected lung cancer. Journal of Clinical Oncology 2010;28(1):35-42.

\section{Berghmans 2005}

Berghmans T, Paesmans M, Meert AP, Mascaux C, Lothaire P, Lafitte JJ, et al. Survival improvement in resectable nonsmall cell lung cancer with (neo)adjuvant chemotherapy: Results of a meta-analysis of the literature. Lung Cancer 2005;49(1):13-23.

Bria 2005

Bria E, Gralla RJ, Raftopoulous H, Ferretti G, Felici A, Nistico C. Does adjuvant chemotherapy improve survival in non-small cell lung cancer (NSCLC)? A pooled analysis of 6494 patients in 12 studies, examining survival and magnitude of benefit. Journal of Clinical Oncology 2005;23 (16S):7140.

\section{Butts 2010}

Butts CA, Ding K, Seymour L, Twumasi-Ankrah P, Graham B, Gandara D, et al. Randomised phase III trial of vinorelbine plus cisplatin compared with observation in completely resected stage Ib and II non-small cell lung cancer: Updated survival analysis of JBR-10. Journal of Clinical Oncology 2010;28(1):29-34.

\section{Datta 2003}

Datta D, Lahiri B. Preoperative evaluation of patients undergoing lung resection surgery. Chest 2003;123(6): 2096-103.

Fisher 2011

Fisher DJ, Copas AJ, Tierney JF, Parmar MKB. A critical review of methods for the assessment of patient-level interactions in individual patient data (IPD) meta-analysis of randomised trials, and guidance for practitioners. Journal of Clinical Epidemiology 2011;64(9):949-967.

\section{Hamada 2005}

Hamada C, Tanaka F, Ohta M, Fujimura S, Kodama $\mathrm{K}$, Imaizumi M, et al. Meta-analysis of postoperative adjuvant chemotherapy with tegafur-uracil in non-small cell lung cancer. Journal of Clinical Oncology 2005;23(22): 4999-5006.

\section{Higgins 2011}

Higgins JPT, Green S, editors. Cochrane Handbook for Systematic Reviews of Interventions. Cochrane Handbook for Systematic Reviews of Interventions - Version 5.0.1 (updated in September 2011). The Cochrane Collaboration, 2011. Available from www.cochrane-handbook.org.

\section{Hotta 2004}

Hotta K, Matsuo K, Ueoka H, Kiura K, Tabata M, Tanimoto M. Role of adjuvant chemotherapy in patients with resected non-small cell lung cancer: Reappraisal with a meta-analysis of randomised controlled trials. Journal of Clinical Oncology 2004;22(19):3860-7.

\section{IASLC 2009}

International Association for the Study of Lung Cancer. Staging Manual in Thoracic Oncology. 1st Edition. Orange Park, FL, USA: Editorial Rx Press, 2009.

\section{Lefebvre 2001}

Lefebvre C, Clarke MJ. Identifying randomised trials. In: Egger M, Smith GD, Altman DG editor(s). Systematic reviews in healthcare. 2nd Edition. London: BMJ Publishing Group, 2001:69-87.

\section{Lefebvre 2008}

Lefebvre C, Manheimer E, Glanville J, Cochrane Information Retrieval Methods Group. Searching for studies. In: Higgins JPT, Green S, Editors. Cochrane Handbook for Systematic Reviews of Interventions. The Cochrane Collaboration, 2008:95-150.

NSCLC Collaborative Group 1995

Non-Small Cell Lung Cancer Collaborative Group. Chemotherapy in non-small cell lung cancer: a metaanalysis using updated data on individual patients from 52 randomised clinical trials. BMJ 1995;311 (7010):899-909.

NSCLC Collaborative Group 2000

Non-Small Cell Lung Cancer Collaborative Group. Chemotherapy for non-small cell lung cancer. Cochrane Database of Systematic Reviews 2000, Issue 2. [DOI: 10.1002/14651858.CD002139]

\section{Parkin 2005}

Parkin DM, Bray F, Ferlay J, Pisani Paola. Global cancer statistics, 2002. CA: A Cancer Journal for Clinicians 2005; 55(2):74-108.

\section{Pignon 2008}

Pignon JP, Tribodet H, Scagliotti GV, Douillard JY, Shepherd FA, Stephens RJ, et al. Lung Adjuvant Cisplatin Evaluation: A pooled analysis by the LACE Collaborative Group. Journal of Clinical Oncology 2008;26(21):3552-9.

\section{Pisters 2007}

Pisters KM, Evans WK, Azzoli CG, Kris MG, Smith CA, Desch CE, et al. Cancer Care Ontario and American Society of Clinical Oncology adjuvant chemotherapy and adjuvant radiation therapy for stages I-IIIA resectable non small-cell lung cancer guideline. Journal of Clinical Oncology 2007;25(34):5506-18. 


\section{PORT 1998}

PORT Meta-analysis Trialists Group. Postoperative radiotherapy in non-small-cell lung cancer: systematic review and meta-analysis of individual patient data from nine randomised controlled trials. Lancet 1998;352(9124): 257-63.

PORT 2005

PORT Meta-analysis Trialists Group. Postoperative radiotherapy for non-small cell lung cancer. Cochrane Database of Systematic Reviews 2005, Issue 2. [DOI: 10.1002/14651858.CD002142.pub2]

RevMan 2014

The Cochrane Collaboration. Review Manager (RevMan). Computer Program. 5.3.5 Copenhagen: the Nordic Cochrane Centre. The Cochrane Collaboration, 2014.

\section{Schemper 1996}

Schemper M, Smith TL. A note on quantifying follow-up in studies of failure time. Controlled Clinical Trials 1996;17 (4):343-6.

\section{Sedrakyan 2004}

Sedrakyan A, van Der Meulen J, O'Byrne K, Prendiville J, Hill J, Treasure T. Postoperative chemotherapy for nonsmall cell lung cancer: A systematic review and meta- analysis. Journal of Thoracic and Cardiovascular Surgery 2004;128(3):414-9.

\section{Sekine 2008}

Sekine I, Yamamoto N, Nisho K, Saijo N. Emerging ethnic differences in lung cancer therapy. British Journal of Cancer 2008;99(11):1757-62.

Toyooka 2009

Toyooka S, Hotta K, Nakamura H, Nakata M, Tada H, Yamashita M, et al. A multicenter, phase III study of carboplatin/paclitaxel, versus oral uracil-tegafur as the adjuvant chemotherapy in resected non-small cell lung cancer (NSCLC): planned interim analyses. Proceedings of the American Society of Clinical Oncology 2009;27(15): A7560.

\section{References to other published versions of this review}

NSCLC Meta-analysis Collaborative Group 2010

Non-Small Cell Lung Cancer Collaborative Group. Adjuvant chemotherapy, with or without postopertative radiotherapy, in operable non-small cell lung cancer: two meta-analyses of individual patient data. Lancet 2010;375 (9722):1267-77.

* Indicates the major publication for the study 


\section{CHARACTERISTICS OF STUDIES}

\section{Characteristics of included studies [ordered by study ID]}

\section{A01 IPCR, Chiba}

\begin{tabular}{|c|c|c|}
\hline Methods & \multicolumn{2}{|l|}{ RCT: 1985 to 1991} \\
\hline Participants & \multicolumn{2}{|l|}{$\begin{array}{l}29 \text { patients } \\
\text { Stage NK }\end{array}$} \\
\hline Interventions & \multicolumn{2}{|c|}{$\begin{array}{l}\text { surgery vs surgery + chemotherapy } \\
\text { cisplatin } 80 \mathrm{mg} / \mathrm{m}^{2} \\
\text { vindesine } 3 \mathrm{mg} / \mathrm{m}^{2} \\
\text { mitomycin c } 8 \mathrm{mg} / \mathrm{m}^{2} \\
\text { Complete and incomplete resection }\end{array}$} \\
\hline Outcomes & \multicolumn{2}{|l|}{ Overall survival } \\
\hline Notes & \multicolumn{2}{|c|}{$>2$ cycles of chemotherapy } \\
\hline \multicolumn{3}{|l|}{ Risk of bias } \\
\hline Bias & Authors' judgement & Support for judgement \\
\hline $\begin{array}{l}\text { Random sequence generation (selection } \\
\text { bias) }\end{array}$ & Low risk & $\begin{array}{l}\text { Data checks on IPD provided suggest adequate sequence gener- } \\
\text { ation }\end{array}$ \\
\hline Allocation concealment (selection bias) & Low risk & Sealed envelope \\
\hline Selective reporting (reporting bias) & Low risk & IPD supplied for outcomes \\
\hline $\begin{array}{l}\text { Blinding of participants and personnel } \\
\text { (performance bias) } \\
\text { All outcomes }\end{array}$ & Low risk & $\begin{array}{l}\text { Trial not blinded due to nature of intervention, outcome not } \\
\text { likely to be influenced by lack of blinding }\end{array}$ \\
\hline $\begin{array}{l}\text { Blinding of outcome assessment (detection } \\
\text { bias) } \\
\text { All outcomes }\end{array}$ & Low risk & $\begin{array}{l}\text { Trial not blinded due to nature of intervention, primary outcome } \\
\text { not likely to be influenced by lack of blinding }\end{array}$ \\
\hline
\end{tabular}

\section{A02 JLCSSG}

\begin{tabular}{ll}
\hline Methods & RCT: 1986 to 1988 \\
\hline Participants & $\begin{array}{l}209 \text { patients } \\
\text { Stage III }\end{array}$
\end{tabular}




\section{A02 JLCSSG (Continued)}

\begin{tabular}{|c|c|c|}
\hline Interventions & \multicolumn{2}{|c|}{$\begin{array}{l}\text { surgery vs surgery + chemotherapy } \\
2-3 \text { cycles of chemotherapy } \\
\text { cisplatin } 80 \mathrm{mg} / \mathrm{m}^{2} \\
\text { vindesine } 6 \mathrm{mg} / \mathrm{m}^{2}\end{array}$} \\
\hline Outcomes & \multicolumn{2}{|l|}{ Overall survival } \\
\hline \multicolumn{3}{|l|}{ Notes } \\
\hline \multicolumn{3}{|l|}{ Risk of bias } \\
\hline Bias & Authors' judgement & Support for judgement \\
\hline $\begin{array}{l}\text { Random sequence generation (selection } \\
\text { bias) }\end{array}$ & Low risk & $\begin{array}{l}\text { Data checks on IPD provided suggest adequate sequence gener- } \\
\text { ation }\end{array}$ \\
\hline Allocation concealment (selection bias) & Low risk & Permuted block randomisation \\
\hline Selective reporting (reporting bias) & Low risk & IPD supplied for outcomes \\
\hline $\begin{array}{l}\text { Blinding of participants and personnel } \\
\text { (performance bias) } \\
\text { All outcomes }\end{array}$ & Low risk & $\begin{array}{l}\text { Trial not blinded due to nature of intervention, outcome not } \\
\text { likely to be influenced by lack of blinding }\end{array}$ \\
\hline $\begin{array}{l}\text { Blinding of outcome assessment (detection } \\
\text { bias) } \\
\text { All outcomes }\end{array}$ & Low risk & $\begin{array}{l}\text { Trial not blinded due to nature of intervention, primary outcome } \\
\text { not likely to be influenced by lack of blinding }\end{array}$ \\
\hline
\end{tabular}

A03 Mineo

\begin{tabular}{ll}
\hline Methods & RCT: 1988 to 1994 \\
\hline Participants & $\begin{array}{l}66 \text { patients } \\
\text { Stage IB }\end{array}$ \\
\hline Interventions & $\begin{array}{l}\text { surgery vs surgery }+ \text { chemotherapy } \\
6 \text { cycles of chemotherapy } \\
\text { cisplatin } 100 \mathrm{mg} / \mathrm{m}^{2} \text { etoposide } 120 \mathrm{mg} / \mathrm{m}^{2} \\
\text { Complete resection }\end{array}$ \\
\hline Outcomes & $\begin{array}{l}\text { Overall survival } \\
5 \text { year recurrence-free survival } \\
\text { Recurrence rates } \\
\text { Cause of death }\end{array}$ \\
\hline Notes & $\begin{array}{l}140 \text { patients in trial, only } 66 \text { reported at time of data collection, therefore only } 66 \text { patients } \\
\text { included }\end{array}$ \\
\hline
\end{tabular}


A03 Mineo (Continued)

\section{Risk of bias}

\begin{tabular}{|c|c|c|}
\hline Bias & Authors' judgement & Support for judgement \\
\hline $\begin{array}{l}\text { Random sequence generation (selection } \\
\text { bias) }\end{array}$ & Low risk & $\begin{array}{l}\text { Data checks on IPD provided suggest adequate sequence gener- } \\
\text { ation }\end{array}$ \\
\hline Allocation concealment (selection bias) & Low risk & Central computer randomisation \\
\hline Selective reporting (reporting bias) & Low risk & IPD supplied for outcomes \\
\hline $\begin{array}{l}\text { Blinding of participants and personnel } \\
\text { (performance bias) } \\
\text { All outcomes }\end{array}$ & Low risk & $\begin{array}{l}\text { Trial not blinded due to nature of intervention, outcome not } \\
\text { likely to be influenced by lack of blinding }\end{array}$ \\
\hline $\begin{array}{l}\text { Blinding of outcome assessment (detection } \\
\text { bias) } \\
\text { All outcomes }\end{array}$ & Low risk & $\begin{array}{l}\text { Trial not blinded due to nature of intervention, primary outcome } \\
\text { not likely to be influenced by lack of blinding }\end{array}$ \\
\hline
\end{tabular}

\section{A04 Park1}

\begin{tabular}{|c|c|}
\hline Methods & RCT: 1989 to 1998 \\
\hline Participants & $\begin{array}{l}118 \text { patients } \\
\text { Stage I }\end{array}$ \\
\hline Interventions & $\begin{array}{l}\text { surgery vs surgery }+ \text { chemotherapy } \\
3-4 \text { cycles of chemotherapy } \\
\text { mitomycin c } 10 \mathrm{mg} / \mathrm{m}^{2} \\
\text { vinblastin } 6 \mathrm{mg} / \mathrm{m}^{2} \\
\text { cisplatin } 100 \mathrm{mg} / \mathrm{m}^{2} \\
\text { Complete resection }\end{array}$ \\
\hline Outcomes & $\begin{array}{l}\text { Overall survival } \\
\text { Recurrence-free survival } \\
\text { Death from any cause } \\
\text { Toxicity }\end{array}$ \\
\hline Notes & \\
\hline
\end{tabular}

\section{Risk of bias}

Bias

Random sequence generation (selection Low risk bias)

Low risk
Allocation concealment (selection bias)

Authors' judgement Support for judgement

Adjuvant chemotherapy for resected early-stage non-small cell lung cancer (Review)

Copyright $\odot 2015$ The Cochrane Collaboration. Published by John Wiley \& Sons, Ltd.

Data checks on IPD provided suggest adequate sequence generation

Central randomisation 
A04 Park1 (Continued)

\begin{tabular}{l|l|l}
\hline Selective reporting (reporting bias) & Low risk & IPD supplied for outcomes \\
\hline $\begin{array}{l}\text { Blinding of participants and personnel } \\
\text { (performance bias) } \\
\text { All outcomes }\end{array}$ & Low risk & $\begin{array}{l}\text { Trial not blinded due to nature of intervention, outcome not } \\
\text { likely to be influenced by lack of blinding }\end{array}$ \\
\hline $\begin{array}{l}\text { Blinding of outcome assessment (detection } \\
\text { bias) } \\
\text { All outcomes }\end{array}$ & Low risk & $\begin{array}{l}\text { Trial not blinded due to nature of intervention, primary outcome } \\
\text { not likely to be influenced by lack of blinding }\end{array}$ \\
\hline
\end{tabular}

\section{A05 Park2}

\begin{tabular}{|c|c|}
\hline Methods & RCT: 1989 to 1998 \\
\hline Participants & $\begin{array}{l}108 \text { patients } \\
\text { Stage IIIA }\end{array}$ \\
\hline Interventions & $\begin{array}{l}\text { surgery vs surgery + chemotherapy } \\
3-4 \text { cycles of chemotherapy } \\
\text { cisplatin } 100 \mathrm{mg} / \mathrm{m}^{2} \\
\text { mitomycin c } 10 \mathrm{mg} / \mathrm{m}^{2} \\
\text { vinblastine } 6 \mathrm{mg} / \mathrm{m}^{2} \\
\text { Complete resection }\end{array}$ \\
\hline Outcomes & $\begin{array}{l}\text { Overall survival } \\
\text { Recurrence-free survival }\end{array}$ \\
\hline Notes & 2 arms of a 3 -arm trial \\
\hline
\end{tabular}

\section{Risk of bias}

\section{Bias}

\section{Authors' judgement Support for judgement}

Random sequence generation (selection Low risk bias)

Data checks on IPD provided suggest adequate sequence generation

\begin{tabular}{lll} 
Allocation concealment (selection bias) & Low risk & Central randomisation \\
\hline Selective reporting (reporting bias) & Low risk & IPD supplied for outcomes \\
\hline
\end{tabular}

Blinding of participants and personnel Low risk (performance bias)

Trial not blinded due to nature of intervention, outcome not All outcomes

likely to be influenced by lack of blinding

Blinding of outcome assessment (detection Low risk bias)

Trial not blinded due to nature of intervention, primary outcome

All outcomes not likely to be influenced by lack of blinding 
A06 ALPI1

Methods

RCT: 1994 to 1999

Participants

618 patients

Stage I-IIIA

\begin{tabular}{ll} 
Interventions & $\begin{array}{l}\text { surgery vs surgery }+ \text { chemotherapy } \\
3 \text { cycles of chemotherapy } \\
\text { cisplatin } 100 \mathrm{mg} / \mathrm{m}^{2} \\
\text { vindesine } 6 \mathrm{mg} / \mathrm{m}^{2} \\
\text { mitomycin } 8 \mathrm{mg} / \mathrm{m}^{2} \\
\text { Complete resection }\end{array}$ \\
\hline Outcomes & $\begin{array}{l}\text { Overall survival } \\
\text { Recurrence-free survival } \\
\text { Toxicity }\end{array}$ \\
\hline Notes & $\begin{array}{l}1088 \text { patients analysed, } 470 \text { received RT, only } 618 \text { patients relevant to this trial compar- } \\
\text { ison }\end{array}$
\end{tabular}

Risk of bias

\begin{tabular}{l|l|l}
\hline Bias & Authors judgement & Support for judgement \\
\hline $\begin{array}{l}\text { Random sequence generation (selection } \\
\text { bias) }\end{array}$ & Low risk & $\begin{array}{l}\text { Data checks on IPD provided suggest adequate sequence gener- } \\
\text { ation }\end{array}$ \\
\hline $\begin{array}{l}\text { Allocation concealment (selection bias) } \\
\text { Selective reporting (reporting bias) }\end{array}$ & Low risk & Central randomisation \\
\hline $\begin{array}{l}\text { Blinding of participants and personnel } \\
\text { (performance bias) } \\
\text { All outcomes }\end{array}$ & Low risk & IPD supplied for outcomes \\
\hline $\begin{array}{l}\text { Blinding of outcome assessment (detection } \\
\text { bias) } \\
\text { All outcomes }\end{array}$ & Low risk & $\begin{array}{l}\text { Trial not blinded due to nature of intervention, outcome not } \\
\text { likely to be influenced by lack of blinding }\end{array}$ \\
\hline
\end{tabular}

A07 IALT1

$\begin{array}{ll}\text { Methods } & \text { RCT: } 1995 \text { to } 2001\end{array}$

Participants 1001 patients

Stage I-III

Interventions

surgery vs surgery + chemotherapy

3 or 4 cycles of chemotherapy

cisplatin 80,100 or $120 \mathrm{mg} / \mathrm{m}^{2}$

and vindesine $3 \mathrm{mg} / \mathrm{m}^{2}$

Adjuvant chemotherapy for resected early-stage non-small cell lung cancer (Review)

Copyright $\odot 2015$ The Cochrane Collaboration. Published by John Wiley \& Sons, Ltd. 


\begin{tabular}{|c|c|c|}
\hline & \multicolumn{2}{|c|}{$\begin{array}{l}\text { or vinblastine } 8 \mathrm{mg} / \mathrm{m}^{2} \\
\text { or etoposide } 300 \mathrm{mg} / \mathrm{m}^{2} \\
\text { Complete resection }\end{array}$} \\
\hline Outcomes & \multicolumn{2}{|c|}{$\begin{array}{l}\text { Overall survival } \\
\text { Recurrence-free survival } \\
\text { Causes of death }\end{array}$} \\
\hline Notes & \multicolumn{2}{|c|}{1867 patients randomised to trial, 1001 patients in this trial comparison } \\
\hline \multicolumn{3}{|l|}{ Risk of bias } \\
\hline Bias & Authors' judgement & Support for judgement \\
\hline $\begin{array}{l}\text { Random sequence generation (selection } \\
\text { bias) }\end{array}$ & Low risk & $\begin{array}{l}\text { Data checks on IPD provided suggest adequate sequence gener- } \\
\text { ation }\end{array}$ \\
\hline Allocation concealment (selection bias) & Low risk & Central randomisation \\
\hline Selective reporting (reporting bias) & Low risk & IPD supplied for outcomes \\
\hline $\begin{array}{l}\text { Blinding of participants and personnel } \\
\text { (performance bias) } \\
\text { All outcomes }\end{array}$ & Low risk & $\begin{array}{l}\text { Trial not blinded due to nature of intervention, outcome not } \\
\text { likely to be influenced by lack of blinding }\end{array}$ \\
\hline $\begin{array}{l}\text { Blinding of outcome assessment (detection } \\
\text { bias) } \\
\text { All outcomes }\end{array}$ & Low risk & $\begin{array}{l}\text { Trial not blinded due to nature of intervention, primary outcome } \\
\text { not likely to be influenced by lack of blinding }\end{array}$ \\
\hline
\end{tabular}

\section{A08 BLT1}

Methods

RCT: 1995 to 2001

\begin{tabular}{ll}
\hline Participants & $\begin{array}{l}136 \text { patients } \\
\text { Stage I-III }\end{array}$ \\
\hline
\end{tabular}

\begin{tabular}{|c|c|}
\hline Interventions & $\begin{array}{l}\text { surgery vs surgery }+ \text { chemotherapy } \\
3 \text { cycles of chemotherapy } \\
\text { cisplatin } 50 \mathrm{mg} / \mathrm{m}^{2} \\
\text { mitomycin } 6 \mathrm{mg} / \mathrm{m}^{2} \\
\text { vinblastine } 6 \mathrm{mg} / \mathrm{m}^{2} \\
\text { or } \\
\text { cisplatin } 80 \\
\text { vindestine } 6 \\
\text { Complete resection }\end{array}$ \\
\hline
\end{tabular}

Outcomes

Overall survival 


\section{A08 BLT1 (Continued)}

Notes

381 patients randomised in surgical setting, 136 relevant to this trial comparison

\section{Risk of bias}

\begin{tabular}{l|l|l}
\hline Bias & Authors' judgement & Support for judgement \\
\hline $\begin{array}{l}\text { Random sequence generation (selection } \\
\text { bias) }\end{array}$ & Low risk & $\begin{array}{l}\text { Data checks on IPD provided suggest adequate sequence gener- } \\
\text { ation }\end{array}$ \\
\hline $\begin{array}{l}\text { Allocation concealment (selection bias) } \\
\text { Selective reporting (reporting bias) }\end{array}$ & Low risk & Central randomisation \\
\hline $\begin{array}{l}\text { Blinding of participants and personnel } \\
\text { (performance bias) } \\
\text { All outcomes }\end{array}$ & Low risk & IPD supplied for outcomes \\
\hline $\begin{array}{l}\text { Blinding of outcome assessment (detection } \\
\text { bias) } \\
\text { All outcomes }\end{array}$ & Low risk & $\begin{array}{l}\text { Trial not blinded due to nature of intervention, outcome not } \\
\text { likely to be influenced by lack of blinding }\end{array}$ \\
\hline
\end{tabular}

\section{A09 JCOG 9304}

\begin{tabular}{ll}
\hline Methods & RCT: 1994 to 1999 \\
\hline Participants & $\begin{array}{l}119 \text { patients } \\
\text { Stage I-III }\end{array}$ \\
\hline Interventions & $\begin{array}{l}\text { surgery vs surgery }+ \text { chemotherapy } \\
\text { cycles of chemotherapy } \\
\text { cisplatin } 80 \mathrm{mg} / \mathrm{m}^{2} \\
\text { vindesine } 3 \mathrm{mg} / \mathrm{m}^{2} \\
\text { Complete and incomplete resection }\end{array}$ \\
\hline Outcomes & Overall survival \\
\hline Notes & \\
\hline
\end{tabular}

\section{Risk of bias}

Bias Authors' judgement Support for judgement

Random sequence generation (selection Low risk bias)

Data checks on IPD provided suggest adequate sequence generation

Allocation concealment (selection bias) $\quad$ Low risk $\quad$ Randomisation by blocks within each institution 
A09 JCOG 9304 (Continued)

\begin{tabular}{l|l|l}
\hline Selective reporting (reporting bias) & Low risk & IPD supplied for outcomes \\
\hline $\begin{array}{l}\text { Blinding of participants and personnel } \\
\text { (performance bias) } \\
\text { All outcomes }\end{array}$ & Low risk & $\begin{array}{l}\text { Trial not blinded due to nature of intervention, outcome not } \\
\text { likely to be influenced by lack of blinding }\end{array}$ \\
\hline $\begin{array}{l}\text { Blinding of outcome assessment (detection } \\
\text { bias) } \\
\text { All outcomes }\end{array}$ & Low risk & $\begin{array}{l}\text { Trial not blinded due to nature of intervention, primary outcome } \\
\text { not likely to be influenced by lack of blinding }\end{array}$ \\
\hline
\end{tabular}

\section{A10 ANITA1}

Methods

Participants

Stage IB-IIIA

463 patients
RCT: 1994 to 2000

surgery vs surgery + chemotherapy

4 cycles of chemotherapy

cisplatin $100 \mathrm{mg} / \mathrm{m}^{2}$

vinorelbine $180 \mathrm{mg} / \mathrm{m}^{2}$

Complete resection
Outcomes

Notes
Overall survival

840 patients randomised in trial, 436 patients relevant to this trial comparison

\section{Risk of bias}

\begin{tabular}{l|l|l} 
Bias & Authors' judgement & Support for judgement \\
\hline $\begin{array}{l}\text { Random sequence generation (selection } \\
\text { bias) }\end{array}$ & Low risk & $\begin{array}{l}\text { Data checks on IPD provided suggest adequate sequence gener- } \\
\text { ation }\end{array}$ \\
\hline $\begin{array}{l}\text { Allocation concealment (selection bias) } \\
\text { Selective reporting (reporting bias) }\end{array}$ & Low risk & Lentral computer randomisation \\
\hline $\begin{array}{l}\text { Blinding of participants and personnel } \\
\text { (performance bias) } \\
\text { All outcomes }\end{array}$ & Low risk & IPD supplied for outcomes \\
\hline $\begin{array}{l}\text { Blinding of outcome assessment (detection } \\
\text { bias) } \\
\text { All outcomes }\end{array}$ & Low risk & $\begin{array}{l}\text { Trial not blinded due to nature of intervention, outcome not } \\
\text { likely to be influenced by lack of blinding }\end{array}$ \\
\hline
\end{tabular}




\section{A11 JBR10}

\begin{tabular}{|c|c|c|}
\hline Methods & \multicolumn{2}{|l|}{ RCT: 1994 to 2001} \\
\hline Participants & \multicolumn{2}{|l|}{$\begin{array}{l}482 \text { patients } \\
\text { Stage IB-II }\end{array}$} \\
\hline Interventions & \multicolumn{2}{|c|}{$\begin{array}{l}\text { surgery vs surgery + chemotherapy } \\
4 \text { cycles of chemotherapy } \\
\text { cisplatin } 50 \mathrm{mg} / \mathrm{m}^{2} \\
\text { vinorelbine } 25 \mathrm{mg} / \mathrm{m}^{2} \text { (initial patients received } 30 \mathrm{mg} / \mathrm{m}^{2} \text { ) } \\
\text { Complete resection }\end{array}$} \\
\hline Outcomes & \multicolumn{2}{|c|}{$\begin{array}{l}\text { Overall survival } \\
\text { Recurrence-free survival }\end{array}$} \\
\hline Notes & \multicolumn{2}{|c|}{ Updated survival published in 2010, data included here is as published in 2005} \\
\hline \multicolumn{3}{|l|}{ Risk of bias } \\
\hline Bias & Authors' judgement & Support for judgement \\
\hline $\begin{array}{l}\text { Random sequence generation (selection } \\
\text { bias) }\end{array}$ & Low risk & $\begin{array}{l}\text { Data checks on IPD provided suggest adequate sequence gener- } \\
\text { ation }\end{array}$ \\
\hline Allocation concealment (selection bias) & Low risk & Central randomisation \\
\hline Selective reporting (reporting bias) & Low risk & IPD supplied for outcomes \\
\hline $\begin{array}{l}\text { Blinding of participants and personnel } \\
\text { (performance bias) } \\
\text { All outcomes }\end{array}$ & Low risk & $\begin{array}{l}\text { Trial not blinded due to nature of intervention, outcome not } \\
\text { likely to be influenced by lack of blinding }\end{array}$ \\
\hline $\begin{array}{l}\text { Blinding of outcome assessment (detection } \\
\text { bias) } \\
\text { All outcomes }\end{array}$ & Low risk & $\begin{array}{l}\text { Trial not blinded due to nature of intervention, primary outcome } \\
\text { not likely to be influenced by lack of blinding }\end{array}$ \\
\hline
\end{tabular}

A12 IALT2

Methods

RCT 1995 to 2001

Participants

294 patients

Stage I-III

Interventions surgery vs surgery + chemotherapy

3 or 4 cycles of chemotherapy

cisplatin 80,100 or $120 \mathrm{mg} / \mathrm{m}^{2}$

vinorelbine $30 \mathrm{mg} / \mathrm{m}^{2}$

Complete resection 


\section{A12 IALT2 (Continued)}

\begin{tabular}{|c|c|c|}
\hline Outcomes & \multicolumn{2}{|l|}{$\begin{array}{l}\text { Overall survival } \\
\text { Recurrence-free survival } \\
\text { Causes of death }\end{array}$} \\
\hline Notes & \multicolumn{2}{|c|}{1867 patients randomised to trial, 294 patients in this trial comparison } \\
\hline \multicolumn{3}{|l|}{ Risk of bias } \\
\hline Bias & Authors' judgement & Support for judgement \\
\hline $\begin{array}{l}\text { Random sequence generation (selection } \\
\text { bias) }\end{array}$ & Low risk & $\begin{array}{l}\text { Data checks on IPD provided suggest adequate sequence gener- } \\
\text { ation }\end{array}$ \\
\hline Allocation concealment (selection bias) & Low risk & Central randomisation \\
\hline Selective reporting (reporting bias) & Low risk & IPD supplied for outcomes \\
\hline $\begin{array}{l}\text { Blinding of participants and personnel } \\
\text { (performance bias) } \\
\text { All outcomes }\end{array}$ & Low risk & $\begin{array}{l}\text { Trial not blinded due to nature of intervention, outcome not } \\
\text { likely to be influenced by lack of blinding }\end{array}$ \\
\hline $\begin{array}{l}\text { Blinding of outcome assessment (detection } \\
\text { bias) } \\
\text { All outcomes }\end{array}$ & Low risk & $\begin{array}{l}\text { Trial not blinded due to nature of intervention, primary outcome } \\
\text { not likely to be influenced by lack of blinding }\end{array}$ \\
\hline
\end{tabular}

\section{A13 BLT2}

\begin{tabular}{l|l}
\hline Methods & RCT 1995 to 2001 \\
\hline Participants & $\begin{array}{l}65 \text { patients } \\
\text { Stage I-III }\end{array}$ \\
\hline Interventions & $\begin{array}{l}\text { surgery vs surgery }+ \text { chemotherapy } \\
\text { cycles of chemotherapy } \\
\text { cisplatin } 80 \mathrm{mg} / \mathrm{m}^{2} \\
\text { vinorelbine } 60 \mathrm{mg} / \mathrm{m}^{2} \\
\text { Complete resection }\end{array}$ \\
\hline Outcomes & Overall survival \\
\hline Notes & 381 patients randomised in surgical setting, 65 patients relevant to this trial comparison \\
\hline
\end{tabular}

\section{Risk of bias}

\section{Bias}

\section{Authors' judgement Support for judgement}

Random sequence generation (selection Low risk bias)
Data checks on IPD provided suggest adequate sequence generation 


\section{A13 BLT2 (Continued)}

\begin{tabular}{|c|c|c|}
\hline Allocation concealment (selection bias) & Low risk & Central randomisation \\
\hline Selective reporting (reporting bias) & Low risk & IPD supplied for outcomes \\
\hline $\begin{array}{l}\text { Blinding of participants and personnel } \\
\text { (performance bias) } \\
\text { All outcomes }\end{array}$ & Low risk & $\begin{array}{l}\text { Trial not blinded due to nature of intervention, outcome not } \\
\text { likely to be influenced by lack of blinding }\end{array}$ \\
\hline $\begin{array}{l}\text { Blinding of outcome assessment (detection } \\
\text { bias) } \\
\text { All outcomes }\end{array}$ & Low risk & $\begin{array}{l}\text { Trial not blinded due to nature of intervention, primary outcome } \\
\text { not likely to be influenced by lack of blinding }\end{array}$ \\
\hline
\end{tabular}

\section{A14 CALGB 9633}

\begin{tabular}{ll}
\hline Methods & RCT: 1996 to 2003 \\
\hline Participants & $\begin{array}{l}344 \text { patients } \\
\text { Stage IB }\end{array}$ \\
\hline Interventions & $\begin{array}{l}\text { surgery vs surgery }+ \text { chemotherapy } \\
\text { cycles of chemotherapy } \\
\text { carboplatin } 6 \mathrm{mg} / \mathrm{mL} \text { over } 45-60 \mathrm{~min} \\
\text { vinorelbine } 30 \mathrm{mg} / \mathrm{m}^{2} \\
\text { Complete resection }\end{array}$ \\
\hline Outcomes & Overall survival \\
\hline Notes & \\
\hline
\end{tabular}

\section{Risk of bias}

\begin{tabular}{|c|c|c|}
\hline Bias & Authors' judgement & Support for judgement \\
\hline $\begin{array}{l}\text { Random sequence generation (selection } \\
\text { bias) }\end{array}$ & Low risk & $\begin{array}{l}\text { Data checks on IPD provided suggest adequate sequence gener- } \\
\text { ation }\end{array}$ \\
\hline Allocation concealment (selection bias) & Low risk & Central randomisation \\
\hline Selective reporting (reporting bias) & Low risk & IPD supplied for outcomes \\
\hline $\begin{array}{l}\text { Blinding of participants and personnel } \\
\text { (performance bias) } \\
\text { All outcomes }\end{array}$ & Low risk & $\begin{array}{l}\text { Trial not blinded due to nature of intervention, outcome not } \\
\text { likely to be influenced by lack of blinding }\end{array}$ \\
\hline $\begin{array}{l}\text { Blinding of outcome assessment (detection } \\
\text { bias) } \\
\text { All outcomes }\end{array}$ & Low risk & $\begin{array}{l}\text { Trial not blinded due to nature of intervention, primary outcome } \\
\text { not likely to be influenced by lack of blinding }\end{array}$ \\
\hline
\end{tabular}


A15 LCSG 801

\begin{tabular}{|c|c|c|}
\hline Methods & \multicolumn{2}{|l|}{ RCT: 1980 to 1986} \\
\hline Participants & \multicolumn{2}{|l|}{$\begin{array}{l}283 \text { patients } \\
\text { Stage I }\end{array}$} \\
\hline Interventions & \multicolumn{2}{|c|}{$\begin{array}{l}\text { surgery vs surgery + chemotherapy } \\
4 \text { cycles of chemotherapy } \\
\text { cisplatin } 60 \mathrm{mg} / \mathrm{m}^{2} \\
\text { doxorubincin } 40 \mathrm{mg} / \mathrm{m}^{2} \\
\text { cyclophosphamide } 400 \mathrm{mg} / \mathrm{m}^{2} \\
\text { Complete resection }\end{array}$} \\
\hline Outcomes & \multicolumn{2}{|l|}{ Overall survival } \\
\hline Notes & \multicolumn{2}{|c|}{4 cycles of chemotherapy } \\
\hline \multicolumn{3}{|l|}{ Risk of bias } \\
\hline Bias & Authors' judgement & Support for judgement \\
\hline $\begin{array}{l}\text { Random sequence generation (selection } \\
\text { bias) }\end{array}$ & Low risk & $\begin{array}{l}\text { Data checks on IPD provided suggest adequate sequence gener- } \\
\text { ation }\end{array}$ \\
\hline Allocation concealment (selection bias) & Low risk & Central randomisation \\
\hline Selective reporting (reporting bias) & Low risk & N/A IPD supplied for outcomes \\
\hline $\begin{array}{l}\text { Blinding of participants and personnel } \\
\text { (performance bias) } \\
\text { All outcomes }\end{array}$ & Low risk & $\begin{array}{l}\text { Trial not blinded due to nature of intervention, outcome not } \\
\text { likely to be influenced by lack of blinding }\end{array}$ \\
\hline $\begin{array}{l}\text { Blinding of outcome assessment (detection } \\
\text { bias) } \\
\text { All outcomes }\end{array}$ & Low risk & $\begin{array}{l}\text { Trial not blinded due to nature of intervention, primary outcome } \\
\text { not likely to be influenced by lack of blinding }\end{array}$ \\
\hline
\end{tabular}

\section{A16 FLCSG 1}

\begin{tabular}{l|l}
\hline Methods & RCT: 1982 to 1987 \\
\hline Participants & $\begin{array}{l}110 \text { patients } \\
\text { Stage I-III }\end{array}$ \\
\hline Interventions & $\begin{array}{l}\text { surgery vs surgery }+ \text { chemotherapy } \\
6 \text { cycles of chemotherapy } \\
\text { cisplatin } 40 \mathrm{mg} / \mathrm{m}^{2} \\
\text { doxorubicin } 40 \mathrm{mg} / \mathrm{m}^{2} \\
\text { cyclophosphamide } 400 \mathrm{mg} / \mathrm{m}^{2}\end{array}$ \\
\hline \begin{tabular}{ll} 
Outcomes & Overall survival \\
\hline Adjuvant chemotherapy for resected early-stage non-small cell lung cancer (Review) \\
Copyright $\odot \mathbf{2 0 1 5}$ The Cochrane Collaboration. Published by John Wiley \& Sons, Ltd.
\end{tabular}
\end{tabular}


A16 FLCSG 1 (Continued)

Notes

Risk of bias

\begin{tabular}{l|l|l} 
Bias & Authors' judgement & Support for judgement \\
\hline $\begin{array}{l}\text { Random sequence generation (selection } \\
\text { bias) }\end{array}$ & Low risk & $\begin{array}{l}\text { Data checks on IPD provided suggest adequate sequence gener- } \\
\text { ation }\end{array}$ \\
\hline $\begin{array}{l}\text { Allocation concealment (selection bias) } \\
\text { Selective reporting (reporting bias) }\end{array}$ & Low risk & Lentral randomisation \\
\hline $\begin{array}{l}\text { Blinding of participants and personnel } \\
\text { (performance bias) } \\
\text { All outcomes }\end{array}$ & Low risk & IPD supplied for outcomes \\
\hline $\begin{array}{l}\text { Blinding of outcome assessment (detection } \\
\text { bias) } \\
\text { All outcomes }\end{array}$ & Low risk & $\begin{array}{l}\text { Trial not blinded due to nature of intervention, outcome not } \\
\text { likely to be influenced by lack of blinding }\end{array}$ \\
\hline
\end{tabular}

A17 LCSG 853

\begin{tabular}{ll}
\hline Methods & RCT: 1985 to 89 \\
\hline Participants & $\begin{array}{l}188 \text { patients } \\
\text { Stage II-III }\end{array}$ \\
\hline Interventions & $\begin{array}{l}\text { surgery vs surgery }+ \text { chemotherapy } \\
\text { cycles of chemotherapy } \\
\text { cisplatin } 60 \mathrm{mg} / \mathrm{m}^{2} \\
\text { doxorubicin } 40 \mathrm{mg} / \mathrm{m}^{2} \\
\text { cyclophosphamide } 400 \mathrm{mg} / \mathrm{m}^{2} \\
\text { Complete resection }\end{array}$ \\
\hline Outcomes & Overall survival \\
\hline Notes & \\
\hline
\end{tabular}

\section{Risk of bias}

\begin{tabular}{lll}
\hline Bias & Authors' judgement & Support for judgement \\
\hline $\begin{array}{l}\text { Random sequence generation (selection } \\
\text { bias) }\end{array}$ & Low risk & $\begin{array}{l}\text { Data checks on IPD provided suggest adequate sequence gener- } \\
\text { ation }\end{array}$ \\
\hline Allocation concealment (selection bias) & Low risk & Central randomisation
\end{tabular}




\section{A17 LCSG 853 (Continued)}

\begin{tabular}{l|l|l}
\hline Selective reporting (reporting bias) & Low risk & IPD supplied for outcomes \\
\hline $\begin{array}{l}\text { Blinding of participants and personnel } \\
\text { (performance bias) } \\
\text { All outcomes }\end{array}$ & Low risk & $\begin{array}{l}\text { Trial not blinded due to nature of intervention, outcome not } \\
\text { likely to be influenced by lack of blinding }\end{array}$ \\
\hline $\begin{array}{l}\text { Blinding of outcome assessment (detection } \\
\text { bias) }\end{array}$ & Low risk & $\begin{array}{l}\text { Trial not blinded due to nature of intervention, primary outcome } \\
\text { not likely to be influenced by lack of blinding }\end{array}$ \\
\hline
\end{tabular}

\section{A18 BLT3}

\begin{tabular}{|c|c|}
\hline Methods & RCT: 1995 to 2001 \\
\hline Participants & $\begin{array}{l}118 \text { patients } \\
\text { Stage I-III }\end{array}$ \\
\hline Interventions & $\begin{array}{l}\text { surgery vs surgery + chemotherapy } \\
3 \text { cycles of chemotherapy } \\
\text { cisplatin } 50 \mathrm{mg} / \mathrm{m}^{2} \\
\text { mitomycin } 6 \mathrm{mg} / \mathrm{m}^{2} \\
\text { ifosphamide } 3 \mathrm{mg} / \mathrm{m}^{2} \\
\text { Complete resection }\end{array}$ \\
\hline Outcomes & Overall survival \\
\hline Notes & 381 patients randomised in surgical setting, 118 patients relevant to this trial comparison \\
\hline
\end{tabular}

\section{Risk of bias}

Bias

Random sequence generation (selection Low risk bias)

\begin{tabular}{lll}
\hline Allocation concealment (selection bias) & Low risk & Central randomisation \\
\hline Selective reporting (reporting bias) & Low risk & IPD supplied for outcomes
\end{tabular}

Blinding of participants and personnel Low risk (performance bias)

All outcomes

Blinding of outcome assessment (detection Low risk bias)

All outcomes
Trial not blinded due to nature of intervention, outcome not likely to be influenced by lack of blinding

Trial not blinded due to nature of intervention, primary outcome not likely to be influenced by lack of blinding 
A19 SGACLC ACTLC1

\begin{tabular}{|c|c|c|}
\hline Methods & \multicolumn{2}{|l|}{ RCT: 1982 to 1985} \\
\hline Participants & \multicolumn{2}{|l|}{$\begin{array}{l}306 \text { patients } \\
\text { Stage NK }\end{array}$} \\
\hline Interventions & \multicolumn{2}{|c|}{$\begin{array}{l}\text { surgery vs surgery + chemotherapy } \\
10 \text { cycles of chemotherapy } \\
\text { cisplatin } 0.08 \mathrm{mg} / \mathrm{kg} \\
\text { mitomycin } 2 \mathrm{mg} / \mathrm{kg} \\
\text { tegafur } 12 \mathrm{mg} / \mathrm{kg} \text { daily treatment > } 6 \text { months }\end{array}$} \\
\hline Outcomes & \multicolumn{2}{|l|}{ Overall survival } \\
\hline \multicolumn{3}{|l|}{ Notes } \\
\hline \multicolumn{3}{|l|}{ Risk of bias } \\
\hline Bias & Authors' judgement & Support for judgement \\
\hline $\begin{array}{l}\text { Random sequence generation (selection } \\
\text { bias) }\end{array}$ & Low risk & $\begin{array}{l}\text { Data checks on IPD provided suggest adequate sequence gener- } \\
\text { ation }\end{array}$ \\
\hline Allocation concealment (selection bias) & Low risk & Central randomisation \\
\hline Selective reporting (reporting bias) & Low risk & IPD supplied for outcomes \\
\hline $\begin{array}{l}\text { Blinding of participants and personnel } \\
\text { (performance bias) } \\
\text { All outcomes }\end{array}$ & Low risk & $\begin{array}{l}\text { Trial not blinded due to nature of intervention, outcome not } \\
\text { likely to be influenced by lack of blinding }\end{array}$ \\
\hline $\begin{array}{l}\text { Blinding of outcome assessment (detection } \\
\text { bias) } \\
\text { All outcomes }\end{array}$ & Low risk & $\begin{array}{l}\text { Trial not blinded due to nature of intervention, primary outcome } \\
\text { not likely to be influenced by lack of blinding }\end{array}$ \\
\hline
\end{tabular}

\section{A20 OLCSG1c}

\begin{tabular}{ll}
\hline Methods & RCT: 1982 to 1987 \\
\hline Participants & $\begin{array}{l}28 \text { patients } \\
\text { Stage II }\end{array}$ \\
\hline Interventions & $\begin{array}{l}\text { surgery vs surgery }+ \text { chemotherapy } \\
1 \text { cycles of chemotherapy } \\
\text { cisplatin } 80 \mathrm{mg} / \mathrm{m}^{2} \\
\text { tegafur } 600-800 \mathrm{mg} / \mathrm{m}^{2}, \text { daily treatment }>1 \text { year } \\
\text { Complete resection }\end{array}$ \\
\hline Outcomes & Overall survival
\end{tabular}


A20 OLCSG1c (Continued)

Notes

Risk of bias

\begin{tabular}{l|l|l} 
Bias & Authors' judgement & Support for judgement \\
\hline $\begin{array}{l}\text { Random sequence generation (selection } \\
\text { bias) }\end{array}$ & Low risk & $\begin{array}{l}\text { Data checks on IPD provided suggest adequate sequence gener- } \\
\text { ation }\end{array}$ \\
\hline $\begin{array}{l}\text { Allocation concealment (selection bias) } \\
\text { Selective reporting (reporting bias) }\end{array}$ & Low risk & Lentral randomisation \\
\hline $\begin{array}{l}\text { Blinding of participants and personnel } \\
\text { (performance bias) } \\
\text { All outcomes }\end{array}$ & Low risk & IPD supplied for outcomes \\
\hline $\begin{array}{l}\text { Blinding of outcome assessment (detection } \\
\text { bias) } \\
\text { All outcomes }\end{array}$ & Low risk & $\begin{array}{l}\text { Trial not blinded due to nature of intervention, outcome not } \\
\text { likely to be influenced by lack of blinding }\end{array}$ \\
\hline
\end{tabular}

A21 SGACLC ACTLC2

\begin{tabular}{l|l}
\hline Methods & RCT: 1985 to 1987 \\
\hline Participants & $\begin{array}{l}332 \text { patients } \\
\text { Stage I-III }\end{array}$ \\
\hline Interventions & $\begin{array}{l}\text { surgery vs surgery }+ \text { chemotherapy } \\
\text { cisplatin } 66 \mathrm{mg} / \mathrm{m}^{2} \\
\text { doxorubicin } 26 \mathrm{mg} / \mathrm{m}^{2} \\
\text { UFT } 8 \mathrm{mg} / \mathrm{kg}, \text { daily treatment }>6 \text { months } \\
\text { Complete and incomplete resection }\end{array}$ \\
\hline Outcomes & Overall survival \\
\hline Notes & Unpublished \\
\hline
\end{tabular}

Risk of bias

Bias

Random sequence generation (selection Low risk bias)

Allocation concealment (selection bias)

Selective reporting (reporting bias)

\section{Authors' judgement Support for judgement}

Data checks on IPD provided suggest adequate sequence generation

Sealed envelope

IPD supplied for outcomes 


\section{A21 SGACLC ACTLC2 (Continued)}

Blinding of participants and personnel Low risk (performance bias)

All outcomes

Blinding of outcome assessment (detection Low risk bias)

All outcomes
Trial not blinded due to nature of intervention, outcome not likely to be influenced by lack of blinding

Trial not blinded due to nature of intervention, primary outcome not likely to be influenced by lack of blinding

A22 WJSG $2(1+3)$

\begin{tabular}{|c|c|c|}
\hline Methods & \multicolumn{2}{|l|}{ RCT: 1985 to 1988} \\
\hline Participants & \multicolumn{2}{|l|}{$\begin{array}{l}323 \text { patients } \\
\text { Stage I-III }\end{array}$} \\
\hline Interventions & \multicolumn{2}{|c|}{$\begin{array}{l}\text { surgery vs surgery }+ \text { chemotherapy } \\
1 \text { cycle of chemotherapy } \\
\text { cisplatin } 50 \mathrm{mg} / \mathrm{m}^{2} \\
\text { vindesine } 6-9 \mathrm{mg} / \mathrm{m}^{2} \\
\text { UFT } 400 \mathrm{mg} / \mathrm{m}^{2} \text {, daily treatment } 1 \text { year } \\
\text { Complete resection }\end{array}$} \\
\hline Outcomes & \multicolumn{2}{|l|}{ Overall survival } \\
\hline \multicolumn{3}{|l|}{ Notes } \\
\hline \multicolumn{3}{|l|}{ Risk of bias } \\
\hline Bias & Authors' judgement & Support for judgement \\
\hline $\begin{array}{l}\text { Random sequence generation (selection } \\
\text { bias) }\end{array}$ & Low risk & $\begin{array}{l}\text { Data checks on IPD provided suggest adequate sequence gener- } \\
\text { ation }\end{array}$ \\
\hline Allocation concealment (selection bias) & Low risk & Central randomisation \\
\hline Selective reporting (reporting bias) & Low risk & IPD supplied for outcomes \\
\hline $\begin{array}{l}\text { Blinding of participants and personnel } \\
\text { (performance bias) } \\
\text { All outcomes }\end{array}$ & Low risk & $\begin{array}{l}\text { Trial not blinded due to nature of intervention, outcome not } \\
\text { likely to be influenced by lack of blinding }\end{array}$ \\
\hline $\begin{array}{l}\text { Blinding of outcome assessment (detection } \\
\text { bias) } \\
\text { All outcomes }\end{array}$ & Low risk & $\begin{array}{l}\text { Trial not blinded due to nature of intervention, primary outcome } \\
\text { not likely to be influenced by lack of blinding }\end{array}$ \\
\hline
\end{tabular}


A23 WJSG3

\begin{tabular}{l|l}
\hline Methods & RCT: 1988 to 1989 \\
\hline Participants & $\begin{array}{l}225 \text { patients } \\
\text { Stage I-II }\end{array}$ \\
\hline Interventions & $\begin{array}{l}\text { surgery vs surgery }+ \text { chemotherapy } \\
2 \text { cycles of chemotherapy } \\
\text { cisplatin } 80 \mathrm{mg} / \mathrm{m}^{2} \\
\text { vindesine } 2-3 \mathrm{mg} / \mathrm{m}^{2} \\
\text { mitomycin } 8 \mathrm{mg} / \mathrm{m}^{2} \\
\text { tegafur and uracil } 400 \mathrm{mg} / \mathrm{m}^{2} \text { (total), daily treatment for } 1 \text { year } \\
\text { Complete resection }\end{array}$ \\
\hline Outcomes & Overall survival \\
\hline Notes & \\
\hline
\end{tabular}

Risk of bias

Bias

Authors' judgement Support for judgement

Random sequence generation (selection Low risk bias)

Data checks on IPD provided suggest adequate sequence generation

\begin{tabular}{lll}
\hline Allocation concealment (selection bias) & Low risk & Central randomisation \\
\hline Selective reporting (reporting bias) & Low risk & IPD supplied for outcomes \\
\hline
\end{tabular}

Blinding of participants and personnel Low risk (performance bias)

Trial not blinded due to nature of intervention, outcome not likely to be influenced by lack of blinding

All outcomes

Blinding of outcome assessment (detection Low risk bias)

Trial not blinded due to nature of intervention, primary outcome not likely to be influenced by lack of blinding

All outcomes

\section{A24 Xu}

\begin{tabular}{ll} 
Methods & RCT: 1989 to 1992 \\
\hline Participants & $\begin{array}{l}70 \text { patients } \\
\text { Stage I-III }\end{array}$ \\
\hline Interventions & $\begin{array}{l}\text { surgery vs surgery + chemotherapy } \\
4 \text { cycles of chemotherapy } \\
\text { cisplatin } 100 \mathrm{mg} / \mathrm{m}^{2} \\
\text { cyclophosphamide } 300 \mathrm{mg} / \mathrm{m}^{2} \\
\text { vincristine } 1.4 \mathrm{mg} / \mathrm{m}^{2} \\
\text { doxorubicin } 50 \mathrm{mg} / \mathrm{m}^{2}\end{array}$ \\
\hline
\end{tabular}


A24 Xu (Continued)

lomustine $50 \mathrm{mg} / \mathrm{m}^{2}$

oral tegaful $600-900 \mathrm{mg} / \mathrm{m}^{2}$ (total), daily treatment for 1 year

Complete resection

Outcomes Overall survival

Notes

\section{Risk of bias}

\begin{tabular}{l|l|l}
\hline Bias & Authors' judgement & Support for judgement \\
\hline $\begin{array}{l}\text { Random sequence generation (selection } \\
\text { bias) }\end{array}$ & Low risk & $\begin{array}{l}\text { Data checks on IPD provided suggest adequate sequence gener- } \\
\text { ation }\end{array}$ \\
\hline $\begin{array}{l}\text { Allocation concealment (selection bias) } \\
\text { Selective reporting (reporting bias) }\end{array}$ & Low risk & Sealed envelope \\
\hline $\begin{array}{l}\text { Blinding of participants and personnel } \\
\text { (performance bias) } \\
\text { All outcomes }\end{array}$ & Low risk & IPD supplied for outcomes \\
\hline $\begin{array}{l}\text { Blinding of outcome assessment (detection } \\
\text { bias) } \\
\text { All outcomes }\end{array}$ & Low risk & $\begin{array}{l}\text { Trial not blinded due to nature of intervention, outcome not } \\
\text { likely to be influenced by lack of blinding }\end{array}$ \\
\hline
\end{tabular}

A25 ACTLC4a

\begin{tabular}{l|l}
\hline Methods & RCT: 1982 to 1988 \\
\hline Participants & $\begin{array}{l}104 \text { patients } \\
\text { Stage I }\end{array}$ \\
\hline Interventions & $\begin{array}{l}\text { surgery vs surgery }+ \text { chemotherapy } \\
\text { cisplatin } 80 \mathrm{mg} / \mathrm{m}^{2}, 1 \mathrm{cycle} \\
\text { vindesine } 6 \mathrm{mg} / \mathrm{m}^{2}, 2 \mathrm{cycles} \\
\text { tegafur and uracil } 400 \mathrm{mg} / \mathrm{m}^{2} \text { (total), daily treatment for } 2 \text { years } \\
\text { Complete resection }\end{array}$ \\
\hline Outcomes & $\begin{array}{l}\text { Overall survival } \\
\text { Recurrence-free survival } \\
\text { Toxicity }\end{array}$ \\
\hline Notes & \begin{tabular}{l}
156 patients randomised in trial, 104 patients relevant to this trial comparison \\
\hline
\end{tabular}
\end{tabular}

Risk of bias 


\section{A25 ACTLC4a (Continued)}

\begin{tabular}{|c|c|c|}
\hline Bias & Authors' judgement & Support for judgement \\
\hline $\begin{array}{l}\text { Random sequence generation (selection } \\
\text { bias) }\end{array}$ & Low risk & $\begin{array}{l}\text { Data checks on IPD provided suggest adequate sequence gener- } \\
\text { ation }\end{array}$ \\
\hline Allocation concealment (selection bias) & Low risk & Central randomisation \\
\hline Selective reporting (reporting bias) & Low risk & IPD supplied for outcomes \\
\hline $\begin{array}{l}\text { Blinding of participants and personnel } \\
\text { (performance bias) } \\
\text { All outcomes }\end{array}$ & Low risk & $\begin{array}{l}\text { Trial not blinded due to nature of intervention, outcome not } \\
\text { likely to be influenced by lack of blinding }\end{array}$ \\
\hline $\begin{array}{l}\text { Blinding of outcome assessment (detection } \\
\text { bias) } \\
\text { All outcomes }\end{array}$ & Low risk & $\begin{array}{l}\text { Trial not blinded due to nature of intervention, primary outcome } \\
\text { not likely to be influenced by lack of blinding }\end{array}$ \\
\hline
\end{tabular}

\section{A26 OLCSG2b}

\begin{tabular}{ll} 
Methods & RCT: 1992 to 1994 \\
\hline Participants & $\begin{array}{l}95 \text { patients } \\
\text { Stage II-III }\end{array}$ \\
\hline Interventions & $\begin{array}{l}\text { surgery vs surgery }+ \text { chemotherapy } \\
2 \text { cycles of chemotherapy } \\
\text { cisplatin } 80 \mathrm{mg} / \mathrm{m}^{2} \\
\text { vindesine } 6 \mathrm{mg} / \mathrm{m}^{2} \\
\text { tegafur and uracil } 400 \mathrm{mg} / \mathrm{m}^{2} \text { (total), daily treatment for } 1 \text { year } \\
\text { Complete resection }\end{array}$ \\
\hline Outcomes & Overall survival \\
\hline Notes & 267 patients randomised in trial, 95 patients relevant to this trial comparison
\end{tabular}

\section{Risk of bias}

\begin{tabular}{l|l|l} 
Bias & Authors' judgement & Support for judgement \\
\hline $\begin{array}{l}\text { Random sequence generation (selection } \\
\text { bias) }\end{array}$ & Low risk & $\begin{array}{l}\text { Data checks on IPD provided suggest adequate sequence gener- } \\
\text { ation }\end{array}$ \\
\hline Allocation concealment (selection bias) & Low risk & Central randomisation \\
\hline Selective reporting (reporting bias) & Low risk & IPD supplied for outcomes
\end{tabular}




\section{A26 OLCSG2b (Continued)}

Blinding of participants and personnel Low risk (performance bias)

All outcomes

Blinding of outcome assessment (detection Low risk bias)

All outcomes
Trial not blinded due to nature of intervention, outcome not likely to be influenced by lack of blinding

Trial not blinded due to nature of intervention, primary outcome not likely to be influenced by lack of blinding

\section{A27 OLCSG1b}

\begin{tabular}{|c|c|c|}
\hline Methods & \multicolumn{2}{|l|}{ RCT: 1982 to 1986} \\
\hline Participants & \multicolumn{2}{|l|}{$\begin{array}{l}83 \text { patients } \\
\text { Stage II-III }\end{array}$} \\
\hline Interventions & \multicolumn{2}{|c|}{$\begin{array}{l}\text { surgery vs surgery }+ \text { chemotherapy } \\
3 \text { cycles of chemotherapy } \\
\text { doxorubicin } 100 \mathrm{mg} / \mathrm{m}^{2} \\
\text { mitomycin } 20 \mathrm{mg} / \mathrm{m}^{2} \\
\text { tegafur } 600-800 \mathrm{mg} / \mathrm{m}^{2} \text {, daily treatment } \\
\text { followed by tegafur } 600-800 \mathrm{mg} / \mathrm{m}^{2} \text { daily treatment }>1 \text { year } \\
\text { Complete and incomplete resection }\end{array}$} \\
\hline Outcomes & \multicolumn{2}{|c|}{$\begin{array}{l}\text { Overall survival } \\
\text { Recurrence-free interval }\end{array}$} \\
\hline Notes & \multicolumn{2}{|c|}{363 patients randomised in trial, 83 patients relevant to this trial comparison } \\
\hline \multicolumn{3}{|l|}{ Risk of bias } \\
\hline Bias & Authors' judgement & Support for judgement \\
\hline $\begin{array}{l}\text { Random sequence generation (selection } \\
\text { bias) }\end{array}$ & Low risk & $\begin{array}{l}\text { Data checks on IPD provided suggest adequate sequence gener- } \\
\text { ation }\end{array}$ \\
\hline Allocation concealment (selection bias) & Low risk & Central randomisation \\
\hline Selective reporting (reporting bias) & Low risk & IPD supplied for outcomes \\
\hline $\begin{array}{l}\text { Blinding of participants and personnel } \\
\text { (performance bias) } \\
\text { All outcomes }\end{array}$ & Low risk & $\begin{array}{l}\text { Trial not blinded due to nature of intervention, outcome not } \\
\text { likely to be influenced by lack of blinding }\end{array}$ \\
\hline $\begin{array}{l}\text { Blinding of outcome assessment (detection } \\
\text { bias) } \\
\text { All outcomes }\end{array}$ & Low risk & $\begin{array}{l}\text { Trial not blinded due to nature of intervention, primary outcome } \\
\text { not likely to be influenced by lack of blinding }\end{array}$ \\
\hline
\end{tabular}




\section{A28 OLCSG1a}

Methods

\begin{tabular}{|c|c|c|}
\hline Participants & \multicolumn{2}{|l|}{$\begin{array}{l}321 \text { patients } \\
\text { Stage I }\end{array}$} \\
\hline Interventions & \multicolumn{2}{|c|}{$\begin{array}{l}\text { surgery vs surgery }+ \text { chemotherapy } \\
\text { tegafur } 600-800 \mathrm{mg} / \mathrm{m}^{2} \text {, daily treatment }>1 \text { year } \\
\text { Complete resection }\end{array}$} \\
\hline Outcomes & \multicolumn{2}{|c|}{$\begin{array}{l}\text { Overall survival } \\
\text { Recurrence-free interval }\end{array}$} \\
\hline Notes & \multicolumn{2}{|c|}{363 patients randomised in trial, 321 patients relevant to this trial comparison } \\
\hline \multicolumn{3}{|l|}{ Risk of bias } \\
\hline Bias & Authors' judgement & Support for judgement \\
\hline $\begin{array}{l}\text { Random sequence generation (selection } \\
\text { bias) }\end{array}$ & Low risk & $\begin{array}{l}\text { Data checks on IPD provided suggest adequate sequence gener- } \\
\text { ation }\end{array}$ \\
\hline Allocation concealment (selection bias) & Low risk & Central randomisation \\
\hline Selective reporting (reporting bias) & Low risk & IPD supplied for outcomes \\
\hline $\begin{array}{l}\text { Blinding of participants and personnel } \\
\text { (performance bias) } \\
\text { All outcomes }\end{array}$ & Low risk & $\begin{array}{l}\text { Trial not blinded due to nature of intervention, outcome not } \\
\text { likely to be influenced by lack of blinding }\end{array}$ \\
\hline $\begin{array}{l}\text { Blinding of outcome assessment (detection } \\
\text { bias) } \\
\text { All outcomes }\end{array}$ & Low risk & $\begin{array}{l}\text { Trial not blinded due to nature of intervention, primary outcome } \\
\text { not likely to be influenced by lack of blinding }\end{array}$ \\
\hline
\end{tabular}

A29 WJSG2 (2+3)

\begin{tabular}{l|l}
\hline Methods & RCT: 1985 to 1988 \\
\hline Participants & $\begin{array}{l}208 \text { patients } \\
\text { Stage I-III }\end{array}$ \\
\hline Interventions & $\begin{array}{l}\text { surgery vs surgery }+ \text { chemotherapy } \\
\text { tegafur and uracil } 400 \mathrm{mg} / \mathrm{m}^{2}, \text { daily treatment for } 1 \text { year } \\
\text { Complete resection }\end{array}$ \\
\hline Outcomes & Overall survival \\
\hline Notes & 323 patients randomised in trial, 208 patients relevant to this comparison
\end{tabular}


A29 WJSG2 (2+3) (Continued)

\section{Risk of bias}

\begin{tabular}{|c|c|c|}
\hline Bias & Authors' judgement & Support for judgement \\
\hline $\begin{array}{l}\text { Random sequence generation (selection } \\
\text { bias) }\end{array}$ & Low risk & $\begin{array}{l}\text { Data checks on IPD provided suggest adequate sequence gener- } \\
\text { ation }\end{array}$ \\
\hline Allocation concealment (selection bias) & Low risk & Central randomisation \\
\hline Selective reporting (reporting bias) & Low risk & IPD supplied for outcomes \\
\hline $\begin{array}{l}\text { Blinding of participants and personnel } \\
\text { (performance bias) } \\
\text { All outcomes }\end{array}$ & Low risk & $\begin{array}{l}\text { Trial not blinded due to nature of intervention, outcome not } \\
\text { likely to be influenced by lack of blinding }\end{array}$ \\
\hline $\begin{array}{l}\text { Blinding of outcome assessment (detection } \\
\text { bias) } \\
\text { All outcomes }\end{array}$ & Low risk & $\begin{array}{l}\text { Trial not blinded due to nature of intervention, primary outcome } \\
\text { not likely to be influenced by lack of blinding }\end{array}$ \\
\hline
\end{tabular}

\section{A30 WJSG4}

\begin{tabular}{ll}
\hline Methods & RCT: 1991 to 1994 \\
\hline Participants & $\begin{array}{l}367 \text { patients } \\
\text { Stage I-II }\end{array}$ \\
\hline Interventions & $\begin{array}{l}\text { surgery vs surgery }+ \text { chemotherapy } \\
\text { tegafur and uracil } 400 \mathrm{mg} / \mathrm{m}^{2} \text { (total), daily treatment for } 1 \text { year } \\
\text { Complete resection }\end{array}$ \\
\hline Outcomes & Overall survival \\
\hline Notes & \\
\hline
\end{tabular}

\section{Risk of bias}

\section{Bias}

Random sequence generation (selection Low risk bias)

\begin{tabular}{l|ll}
\hline Allocation concealment (selection bias) & Low risk & Central randomisation \\
\hline Selective reporting (reporting bias) & Low risk & IPD supplied for outcomes \\
\hline $\begin{array}{l}\text { Blinding of participants and personnel } \\
\text { (performance bias) } \\
\text { All outcomes }\end{array}$ & Low risk & $\begin{array}{l}\text { Trial not blinded due to nature of intervention, outcome not } \\
\text { likely to be influenced by lack of blinding }\end{array}$ \\
\hline
\end{tabular}

Adjuvant chemotherapy for resected early-stage non-small cell lung cancer (Review)

Copyright @ 2015 The Cochrane Collaboration. Published by John Wiley \& Sons, Ltd.

\section{Authors' judgement Support for judgement}

Data checks on IPD provided suggest adequate sequence generation 


\section{A30 WJSG4 (Continued)}

Blinding of outcome assessment (detection Low risk bias)

All outcomes
Trial not blinded due to nature of intervention, primary outcome not likely to be influenced by lack of blinding

\section{A31 NJSGLCS}

\begin{tabular}{|c|c|c|}
\hline Methods & \multicolumn{2}{|l|}{ RCT: 1992 to 1994} \\
\hline Participants & \multicolumn{2}{|l|}{$\begin{array}{l}219 \text { patients } \\
\text { Stage I-II }\end{array}$} \\
\hline Interventions & \multicolumn{2}{|c|}{$\begin{array}{l}\text { surgery vs surgery }+ \text { chemotherapy } \\
\text { tegafur and uracil } 260 \mathrm{mg} / \mathrm{m}^{2} \text { total or } 400 \mathrm{mg} / \mathrm{m}^{2} \text { total, daily treatment for } 2 \text { years } \\
\text { Complete resection }\end{array}$} \\
\hline Outcomes & \multicolumn{2}{|c|}{$\begin{array}{l}\text { Overall survival } \\
\text { Recurrence-free survival } \\
\text { Toxicity }\end{array}$} \\
\hline \multicolumn{3}{|l|}{ Notes } \\
\hline \multicolumn{3}{|l|}{ Risk of bias } \\
\hline Bias & Authors' judgement & Support for judgement \\
\hline $\begin{array}{l}\text { Random sequence generation (selection } \\
\text { bias) }\end{array}$ & Low risk & $\begin{array}{l}\text { Data checks on IPD provided suggest adequate sequence gener- } \\
\text { ation }\end{array}$ \\
\hline Allocation concealment (selection bias) & Low risk & Central randomisation \\
\hline Selective reporting (reporting bias) & Low risk & IPD supplied for outcomes \\
\hline $\begin{array}{l}\text { Blinding of participants and personnel } \\
\text { (performance bias) } \\
\text { All outcomes }\end{array}$ & Low risk & $\begin{array}{l}\text { Trial not blinded due to nature of intervention, outcome not } \\
\text { likely to be influenced by lack of blinding }\end{array}$ \\
\hline $\begin{array}{l}\text { Blinding of outcome assessment (detection } \\
\text { bias) } \\
\text { All outcomes }\end{array}$ & Low risk & $\begin{array}{l}\text { Trial not blinded due to nature of intervention, primary outcome } \\
\text { not likely to be influenced by lack of blinding }\end{array}$ \\
\hline
\end{tabular}

\section{A32 OLCSG2a}

\begin{tabular}{ll} 
Methods & RCT: 1992 to 1994 \\
\hline Participants & $\begin{array}{l}172 \text { patients } \\
\text { Stage I }\end{array}$
\end{tabular}




\section{A32 OLCSG2a (Continued)}

\begin{tabular}{|c|c|c|}
\hline Interventions & \multicolumn{2}{|c|}{$\begin{array}{l}\text { surgery vs surgery }+ \text { chemotherapy } \\
\text { tegafur and uracil } 400 \mathrm{mg} / \mathrm{m}^{2} \text { (total), daily treatment for } 1 \text { year } \\
\text { Complete resection }\end{array}$} \\
\hline Outcomes & \multicolumn{2}{|c|}{$\begin{array}{l}\text { Overall survival } \\
\text { Recurrence-free survival }\end{array}$} \\
\hline Notes & \multicolumn{2}{|c|}{267 patients randomised in trial, 172 relevant to this comparison } \\
\hline \multicolumn{3}{|l|}{ Risk of bias } \\
\hline Bias & Authors' judgement & Support for judgement \\
\hline $\begin{array}{l}\text { Random sequence generation (selection } \\
\text { bias) }\end{array}$ & Low risk & $\begin{array}{l}\text { Data checks on IPD provided suggest adequate sequence gener- } \\
\text { ation }\end{array}$ \\
\hline Allocation concealment (selection bias) & Low risk & Central randomisation \\
\hline Selective reporting (reporting bias) & Low risk & IPD supplied for outcomes \\
\hline $\begin{array}{l}\text { Blinding of participants and personnel } \\
\text { (performance bias) } \\
\text { All outcomes }\end{array}$ & Low risk & $\begin{array}{l}\text { Trial not blinded due to nature of intervention, outcome not } \\
\text { likely to be influenced by lack of blinding }\end{array}$ \\
\hline $\begin{array}{l}\text { Blinding of outcome assessment (detection } \\
\text { bias) } \\
\text { All outcomes }\end{array}$ & Low risk & $\begin{array}{l}\text { Trial not blinded due to nature of intervention, primary outcome } \\
\text { not likely to be influenced by lack of blinding }\end{array}$ \\
\hline
\end{tabular}

\section{A33 ACTLC4b}

$\begin{array}{ll}\text { Methods } & \text { RCT: } 1992 \text { to } 1995\end{array}$

Participants 104 patients

Stage I

Interventions

surgery vs surgery + chemotherapy

tegafur and uracil $400 \mathrm{mg} / \mathrm{m}^{2}$ (total), daily treatment for 2 years

Complete resection

$\begin{array}{ll}\text { Outcomes } & \text { Overall survival } \\ & \text { Recurrence-free survival } \\ & \text { Safety }\end{array}$

Notes

156 patients randomised in trial, 104 relevant to this comparison

\section{Risk of bias}




\section{A33 ACTLC4b (Continued)}

\begin{tabular}{|c|c|c|}
\hline Bias & Authors' judgement & Support for judgement \\
\hline $\begin{array}{l}\text { Random sequence generation (selection } \\
\text { bias) }\end{array}$ & Low risk & $\begin{array}{l}\text { Data checks on IPD provided suggest adequate sequence gener- } \\
\text { ation }\end{array}$ \\
\hline Allocation concealment (selection bias) & Low risk & Central randomisation \\
\hline Selective reporting (reporting bias) & Low risk & IPD supplied for outcomes \\
\hline $\begin{array}{l}\text { Blinding of participants and personnel } \\
\text { (performance bias) } \\
\text { All outcomes }\end{array}$ & Low risk & $\begin{array}{l}\text { Trial not blinded due to nature of intervention, outcome not } \\
\text { likely to be influenced by lack of blinding }\end{array}$ \\
\hline $\begin{array}{l}\text { Blinding of outcome assessment (detection } \\
\text { bias) } \\
\text { All outcomes }\end{array}$ & Low risk & $\begin{array}{l}\text { Trial not blinded due to nature of intervention, primary outcome } \\
\text { not likely to be influenced by lack of blinding }\end{array}$ \\
\hline
\end{tabular}

\section{A34 JLCRG}

\begin{tabular}{ll}
\hline Methods & RCT: 1994 to 1997 \\
\hline Participants & $\begin{array}{l}999 \text { patients } \\
\text { Stage I }\end{array}$ \\
\hline Interventions & $\begin{array}{l}\text { surgery vs surgery }+ \text { chemotherapy } \\
\text { tegafur and uracil } 250 \mathrm{mg} / \mathrm{m}^{2}(\text { total }), \text { daily treatment for } 2 \text { years } \\
\text { Complete and incomplete resection }\end{array}$ \\
\hline Outcomes & Overall survival \\
\hline Notes & \\
\hline
\end{tabular}

\section{Risk of bias}

\section{Bias}

\section{Authors' judgement Support for judgement}

Random sequence generation (selection Low risk bias)

Data checks on IPD provided suggest adequate sequence generation

\begin{tabular}{lll} 
Allocation concealment (selection bias) & Low risk & Central randomisation \\
\hline Selective reporting (reporting bias) & Low risk & IPD supplied for outcomes \\
\hline
\end{tabular}

Blinding of participants and personnel Low risk (performance bias)

All outcomes
Trial not blinded due to nature of intervention, outcome not likely to be influenced by lack of blinding 


\section{A34 JLCRG (Continued)}

Blinding of outcome assessment (detection Low risk bias)

All outcomes
Trial not blinded due to nature of intervention, primary outcome not likely to be influenced by lack of blinding

B01 MSKCC 80-53

\begin{tabular}{|c|c|c|}
\hline Methods & \multicolumn{2}{|l|}{ RCT: 1981 to 1987} \\
\hline Participants & \multicolumn{2}{|l|}{$\begin{array}{l}72 \text { patients } \\
\text { Stage III }\end{array}$} \\
\hline Interventions & \multicolumn{2}{|c|}{$\begin{array}{l}\text { surgery + radiotherapy vs surgery + radiotherapy + chemotherapy } \\
\text { cisplatin } 120 \mathrm{mg} / \mathrm{m}^{2} \\
\text { vindesine } 9 \mathrm{mg} / \mathrm{m}^{2} \\
4 \text { cycles of chemotherapy } \\
\text { radiotherapy } 46 \mathrm{~Gy} \\
\text { complete and incomplete resections }\end{array}$} \\
\hline Outcomes & \multicolumn{2}{|l|}{ Overall survival } \\
\hline \multicolumn{3}{|l|}{ Notes } \\
\hline \multicolumn{3}{|l|}{ Risk of bias } \\
\hline Bias & Authors' judgement & Support for judgement \\
\hline $\begin{array}{l}\text { Random sequence generation (selection } \\
\text { bias) }\end{array}$ & Low risk & $\begin{array}{l}\text { Data checks on IPD provided suggest adequate sequence gener- } \\
\text { ation }\end{array}$ \\
\hline Allocation concealment (selection bias) & Unclear risk & Not reported (unpublished) \\
\hline Selective reporting (reporting bias) & Low risk & IPD supplied for outcomes \\
\hline $\begin{array}{l}\text { Blinding of participants and personnel } \\
\text { (performance bias) } \\
\text { All outcomes }\end{array}$ & Low risk & $\begin{array}{l}\text { Trial not blinded due to nature of intervention, outcome not } \\
\text { likely to be influenced by lack of blinding }\end{array}$ \\
\hline $\begin{array}{l}\text { Blinding of outcome assessment (detection } \\
\text { bias) } \\
\text { All outcomes }\end{array}$ & Low risk & $\begin{array}{l}\text { Trial not blinded due to nature of intervention, outcome not } \\
\text { likely to be influenced by lack of blinding }\end{array}$ \\
\hline
\end{tabular}




\begin{tabular}{|c|c|c|}
\hline Methods & \multicolumn{2}{|l|}{ RCT: 1982 to 1986} \\
\hline Participants & \multicolumn{2}{|l|}{$\begin{array}{l}267 \text { patients } \\
\text { Stage I-III }\end{array}$} \\
\hline Interventions & \multicolumn{2}{|c|}{$\begin{array}{l}\text { surgery + radiotherapy vs surgery + radiotherapy + chemotherapy } \\
\text { doxorubicin } 40 \mathrm{mg} / \mathrm{m}^{2} \\
\text { vincristine } 1.2 \mathrm{mg} / \mathrm{m}^{2} \\
\text { cisplatin } 75 \mathrm{mg} / \mathrm{m}^{2} \\
\text { lomustine } 80 \mathrm{mg} / \mathrm{m}^{2} \text { (total) alternating with cyclophosphamide } 600 \mathrm{mg} / \mathrm{m}^{2} \\
3 \text { cycles of chemotherapy given before radiotherapy } \\
\text { radiotherapy } 60-65 \text { Gy in } 30-33 \text { fractions } \\
\text { complete and incomplete resection }\end{array}$} \\
\hline Outcomes & \multicolumn{2}{|c|}{$\begin{array}{l}\text { Overall survival } \\
\text { Recurrence-free survival }\end{array}$} \\
\hline \multicolumn{3}{|l|}{ Notes } \\
\hline \multicolumn{3}{|l|}{ Risk of bias } \\
\hline Bias & Authors' judgement & Support for judgement \\
\hline $\begin{array}{l}\text { Random sequence generation (selection } \\
\text { bias) }\end{array}$ & Low risk & $\begin{array}{l}\text { Data checks on IPD provided suggest adequate sequence gener- } \\
\text { ation }\end{array}$ \\
\hline Allocation concealment (selection bias) & Low risk & Central randomisation \\
\hline Selective reporting (reporting bias) & Low risk & IPD supplied for all outcomes \\
\hline $\begin{array}{l}\text { Blinding of participants and personnel } \\
\text { (performance bias) } \\
\text { All outcomes }\end{array}$ & Low risk & $\begin{array}{l}\text { Trial not blinded due to nature of intervention, outcome not } \\
\text { likely to be influenced by lack of blinding }\end{array}$ \\
\hline $\begin{array}{l}\text { Blinding of outcome assessment (detection } \\
\text { bias) } \\
\text { All outcomes }\end{array}$ & Low risk & $\begin{array}{l}\text { Trial not blinded due to nature of intervention, outcome not } \\
\text { likely to be influenced by lack of blinding }\end{array}$ \\
\hline \multicolumn{3}{|l|}{ B03 EORTC 08861} \\
\hline Methods & \multicolumn{2}{|l|}{ RCT: 1986 to 1990} \\
\hline
\end{tabular}

B03 EORTC 08861

Methods
RCT: 1986 to 1990

22 patients

Stage IIB-IIIA

Interventions

surgery + radiotherapy vs surgery + radiotherapy + chemotherapy

cisplatin $100 \mathrm{mg} / \mathrm{m}^{2}$

vindesine $6 \mathrm{mg} / \mathrm{m}^{2}$

4 cycles of chemotherapy, 2 given before radiotherapy 
B03 EORTC 08861 (Continued)

radiotherapy 56 Gy in 28 fractions

complete resection

\begin{tabular}{ll}
\hline Outcomes & Overall survival \\
\hline Notes & unpublished \\
\hline
\end{tabular}

\section{Risk of bias}

Bias

Authors' judgement Support for judgement

Random sequence generation (selection Low risk bias)

Data checks on IPD provided suggest adequate sequence generation

\begin{tabular}{lll} 
Allocation concealment (selection bias) & Low risk & Central randomisation \\
\hline Selective reporting (reporting bias) & Low risk & IPD supplied for all outcomes \\
\hline
\end{tabular}

Blinding of participants and personnel Low risk (performance bias)

Trial not blinded due to nature of intervention, outcome not likely to be influenced by lack of blinding

All outcomes

Blinding of outcome assessment (detection Low risk bias)

Trial not blinded due to nature of intervention, outcome not likely to be influenced by lack of blinding

All outcomes

B04 MDA DM 87045

\begin{tabular}{ll}
\hline Methods & RCT: 1987 to 1993 \\
\hline Participants & $\begin{array}{l}34 \text { patients } \\
\text { Stage NK }\end{array}$ \\
\hline Interventions & $\begin{array}{l}\text { surgery }+ \text { radiotherapy vs surgery + radiotherapy + chemotherapy } \\
\text { cisplatin } 50-100 \mathrm{mg} / \mathrm{m}^{2} \\
\text { etoposide } 60-120 \mathrm{mg} / \mathrm{m}^{2} \\
\text { cyclophosphamide } 300-600 \mathrm{mg} / \mathrm{m}^{2} \\
\text { CT given before } \mathrm{RT}, \mathrm{number} \text { of cycles unknown } \\
\text { radiotherapy } 50-60 \mathrm{~Gy} \text { in } 25-33 \text { fractions } \\
\text { incomplete resection }\end{array}$ \\
\hline Outcomes & $\begin{array}{l}\text { Overall survival } \\
\text { Recurrence-free survival }\end{array}$ \\
\hline Notes & \begin{tabular}{l} 
Unpublished \\
\hline
\end{tabular}
\end{tabular}

\section{Risk of bias}


B04 MDA DM 87045 (Continued)

\begin{tabular}{|c|c|c|}
\hline Bias & Authors' judgement & Support for judgement \\
\hline $\begin{array}{l}\text { Random sequence generation (selection } \\
\text { bias) }\end{array}$ & Low risk & $\begin{array}{l}\text { Data checks on IPD provided suggest adequate sequence gener- } \\
\text { ation }\end{array}$ \\
\hline Allocation concealment (selection bias) & Low risk & Central randomisation \\
\hline Selective reporting (reporting bias) & Low risk & IPD supplied for outcomes \\
\hline $\begin{array}{l}\text { Blinding of participants and personnel } \\
\text { (performance bias) } \\
\text { All outcomes }\end{array}$ & Low risk & $\begin{array}{l}\text { Trial not blinded due to nature of intervention, outcome not } \\
\text { likely to be influenced by lack of blinding }\end{array}$ \\
\hline $\begin{array}{l}\text { Blinding of outcome assessment (detection } \\
\text { bias) } \\
\text { All outcomes }\end{array}$ & Low risk & $\begin{array}{l}\text { Trial not blinded due to nature of intervention, outcome not } \\
\text { likely to be influenced by lack of blinding }\end{array}$ \\
\hline
\end{tabular}

\section{B05 INT 0115}

\begin{tabular}{|c|c|c|}
\hline Methods & \multicolumn{2}{|l|}{ RCT: 1991 to 1997} \\
\hline Participants & \multicolumn{2}{|l|}{$\begin{array}{l}488 \text { patients } \\
\text { Stage II-IIIA }\end{array}$} \\
\hline Interventions & \multicolumn{2}{|c|}{$\begin{array}{l}\text { surgery + radiotherapy vs surgery + radiotherapy + chemotherapy } \\
\text { cisplatin } 60 \mathrm{mg} / \mathrm{m}^{2} \\
\text { etoposide } 360 \mathrm{mg} / \mathrm{m}^{2} \\
4 \text { cycles of chemotherapy given concomitantly with radiotherapy } \\
\text { radiotherapy } 56 \mathrm{~Gy} \text { in } 28 \text { fractions } \\
\text { complete resection }\end{array}$} \\
\hline Outcomes & \multicolumn{2}{|c|}{$\begin{array}{l}\text { Overall survival } \\
\text { Recurrence-free survival }\end{array}$} \\
\hline \multicolumn{3}{|l|}{ Notes } \\
\hline \multicolumn{3}{|l|}{ Risk of bias } \\
\hline Bias & Authors' judgement & Support for judgement \\
\hline $\begin{array}{l}\text { Random sequence generation (selection } \\
\text { bias) }\end{array}$ & Low risk & $\begin{array}{l}\text { Data checks on IPD provided suggest adequate sequence gener- } \\
\text { ation }\end{array}$ \\
\hline Allocation concealment (selection bias) & Low risk & Central randomisation \\
\hline Selective reporting (reporting bias) & Low risk & IPD supplied for outcomes \\
\hline
\end{tabular}


B05 INT 0115 (Continued)

Blinding of participants and personnel Low risk (performance bias)

All outcomes

Blinding of outcome assessment (detection Low risk bias)

All outcomes
Trial not blinded due to nature of intervention, outcome not likely to be influenced by lack of blinding

Trial not blinded due to nature of intervention, outcome not likely to be influenced by lack of blinding

B06 ALPI2

\begin{tabular}{|c|c|c|}
\hline Methods & \multicolumn{2}{|l|}{ RCT 1994-99 } \\
\hline Participants & \multicolumn{2}{|l|}{$\begin{array}{l}470 \text { patients } \\
\text { Stage I-IIIA }\end{array}$} \\
\hline Interventions & \multicolumn{2}{|c|}{$\begin{array}{l}\text { surgery }+ \text { radiotherapy vs surgery + radiotherapy + chemotherapy } \\
\text { cisplatin } 100 \mathrm{mg} / \mathrm{m}^{2} \\
\text { vindesine } 6 \mathrm{mg} / \mathrm{m}^{2} \\
\text { mitomycin c } 8 \mathrm{mg} / \mathrm{m}^{2} \\
3 \text { cycles of chemotherapy given before radiotherapy } \\
\text { radiotherapy } 50-54 \text { Gy in } 25-27 \text { fractions } \\
\text { complete resection }\end{array}$} \\
\hline Outcomes & \multicolumn{2}{|c|}{$\begin{array}{l}\text { Overall survival } \\
\text { Recurrence-free survival } \\
\text { Toxicity }\end{array}$} \\
\hline Notes & \multicolumn{2}{|c|}{1088 patients analysed, 470 patients relevant to this trial comparison } \\
\hline \multicolumn{3}{|l|}{ Risk of bias } \\
\hline Bias & Authors' judgement & Support for judgement \\
\hline $\begin{array}{l}\text { Random sequence generation (selection } \\
\text { bias) }\end{array}$ & Low risk & $\begin{array}{l}\text { Data checks on IPD provided suggest adequate sequence gener- } \\
\text { ation }\end{array}$ \\
\hline Allocation concealment (selection bias) & Low risk & Central randomisation \\
\hline Selective reporting (reporting bias) & Low risk & IPD supplied for outcomes \\
\hline $\begin{array}{l}\text { Blinding of participants and personnel } \\
\text { (performance bias) } \\
\text { All outcomes }\end{array}$ & Low risk & $\begin{array}{l}\text { Trial not blinded due to nature of intervention, outcome not } \\
\text { likely to be influenced by lack of blinding }\end{array}$ \\
\hline $\begin{array}{l}\text { Blinding of outcome assessment (detection } \\
\text { bias) } \\
\text { All outcomes }\end{array}$ & Low risk & $\begin{array}{l}\text { Trial not blinded due to nature of intervention, primary outcome } \\
\text { not likely to be influenced by lack of blinding }\end{array}$ \\
\hline
\end{tabular}

Adjuvant chemotherapy for resected early-stage non-small cell lung cancer (Review) 
B07 IALT3

\begin{tabular}{|c|c|c|}
\hline Methods & \multicolumn{2}{|l|}{ RCT: 1995 to 2001} \\
\hline Participants & \multicolumn{2}{|l|}{$\begin{array}{l}1001 \text { patients } \\
\text { Stage I-III }\end{array}$} \\
\hline Interventions & \multicolumn{2}{|c|}{$\begin{array}{l}\text { surgery }+ \text { radiotherapy vs surgery }+ \text { radiotherapy }+ \text { chemotherapy } \\
\text { cisplatin }\left(80,100 \text { or } 120 \mathrm{mg} / \mathrm{m}^{2}\right) \text { and vindesine } 3 \mathrm{mg} / \mathrm{m}^{2} \\
\text { or } \\
\text { vinblastine } 8 \mathrm{mg} / \mathrm{m}^{2} \\
\text { or } \\
\text { etoposide } 300 \mathrm{mg} / \mathrm{m}^{2} \\
3 \text { or } 4 \text { cycles of chemotherapy given before radiotherapy } \\
\text { radiotherapy }<60 \text { Gy } \\
\text { complete resection }\end{array}$} \\
\hline Outcomes & \multicolumn{2}{|c|}{$\begin{array}{l}\text { Overall survival } \\
\text { Recurrence-free survival } \\
\text { Causes of death }\end{array}$} \\
\hline Notes & \multicolumn{2}{|c|}{1867 patients randomised to trial, 366 patients relevant to this trial comparison } \\
\hline \multicolumn{3}{|l|}{ Risk of bias } \\
\hline Bias & Authors' judgement & Support for judgement \\
\hline $\begin{array}{l}\text { Random sequence generation (selection } \\
\text { bias) }\end{array}$ & Low risk & $\begin{array}{l}\text { Data checks on IPD provided suggest adequate sequence gener- } \\
\text { ation }\end{array}$ \\
\hline Allocation concealment (selection bias) & Low risk & Central randomisation \\
\hline Selective reporting (reporting bias) & Low risk & IPD supplied for outcomes \\
\hline $\begin{array}{l}\text { Blinding of participants and personnel } \\
\text { (performance bias) } \\
\text { All outcomes }\end{array}$ & Low risk & $\begin{array}{l}\text { Trial not blinded due to nature of intervention, outcome not } \\
\text { likely to be influenced by lack of blinding }\end{array}$ \\
\hline $\begin{array}{l}\text { Blinding of outcome assessment (detection } \\
\text { bias) } \\
\text { All outcomes }\end{array}$ & Low risk & $\begin{array}{l}\text { Trial not blinded due to nature of intervention, outcome not } \\
\text { likely to be influenced by lack of blinding }\end{array}$ \\
\hline
\end{tabular}

\section{B08 BLT4}

Methods

RCT: 1995 to 2001

Participants

49 patients

Stage I-III 
B08 BLT4 (Continued)

\begin{tabular}{ll}
\hline Interventions & $\begin{array}{l}\text { surgery }+ \text { radiotherapy vs surgery + radiotherapy + chemotherapy } \\
\text { cisplatin }\left(80,100 \mathrm{or} 120 \mathrm{mg} / \mathrm{m}^{2}\right) \text { and vindesine } \\
\text { mitomycin c } 8 \mathrm{mg} / \mathrm{m}^{2}\end{array}$ \\
$\begin{array}{l}3 \text { cycles of chemotherapy given before radiotherapy } \\
\text { radiotherapy }<60 \mathrm{~Gy} \\
\text { complete resection }\end{array}$ \\
\hline Outcomes & $\begin{array}{l}\text { Overall survival } \\
\text { Recurrence-free survival }\end{array}$ \\
\hline Notes & \begin{tabular}{l}
381 patients randomised to trial, 49 patients relevant to this trial comparison \\
\hline
\end{tabular}
\end{tabular}

\section{Risk of bias}

\begin{tabular}{l|l|l} 
Bias & Authors' judgement & Support for judgement \\
\hline $\begin{array}{l}\text { Random sequence generation (selection } \\
\text { bias) }\end{array}$ & Low risk & $\begin{array}{l}\text { Data checks on IPD provided suggest adequate sequence gener- } \\
\text { ation }\end{array}$ \\
\hline $\begin{array}{l}\text { Allocation concealment (selection bias) } \\
\text { Selective reporting (reporting bias) }\end{array}$ & Low risk & Lentral randomisation \\
\hline $\begin{array}{l}\text { Blinding of participants and personnel } \\
\text { (performance bias) } \\
\text { All outcomes }\end{array}$ & Low risk & IPD supplied for outcomes \\
\hline $\begin{array}{l}\text { Blinding of outcome assessment (detection } \\
\text { bias) } \\
\text { All outcomes }\end{array}$ & Low risk & $\begin{array}{l}\text { Trial not blinded due to nature of intervention, outcome not } \\
\text { likely to be influenced by lack of blinding }\end{array}$ \\
\hline
\end{tabular}

B09 ANITA2

Methods

Participants

Stage IB-IIIA

Interventions

Outcomes

377 patients

Stage IB-IIIA
RCT: 1994 to 2000

surgery + radiotherapy vs surgery + radiotherapy + chemotherapy

cisplatin $100 \mathrm{mg} / \mathrm{m}^{2}$

vinorelbine $120 \mathrm{mg} / \mathrm{m}^{2}$

4 cycles of chemotherapy given before radiotherapy

radiotherapy 45-60 Gy in 23-30 fractions

complete resection

Overall survival

Recurrence-free survival 
B09 ANITA2 (Continued)

Notes

840 patients randomised in trial, 377 patients relevant to this trial comparison

Risk of bias

\begin{tabular}{l|l|l}
\hline Bias & Authors judgement & Support for judgement \\
\hline $\begin{array}{l}\text { Random sequence generation (selection } \\
\text { bias) }\end{array}$ & Low risk & $\begin{array}{l}\text { Data checks on IPD provided suggest adequate sequence gener- } \\
\text { ation }\end{array}$ \\
\hline Allocation concealment (selection bias) & Low risk & Central randomisation \\
\hline $\begin{array}{l}\text { Selective reporting (reporting bias) } \\
\text { Blinding of participants and personnel } \\
\begin{array}{l}\text { (performance bias) } \\
\text { All outcomes }\end{array}\end{array}$ & Low risk & IPD supplied for outcomes \\
\hline $\begin{array}{l}\text { Blinding of outcome assessment (detection } \\
\text { bias) } \\
\text { All outcomes }\end{array}$ & Low risk & $\begin{array}{l}\text { Trial not blinded due to nature of intervention, outcome not } \\
\text { likely to be influenced by lack of blinding }\end{array}$ \\
\hline
\end{tabular}

B10 IALT4

\begin{tabular}{l|l}
\hline Methods & RCT: 1994 to 2001 \\
\hline Participants & $\begin{array}{l}206 \text { patients } \\
\text { Stage I-III }\end{array}$ \\
\hline Interventions & $\begin{array}{l}\text { surgery }+ \text { radiotherapy vs surgery + radiotherapy + chemotherapy } \\
\text { cisplatin }\left(80,100 \text { or } 120 \mathrm{mg} / \mathrm{m}^{2}\right) \\
\text { vinorelbine } 30 \mathrm{mg} / \mathrm{m}^{2} \\
\text { 3 or } 4 \text { cycles of chemotherapy given before radiotherapy } \\
\text { radiotherapy }<60 \mathrm{~Gy} \\
\text { complete resection }\end{array}$ \\
\hline Outcomes & $\begin{array}{l}\text { Overall survival } \\
\text { Recurrence-free survival } \\
\text { Causes of death }\end{array}$ \\
\hline Notes & \begin{tabular}{l}
1867 patients randomised in trial, 206 patients relevant to this trial comparison \\
\hline
\end{tabular}
\end{tabular}

\section{Risk of bias}

Bias

Random sequence generation (selection Low risk bias)
Authors' judgement Support for judgement

Data checks on IPD provided suggest adequate sequence generation 
B10 IALT4

(Continued)

\begin{tabular}{|c|c|c|}
\hline Allocation concealment (selection bias) & Low risk & Central randomisation \\
\hline Selective reporting (reporting bias) & Low risk & IPD supplied for outcomes \\
\hline $\begin{array}{l}\text { Blinding of participants and personnel } \\
\text { (performance bias) } \\
\text { All outcomes }\end{array}$ & Low risk & $\begin{array}{l}\text { Trial not blinded due to nature of intervention, outcome not } \\
\text { likely to be influenced by lack of blinding }\end{array}$ \\
\hline $\begin{array}{l}\text { Blinding of outcome assessment (detection } \\
\text { bias) } \\
\text { All outcomes }\end{array}$ & Low risk & $\begin{array}{l}\text { Trial not blinded due to nature of intervention, primary outcome } \\
\text { not likely to be influenced by lack of blinding }\end{array}$ \\
\hline
\end{tabular}

\section{B11 LCSG 791}

\begin{tabular}{l|l}
\hline Methods & RCT: 1979 to 85 \\
\hline Participants & $\begin{array}{l}172 \text { patients } \\
\text { Stage I-III }\end{array}$ \\
\hline Interventions & $\begin{array}{l}\text { surgery }+ \text { radiotherapy vs surgery + radiotherapy + chemotherapy } \\
\text { cyclophosphamide } 400 \mathrm{mg} / \mathrm{m}^{2} \\
\text { doxorubicin } 40 \mathrm{mg} / \mathrm{m}^{2} \\
\text { cisplatin } 40 \mathrm{mg} / \mathrm{m}^{2} \\
\text { 6 cycles of chemotherapy, concomitant chemotherapy-radiotherapy for } 1 \text { st } 2 \text { cycles of } \\
\text { chemotherapy } \\
\text { radiotherapy } 40 \mathrm{~Gy} \text { in } 10 \text { fractions } \\
\text { incomplete resection }\end{array}$ \\
\hline Outcomes & Overall survival \\
\hline Notes & \\
\hline
\end{tabular}

\section{Risk of bias}

\section{Bias}

Random sequence generation (selection Low risk bias)

\begin{tabular}{l|ll}
\hline Allocation concealment (selection bias) & Low risk & Central randomisation \\
\hline Selective reporting (reporting bias) & Low risk & IPD supplied for outcomes \\
\hline $\begin{array}{l}\text { Blinding of participants and personnel } \\
\text { (performance bias) } \\
\text { All outcomes }\end{array}$ & Low risk & $\begin{array}{l}\text { Trial not blinded due to nature of intervention, outcome not } \\
\text { likely to be influenced by lack of blinding }\end{array}$
\end{tabular}


B11 LCSG 791 (Continued)

Blinding of outcome assessment (detection Low risk bias)

All outcomes
Trial not blinded due to nature of intervention, outcome not likely to be influenced by lack of blinding

B12 FLCSG 3

\begin{tabular}{ll}
\hline Methods & RCT: 1982 to 1987 \\
\hline Participants & $\begin{array}{l}86 \text { patients } \\
\text { Stage I-III }\end{array}$ \\
\hline Interventions & $\begin{array}{l}\text { surgery + radiotherapy vs surgery + radiotherapy + chemotherapy } \\
\text { cyclophoshamide } 400 \mathrm{mg} / \mathrm{m}^{2} \\
\text { doxorubicin } 40 \mathrm{mg} / \mathrm{m}^{2} \\
\text { cisplatin } 40 \mathrm{mg} / \mathrm{m}^{2} \\
8 \text { cycles of chemotherapy, } 2 \text { given before radiotherapy } \\
\text { radiotherapy } 55 \mathrm{~Gy} \text { in } 20 \text { fractions } \\
\text { incomplete resection }\end{array}$ \\
\hline Outcomes & Overall survival \\
\hline Notes & unpublished \\
\hline
\end{tabular}

Risk of bias

Bias

Authors' judgement Support for judgement

Random sequence generation (selection Low risk bias)

Data checks on IPD provided suggest adequate sequence generation

\begin{tabular}{lll} 
Allocation concealment (selection bias) & Low risk & Sealed envelope \\
\hline Selective reporting (reporting bias) & Low risk & IPD supplied for outcomes
\end{tabular}

Blinding of participants and personnel Low risk (performance bias)

Trial not blinded due to nature of intervention, outcome not All outcomes

likely to be influenced by lack of blinding

Blinding of outcome assessment (detection Low risk bias)

Trial not blinded due to nature of intervention, outcome not likely to be influenced by lack of blinding

All outcomes 
B13 OLCSG1d

\begin{tabular}{|c|c|c|}
\hline Methods & \multicolumn{2}{|l|}{ RCT: 1983 to 1987} \\
\hline Participants & \multicolumn{2}{|l|}{$\begin{array}{l}49 \text { patients } \\
\text { Stage III }\end{array}$} \\
\hline Interventions & \multicolumn{2}{|c|}{$\begin{array}{l}\text { surgery }+ \text { radiotherapy vs surgery }+ \text { radiotherapy }+ \text { chemotherapy } \\
\text { cisplatin } 80 \mathrm{mg} / \mathrm{m}^{2} \text { (given once) } \\
\text { tegafur* } 600-800 \mathrm{mg} / \mathrm{m}^{2} \text { (daily treatment) } \\
\text { chemotherapy before radiotherapy, unknown number of cycles of chemotherapy } \\
\text { radiotherapy } 40 \mathrm{~Gy} \text { in } 20 \text { fractions } \\
\text { complete resection }\end{array}$} \\
\hline Outcomes & \multicolumn{2}{|l|}{ Overall survival } \\
\hline \multicolumn{3}{|l|}{ Notes } \\
\hline \multicolumn{3}{|l|}{ Risk of bias } \\
\hline Bias & Authors' judgement & Support for judgement \\
\hline $\begin{array}{l}\text { Random sequence generation (selection } \\
\text { bias) }\end{array}$ & Low risk & $\begin{array}{l}\text { Data checks on IPD provided suggest adequate sequence gener- } \\
\text { ation }\end{array}$ \\
\hline Allocation concealment (selection bias) & Low risk & Sealed envelope \\
\hline Selective reporting (reporting bias) & Low risk & IPD supplied for outcomes \\
\hline $\begin{array}{l}\text { Blinding of participants and personnel } \\
\text { (performance bias) } \\
\text { All outcomes }\end{array}$ & Low risk & $\begin{array}{l}\text { Trial not blinded due to nature of intervention, outcome not } \\
\text { likely to be influenced by lack of blinding }\end{array}$ \\
\hline $\begin{array}{l}\text { Blinding of outcome assessment (detection } \\
\text { bias) } \\
\text { All outcomes }\end{array}$ & Low risk & $\begin{array}{l}\text { Trial not blinded due to nature of intervention, primary outcome } \\
\text { not likely to be influenced by lack of blinding }\end{array}$ \\
\hline
\end{tabular}

Gy - Gray, unit of radiotherapy dose

IPD - Individual participant data

NK - not known

N/A - not available

UFT - Uracil/tegafur

RCT - randomised controlled trial 
Characteristics of excluded studies [ordered by study ID]

\begin{tabular}{|c|c|}
\hline Study & Reason for exclusion \\
\hline Ayoub 1991 & Data not available \\
\hline Clerici 1991 & Data not available \\
\hline EORTC 08922 & Data not available \\
\hline Ichinose 1991 & Data not available \\
\hline Kim 2003 & No contact with trialist established \\
\hline NCCTG 852451 & Data not available \\
\hline Ueda 2004 & No contact with trialist established \\
\hline Wang 2009 & Trial discovered too late to be included in this analysis \\
\hline Wolf 2001 & No contact with trialist established \\
\hline Wu 2009 & Trial discovered too late to be included in this analysis \\
\hline Zarogoulidis 1996 & No contact with trialist established \\
\hline
\end{tabular}

Characteristics of studies awaiting assessment [ordered by study ID]

\section{NATCH 2010}

\begin{tabular}{ll}
\hline Methods & Randomised controlled trial \\
\hline Participants & 423 patients relevant \\
\hline Interventions & Surgery + chemotherapy vs surgery \\
\hline Outcomes & Recurrence-free survival \\
\hline Notes & \\
\hline
\end{tabular}

\section{Zheng 2011}

\begin{tabular}{ll}
\hline Methods & Randomised controlled trial \\
\hline Participants & 70 patients \\
\hline
\end{tabular}

Interventions Surgery + chemotherapy vs surgery 
Zheng 2011 (Continued)

Outcomes Overall survival

Notes

Characteristics of ongoing studies [ordered by study ID]

\section{CALGB 30506}

Trial name or title CALGB 30506: Phase III randomised study of adjuvant chemotherapy versus observation in patients with early stage non-small cell lung cancer

\begin{tabular}{ll}
\hline Methods & Randomised controlled trial \\
\hline Participants & 1620 patients planned \\
\hline Interventions & Surgery + chemotherapy vs surgery \\
\hline Outcomes & Overall survival \\
\hline Starting date & March 2009 \\
\hline Contact information & Protocol Chair: David Harpole MD \\
\hline Notes & Estimated completion date, Jan 2014 \\
\hline
\end{tabular}


DATA ANDANALYSES

Comparison 1. Surgery versus surgery + adjuvant chemotherapy

\begin{tabular}{|c|c|c|c|c|}
\hline Outcome or subgroup title & $\begin{array}{l}\text { No. of } \\
\text { studies }\end{array}$ & $\begin{array}{c}\text { No. of } \\
\text { participants }\end{array}$ & Statistical method & Effect size \\
\hline 1 Survival & 34 & & Hazard Ratio (95\% CI) & Subtotals only \\
\hline $\begin{array}{l}\text { 1.1 Platinum + vinca } \\
\text { alkaloid/etoposide }\end{array}$ & 9 & 2404 & Hazard Ratio (95\% CI) & $0.94[0.84,1.05]$ \\
\hline 1.2 Platinum + vinorelbine & 4 & 1304 & Hazard Ratio (95\% CI) & $0.82[0.70,0.97]$ \\
\hline 1.3 Platinum + taxane & 1 & 344 & Hazard Ratio (95\% CI) & $0.77[0.57,1.05]$ \\
\hline 1.4 Other platinum regimens & 4 & 699 & Hazard Ratio (95\% CI) & $0.90[0.72,1.13]$ \\
\hline $\begin{array}{l}\text { 1.5 Platinum + vinca alkaloid } \\
+ \text { tegafur and uracil/tegafur }\end{array}$ & 8 & 1375 & Hazard Ratio (95\% CI) & $0.79[0.67,0.93]$ \\
\hline $\begin{array}{l}\text { 1.6 Tegafur and uracil/tegafur } \\
+ \text { other agent }\end{array}$ & 1 & 83 & Hazard Ratio (95\% CI) & $1.79[1.00,3.20]$ \\
\hline 1.7 Tegafur and uracil/tegafur & 7 & 2390 & Hazard Ratio (95\% CI) & $0.76[0.64,0.90]$ \\
\hline
\end{tabular}

Comparison 2. Surgery + radiotherapy versus surgery + radiotherapy + adjuvant chemotherapy

\begin{tabular}{|c|c|c|c|c|}
\hline Outcome or subgroup title & $\begin{array}{l}\text { No. of } \\
\text { studies }\end{array}$ & $\begin{array}{c}\text { No. of } \\
\text { participants }\end{array}$ & Statistical method & Effect size \\
\hline 1 Survival & 13 & 2660 & Hazard Ratio (95\% CI) & $0.88[0.81,0.97]$ \\
\hline $\begin{array}{l}\text { 1.1 Platinum + vinca } \\
\text { alkaloid/etoposide }\end{array}$ & 8 & 1770 & Hazard Ratio $(95 \%$ CI) & $0.93[0.83,1.03]$ \\
\hline 1.2 Platinum + vinorelbine & 2 & 583 & Hazard Ratio $(95 \%$ CI) & $0.77[0.63,0.94]$ \\
\hline 1.3 Other platinum regimen & 2 & 258 & Hazard Ratio $(95 \%$ CI) & $0.85[0.65,1.11]$ \\
\hline 1.4 Antimetabolic agent only & 1 & 49 & Hazard Ratio (95\% CI) & $1.02[0.45,2.34]$ \\
\hline
\end{tabular}




\section{Analysis I.I. Comparison I Surgery versus surgery + adjuvant chemotherapy, Outcome I Survival.}

Review: Adjuvant chemotherapy for resected early-stage non-small cell lung cancer

Comparison: I Surgery versus surgery + adjuvant chemotherapy

Outcome: I Survival

Study or subgroup

Treatment Control

Hazard Ratio

$\operatorname{Exp}[(\mathrm{O}$ -

E)/ $\mathrm{J}$,Fixed,95\%

Weight

Hazard Ratio $\operatorname{Exp}[(\mathrm{O}-$

$\mathrm{n} / \mathrm{N}$

$\mathrm{n} / \mathrm{N}$ $\mathrm{Cl}$

I Platinum + vinca alkaloid/etoposide

AOI IPCR, Chiba

$11 / 15$

$7 / 14$

A02 JLCSSG

$59 / 111$

$52 / 98$

A03 Mineo

14/33

$21 / 33$

A04 Parkl

17/59

$23 / 59$

A05 Park2

$37 / 53$

$43 / 55$

A06 ALPII

$143 / 310$

144/308

A07 |ALT |

235/499

243/502

A08 BLTI

$34 / 69$

$32 / 67$

A09 JCOG 9304

$33 / 59$

$35 / 60$

Subtotal (95\% CI)

1208

1196

Heterogeneity: $\mathrm{Chi}^{2}=6.35, \mathrm{df}=8(\mathrm{P}=0.6 \mathrm{I}) ; \mathrm{I}^{2}=0.0 \%$

Test for overall effect: $Z=1.10(P=0.27)$

2 Platinum + vinorelbine

$\begin{array}{lcr}\text { AIO ANITAI } & 102 / 231 & 1 \mid 3 / 232 \\ \text { AII JBRIO } & 86 / 242 & 1 \mid 1 / 240 \\ \text { AI2 IALT2 } & 55 / 149 & 61 / 145 \\ \text { AI3 BLT2 } & 15 / 37 & 15 / 28\end{array}$

\section{Subtotal (95\% CI)}

659

645

Heterogeneity: $\mathrm{Chi}^{2}=2.49, \mathrm{df}=3(\mathrm{P}=0.48) ; \mathrm{I}^{2}=0.0 \%$

Test for overall effect: $Z=2.32(P=0.021)$

3 Platinum + taxane

Al4 CALGB 9633

$78 / 173$

93/171

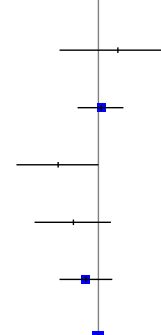

$1.4 \%$

$1.39[0.52,3.66]$

$9.3 \%$

$1.04[0.7|| .5 \mid$,

$2.9 \%$

$0.51[0.26,0.99]$

$3.4 \%$

$0.66[0.35,1.23]$

$6.8 \%$

$0.81[0.52,1.26]$

$24.3 \%$

$40.6 \%$

$1.01[0.80,1.28]$

$0.6 \%$

$0.94[0.78,1.12]$

$5.6 \%$

$1.03[0.64,1.68]$

$5.8 \%$

$0.97[0.61,1.57]$

$100.0 \%$

0.94 [ $0.84,1.05$ ]

Subtotal (95\% CI)

173

171

$100.0 \%$

$0.77[0.57,1.05]$

Heterogeneity: not applicable

Test for overall effect: $Z=1.67(P=0.095)$

4 Other platinum regimens

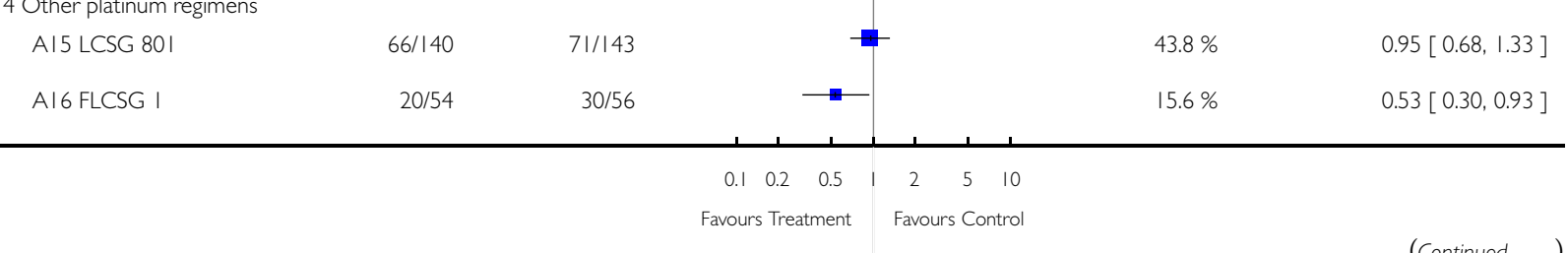

(Continued ....)

Adjuvant chemotherapy for resected early-stage non-small cell lung cancer (Review) 


\begin{tabular}{|c|c|c|c|c|c|}
\hline Study or subgroup & Treatment & $\begin{array}{r}\text { Control } \\
n / N \\
\end{array}$ & $\begin{array}{c}\text { Hazard Ratio } \\
\text { Exp[(O- } \\
\text { E) } / \mathrm{O}] \text {,Fixed,95\% } \\
\mathrm{Cl}\end{array}$ & Weight & $\begin{array}{r}\text { Hazard Ratio } \\
\text { Exp[(O- } \\
\text { E) } N \mathrm{~V} \text {,Fixed,95\% } \\
\mathrm{Cl} \\
\end{array}$ \\
\hline AI7 LCSG 853 & $29 / 94$ & $32 / 94$ & $\rightarrow$ & $19.5 \%$ & $0.90[0.54,1.48]$ \\
\hline AI8 BLT3 & $34 / 56$ & $34 / 62$ & t & $21.0 \%$ & $1.22[0.75,1.97]$ \\
\hline Subtotal $(95 \% \mathrm{CI})$ & 344 & 355 & $\bullet$ & $100.0 \%$ & $0.90[0.72,1.13]$ \\
\hline \multicolumn{6}{|c|}{ Heterogeneity: Chi $^{2}=5.04, d f=3(P=0.17) ; 1^{2}=41 \%$} \\
\hline \multicolumn{6}{|c|}{ Test for overall effect: $Z=0.91 \quad(P=0.36)$} \\
\hline \multicolumn{6}{|c|}{5 Platinum + vinca alkaloid + tegafur and uracil/tegafur } \\
\hline AI9 SGACLC ACTLCI & $68 / 154$ & $75 / 152$ & - & $24.9 \%$ & $0.82[0.59,1.14]$ \\
\hline A20 OLCSGIC & $5 / 12$ & $7 / 16$ & & $2.0 \%$ & $0.94[0.30,2.95]$ \\
\hline A2I SGACLC ACTLC2 & $64 / 165$ & $68 / 167$ & $\rightarrow$ & $23.0 \%$ & $0.86[0.61,1.22]$ \\
\hline A22 WJSG $2(1+3)$ & $44 / 115$ & $49 / 100$ & $\rightarrow$ & $16.0 \%$ & $0.72[0.48,1.08]$ \\
\hline A23 WJSG3 & $27 / 109$ & $40 / 116$ & $\longrightarrow$ & $11.7 \%$ & $0.70[0.43,1.13]$ \\
\hline $\mathrm{A} 24 \mathrm{Xu}$ & $19 / 35$ & $26 / 35$ & $\square$ & $7.8 \%$ & $0.66[0.37,1.18]$ \\
\hline A25 ACTLC4a & $10 / 52$ & $18 / 52$ & . & $4.8 \%$ & $0.47[0.22,0.99]$ \\
\hline A26 OLCSG2b & $28 / 47$ & $28 / 48$ & & $9.7 \%$ & $1.19[0.70,2.01]$ \\
\hline Subtotal $(95 \% \mathrm{CI})$ & 689 & 686 & $\bullet$ & $100.0 \%$ & $0.79[0.67,0.93]$ \\
\hline \multicolumn{6}{|c|}{ Heterogeneity: Chi $^{2}=5.40, d f=7(P=0.61) ; 1^{2}=0.0 \%$} \\
\hline \multicolumn{6}{|c|}{ Test for overall effect: $Z=2.78(P=0.0054)$} \\
\hline \multicolumn{6}{|c|}{6 Tegafur and uracil/tegafur + other agent } \\
\hline A27 OLCSGIb & $27 / 41$ & $21 / 42$ & & $100.0 \%$ & $1.79[1.00,3.20]$ \\
\hline Subtotal $(95 \% \mathrm{CI})$ & 41 & 42 & - & $100.0 \%$ & $1.79[1.00,3.20]$ \\
\hline \multicolumn{6}{|l|}{ Heterogeneity: not applicable } \\
\hline \multicolumn{6}{|c|}{ Test for overall effect: $Z=1.96(P=0.05 \mathrm{I})$} \\
\hline \multicolumn{6}{|l|}{7 Tegafur and uracil/tegafur } \\
\hline A28 OLCSGIa & $30 / 163$ & $28 / 158$ & $\rightarrow$ & $10.8 \%$ & $0.99[0.59,1.66]$ \\
\hline A29 WJSG2 (2+3) & $38 / 108$ & $49 / 100$ & $\rightarrow$ & $16.0 \%$ & $0.63[0.42,0.97]$ \\
\hline A30 WJSG4 & $38 / 176$ & $56 / 191$ & $\rightarrow$ & $17.4 \%$ & $0.78[0.52,1.17]$ \\
\hline A3I NJSGLCS & $24 / 109$ & $27 / 110$ & $\longrightarrow$ & $9.5 \%$ & $0.90[0.52,1.56]$ \\
\hline A32 OLCSG2a & $20 / 85$ & $35 / 87$ & $\longrightarrow$ & $10.2 \%$ & $0.58[0.34,0.99]$ \\
\hline A33 ACTLC4b & $17 / 52$ & $18 / 52$ & $\longrightarrow$ & $6.5 \%$ & $0.94[0.48,1.82]$ \\
\hline A34 JLCRG & $67 / 498$ & $9 \mid / 501$ & $\rightarrow$ & $29.5 \%$ & $0.74[0.54,1.02]$ \\
\hline Subtotal $(95 \% \mathrm{CI})$ & 1191 & 1199 & $\bullet$ & $100.0 \%$ & $0.76[0.64,0.90]$ \\
\hline \multicolumn{6}{|c|}{ Heterogeneity: $\mathrm{Ch}^{2} \mathrm{I}^{2}=3.49, \mathrm{df}=6(\mathrm{P}=0.74) ; \mathrm{I}^{2}=0.0 \%$} \\
\hline \multicolumn{6}{|c|}{ Test for overall effect: $Z=3.18(P=0.0015)$} \\
\hline Test for subgroup difference & $=12.25, \mathrm{df}=$ & .06), $\left.\right|^{2}=51 \%$ & & & \\
\hline
\end{tabular}




\section{Analysis 2.1. Comparison 2 Surgery + radiotherapy versus surgery + radiotherapy + adjuvant chemotherapy, Outcome I Survival.}

Review: Adjuvant chemotherapy for resected early-stage non-small cell lung cancer

Comparison: 2 Surgery + radiotherapy versus surgery + radiotherapy + adjuvant chemotherapy

Outcome: I Survival

Treatment

Control

Hazard Ratio E) $N$ ],Fixed,95\%

I Platinum + vinca alkaloid/etoposide

BOI MSKCC 80-53

$\mathrm{n} / \mathrm{N}$

, $N$,Fixed, $95 \%$

B02 GETCB O ICB82

$34 / 36$

$34 / 36$

B03 EORTC 0886 ।

$125 / 138$

1 15/129

B04 MDA DM 87045

$5 / 10$

$8 / 14$

B05 INT 0I I5

$15 / 16$

$18 / 18$

B06 ALPI2

183/246

186/242

B07 IALT3

$136 / 238$

146/232

B08 BLT4

125/185

|33/|8|

Subtotal $(\mathbf{9 5} \% \mathrm{CI})$

15/23

18/26

892

878

Heterogeneity: Chi $^{2}=1.26, \mathrm{df}=7(\mathrm{P}=0.99) ; \mathrm{I}^{2}=0.0 \%$

Test for overall effect: $Z=1.39(P=0.16)$

2 Platinum + vinorelbine

$\begin{array}{lll}\text { B09 ANITA2 139/20I } & \text { 104/176 }\end{array}$

BIOIALT4 $\quad 59 / 107$

Subtotal (95\% CI)

$275 \quad 308$

Heterogeneity: Chi $^{2}=1.46, \mathrm{df}=1(P=0.23) ;\left.\right|^{2}=32 \%$

Test for overall effect: $Z=2.51(P=0.012)$

3 Other platinum regimen

$\begin{array}{lcc}\text { BII LCSG 79| } & 68 / 82 & 75 / 90 \\ \text { BI2 FLCSG 3 } & 34 / 40 & 42 / 46 \\ \text { Subtotal (95\% CI) } & \mathbf{1 2 2} & \mathbf{1 3 6}\end{array}$

Heterogeneity: $\mathrm{Ch}^{2}=0.00, \mathrm{df}=\mathrm{I}(\mathrm{P}=0.98) ; \mathrm{I}^{2}=0.0 \%$

Test for overall effect: $Z=1.20(P=0.23)$

4 Antimetabolic agent only

BI3 OLCSGId

$13 / 26$

26

$10 / 23$

Subtotal (95\% CI)

23

\begin{tabular}{cr} 
Weight & $\begin{array}{r}\text { Hazard Ratio } \\
\text { Exp }[(\mathrm{O}- \\
\text { E) } / \mathrm{F}, \text { Fixed,95\% } \\
\mathrm{Cl}\end{array}$ \\
\hline $3.5 \%$ & $1.12[0.69,1.81]$ \\
$12.5 \%$ & $0.93[0.72,1.21]$ \\
$0.6 \%$ & $1.04[0.34,3.26]$ \\
$1.7 \%$ & $0.84[0.42,1.67]$ \\
$19.5 \%$ & $0.96[0.79,1.18]$ \\
$14.9 \%$ & $0.87[0.69,1.10]$ \\
$13.6 \%$ & $0.89[0.70,1.14]$ \\
$1.7 \%$ & $0.94[0.47,1.89]$
\end{tabular}

$67.8 \%$

$0.93[0.83,1.03$ ]

$12.8 \%$

$0.70[0.55,0.90]$

$6.7 \%$

$0.92[0.65,1.30]$

$19.5 \%$

$0.77[0.63,0.94]$

$7.5 \%$

$0.85[0.61,1.18]$

$4.0 \%$

$0.84[0.54,1.33]$

$11.5 \%$

$0.85[0.65,1.11]$

$1.2 \%$

$1.02[0.45,2.34]$

$1.2 \%$

$1.02[0.45,2.34]$

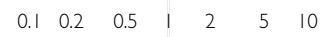

Favours Treatment Favours Control

(Continued....) 


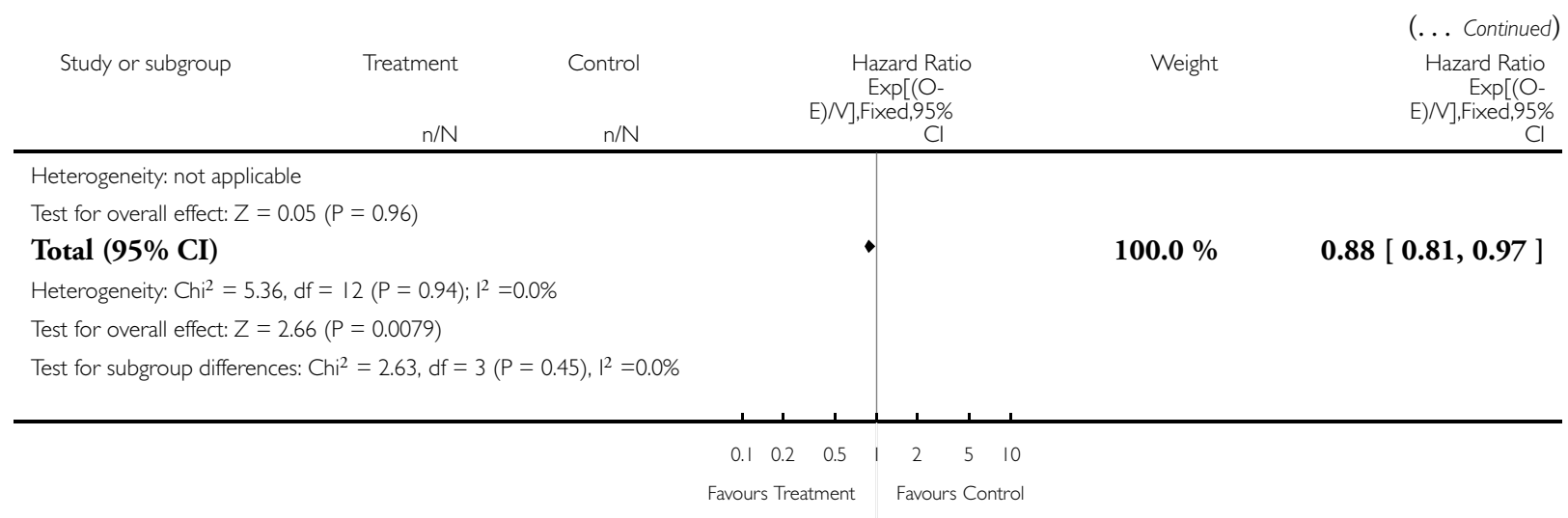

\section{ADDITIONAL TABLES}

Table 1. Recent meta-analyses of surgery (+/- radiotherapy) + chemotherapy versus surgery (+/- radiotherapy)

\begin{tabular}{|c|c|c|c|c|c|}
\hline Author & Type of data & Number of trials & Number of patients & Outcome & $\begin{array}{l}\text { Hazard Ratio ( } 95 \% \\
\text { CI) }\end{array}$ \\
\hline Hotta 2004 & Published data & $11^{*}$ & 5716 & Survival & 0.87 (0.81 to 0.94$)$ \\
\hline Sedrakyan 2004 & Published data & 19 & 7200 & Survival & 0.87 (0.81 to 0.93$)$ \\
\hline Berghmans 2005 & Published data & 17 & 7644 & Survival & $0.85(0.79$ to 0.91$)$ \\
\hline Bria 2005 & Published data & $11+1$ meta-analysis & 6494 & Survival & $0.93(0.89$ to 0.95$)$ \\
\hline Hamada 2005 & $\begin{array}{l}\text { Individual } \\
\text { participant data }\end{array}$ & $6^{* *}$ & 2003 & Survival & $0.74(0.61$ to 0.88$)$ \\
\hline Pignon 2008 & $\begin{array}{l}\text { Individual } \\
\text { participant data }\end{array}$ & $5 \dagger$ & 4584 & $\begin{array}{l}\text { Survival } \\
\text { Event-free survival }\end{array}$ & $\begin{array}{l}0.89(0.82 \text { to } 0.96) \\
0.84(0.78 \text { to } 0.91)\end{array}$ \\
\hline
\end{tabular}

* Recent trials only

**UFT trials only

$\dagger$ Large (> 300 patients) and recent cisplatin trials only 
Table 2. Patient characteristics for trials of surgery + chemotherapy versus surgery and for trials of surgery + radiotherapy + chemotherapy versus surgery + radiotherapy

\begin{tabular}{|c|c|c|c|c|}
\hline Characteristic & $\begin{array}{l}\text { Surgery + CT* } \\
(\mathrm{n}=4305)\end{array}$ & $\begin{array}{l}\text { Surgery } \\
(\mathrm{n}=4142)\end{array}$ & $\begin{array}{l}\text { Surgery + RT } \\
(\mathbf{n}=1315)\end{array}$ & $\begin{array}{l}\text { Surgery + RT } \\
(\mathrm{n}=1345)\end{array}$ \\
\hline \multicolumn{5}{|l|}{ Age (years) } \\
\hline$<60$ & $1827(46 \%)$ & $1669(44 \%)$ & $692(53 \%)$ & $693(51 \%)$ \\
\hline $60-64$ & $898(17 \%)$ & $900(18 \%)$ & $270(20 \%)$ & $292(22 \%)$ \\
\hline $65-69$ & $872(20 \%)$ & $878(21 \%)$ & $253(19 \%)$ & $253(19 \%)$ \\
\hline$>=70$ & $593(14 \%)$ & $583(14 \%)$ & $100(8 \%)$ & $107(8 \%)$ \\
\hline Unknown & $115(3 \%)$ & $112(3 \%)$ & - & - \\
\hline \multicolumn{5}{|l|}{ Sex } \\
\hline Male & $2948(68 \%)$ & $2876(69 \%)$ & $1023(78 \%)$ & $1062(79 \%)$ \\
\hline Female & $1238(29 \%)$ & $1149(28 \%)$ & $291(22 \%)$ & $281(21 \%)$ \\
\hline Unknown & $119(3 \%)$ & $117(3 \%)$ & $1(<1 \%)$ & $2(<1 \%)$ \\
\hline \multicolumn{5}{|l|}{ Histology } \\
\hline Adenocarcinoma & $2257(52 \%)$ & $2158(52 \%)$ & $499(38 \%)$ & $501(37 \%)$ \\
\hline Squamous & $1649(38 \%)$ & $1587(38 \%)$ & $642(49 \%)$ & $655(49 \%)$ \\
\hline Other & $386(9 \%)$ & $391(9 \%)$ & $172(13 \%)$ & $184(14 \%)$ \\
\hline Unknown & $13(<1 \%)$ & $6(<1 \%)$ & $2(<1 \%)$ & $5(<1)$ \\
\hline \multicolumn{5}{|l|}{ Stage } \\
\hline I & $2851(66 \%)$ & $2772(67 \%)$ & $20(2 \%)$ & $14(1 \%)$ \\
\hline II & $806(19 \%)$ & $793(19 \%)$ & $450(34 \%)$ & $473(35 \%)$ \\
\hline IIIa & $586(14 \%)$ & $512(12 \%)$ & $804(61 \%)$ & $801(60 \%)$ \\
\hline IIIb & $31(<1 \%)$ & $42(1 \%)$ & $21(2 \%)$ & $30(2 \%)$ \\
\hline Stage III Unspecified & - & - & - & $3(<1 \%)$ \\
\hline IV & $13(<1 \%)$ & $10(<1 \%)$ & $3(<1 \%)$ & $0(0 \%)$ \\
\hline
\end{tabular}


Table 2. Patient characteristics for trials of surgery + chemotherapy versus surgery and for trials of surgery + radiotherapy + chemotherapy versus surgery + radiotherapy (Continued)

\begin{tabular}{|c|c|c|c|c|}
\hline Unknown & $18(<1 \%)$ & $13(<1 \%)$ & $17(1 \%)$ & $24(2 \%)$ \\
\hline \multicolumn{5}{|l|}{ Performance status $\dagger$} \\
\hline Good & $3172(74 \%)$ & $3022(73 \%)$ & $948(72 \%)$ & $969(72 \%)$ \\
\hline Poor & $96(2 \%)$ & $83(2 \%)$ & $81(6 \%)$ & $105(8 \%)$ \\
\hline Unknown & $76(2 \%)$ & $58(1 \%)$ & $22(2 \%)$ & $16(1 \%)$ \\
\hline Not supplied & $961(22 \%)$ & $979(24 \%)$ & $264(20 \%)$ & $255(19 \%)$ \\
\hline \multicolumn{5}{|l|}{ Extent of resection } \\
\hline Complete & $4119(96 \%)$ & $3951(95 \%)$ & $1097(83 \%)$ & $1121(83 \%)$ \\
\hline Incomplete & $120(3 \%)$ & $123(3 \%)$ & $179(14 \%)$ & $186(14 \%)$ \\
\hline Unknown & $66(1 \%)$ & $68(2 \%)$ & $39(3 \%)$ & $38(3 \%)$ \\
\hline \multicolumn{5}{|l|}{ Radiotherapy timing } \\
\hline CT before RT & - & - & $941(72 \%)$ & $963(72 \%)$ \\
\hline Concomitant CT + RT & - & - & $374(28 \%)$ & $382(28 \%)$ \\
\hline
\end{tabular}

\section{A P P E N D I C E S}

\section{Appendix I. MEDLINE Search Strategy}

Cochrane Highly Sensitive Search Strategy for identifying RCTs (MEDLINE) (Lefebvre 2008)

1. "randomi*ed controlled trial".pt.

2. controlled clinical trial.pt.

3. "randomi*ed".ab.

4. placebo.ab.

5. drug therapy.fs.

6. randomly.ab.

7. trial.ab.

8. groups.ab.

9. 1 or 2 or 3 or 4 or 5 or 6 or 7 or 8

Adjuvant chemotherapy for resected early-stage non-small cell lung cancer (Review)

Copyright $\odot 2015$ The Cochrane Collaboration. Published by John Wiley \& Sons, Ltd. 
10. (animals not (humans and animals)).sh.

11. 9 not 10

Terms specific to lung cancer:

12. exp Lung Neoplasms/

13. exp Carcinoma, Non-Small-Cell Lung/

14. (lung $\$$ adj3 canc\$).mp.

15. (lung $\$$ adj3 carcinoma $\$$ ).mp.

16. (lung $\$$ adj3 tumo? $\$$ ).mp.

17. (lung $\$$ adj3 neoplasm $\$$ ).mp.

18. 12 or 13 or 14 or 15 or 16 or 17

Terms specific to the intervention:

19. exp Drug Therapy/

20. chemotherapy.mp.

21. 19 or 20

22. exp Radiotherapy/

23. radiotherapy.mp.

24. 22 or 23

25. exp General Surgery/

26. surgery.mp.

27. 25 or 26

28. 21 or 24 or 27

29. 11 and 18 and 28

\section{CONTRIBUTIONSOFAUTHORS}

NSCLC Meta-analysis Collaborative Group

Project Management Group (A Auperin, T Le Chevalier, C Le Pechoux, JP Pignon, H Tribodet (Institut Gustave-Roussy, Villejuif, France); S Burdett, LA Stewart, JF Tierney, RJ Stephens (MRC Clinical Trials Unit at UCL, London, UK).

International Advisory Group: R Arriagada (Karolinska Institutet, Stockholm, Sweden; Institut Gustave-Roussy, Villejuif, France); JP Higgins (MRC Biostatistics Unit, Cambridge, UK); DH Johnson (Vanderbilt-Ingram Cancer Center, Nashville, USA); J van Meerbeeck (University Hospital, Ghent, Belgium); MKB Parmar (MRC Clinical Trials Unit at UCL, London, UK); RL Souhami (Cancer Research UK, London, UK).

Writing group: (Project Management Group and International Advisory Group)

R Arriagada, A Auperin, S Burdett, JP Higgins, DH Johnson, T Le Chevalier, C Le Pechoux, MKB Parmar, JP Pignon, RL Souhami, RJ Stephens, LA Stewart, JF Tierney, H Tribodet, J van Meerbeeck.

Collaborators who supplied individual participant data (IPD): B Bergman, Salgrenska Academy, Gothenburg, Sweden (IALT); JY Douillard, Integrated Centers of Oncology R Gauducheau, St Herblain, France (ANITA); A Dunant, Institut Gustave-Roussy, Villejuif, France (IALT); C Endo, Institute of Development, Aging and Cancer, Tohoku University, Sendai, Japan (NJSGLCS); DJ Girling (Retired), MRC Clinical Trials Unit at UCL, London, UK (MRC LU02); H Kato, Tokyo Medical University, Tokyo, Japan (JLCSSG, JLCRG); SM Keller, Montefiore Medical Center, NY, USA (INT 0115); H Kimura, Chiba Cancer Center, Chiba City, Japan (IPCR CHIBA); A Knuuttila, Helsinki University Central Hospital, Helsinki, Finland (FLCSG1, FLCSG2); K Kodama, Osaka Medical Center for Cancer and Cardiovascular Diseases, Osaka, Japan (OLCSG1); R Komaki, University of Texas MD Anderson Cancer Center, Houston, TX, USA (MDA DM 87045); MG Kris, Memorial Sloan-Kettering Cancer Center, New York, NY, USA (MSKCC 8053); T Lad, Cook County Hospital, Chicago, IL, USA (LCSG 791, 801, 853); T Mineo, Policlinico Tor Vergata University, Rome, Italy (Mineo); S Piantadosi, Cedars Sinai Medical Centre, Samuel Oschin Comprehensive Cancer Inst, Los Angeles, CA, USA (LCSG 791, 801, 853); R Rosell, Catalan Institute of Oncology, Hospital Germans Trias i Pujol, Barcelona, Spain (ANITA); GV Scagliotti, S Luigi Hospital, Torino, Italy (ALPI); LW Seymour, Queen's University, NCIC Clinical Trials Group, Kingston, ON, Canada (JBR.10); FA Shepherd, Princess Margaret Hospital, Toronto, ON, Canada (JBR.10); SG Spiro, University College Hospital, London, UK (BLT); R Sylvester, EORTC Headquarters, Brussels, Belgium (EORTC 08861); HTada, Osaka City General Hospital, Osaka, Japan (JCOG 9304, OLCSG2); F Tanaka, Hyogo College of Medicine, Nishinomiya, Japan (WJSG2, WJSG3, WJSG4); V Torri, Istituto di Ricerche

Adjuvant chemotherapy for resected early-stage non-small cell lung cancer (Review)

Copyright @ 2015 The Cochrane Collaboration. Published by John Wiley \& Sons, Ltd. 
Farmacologiche "Mario Negri”, Milan, Italy (ALPI); D Waller, Glenfield Hospital, Groby Road, Leicester (BLT); GC Xu, Sun Yat-Sen University Cancer Center, Guangzhou, China (XU).

\section{DECLARATIONSOF INTEREST}

There is no known conflict of interest.

\section{SOURCES OF SUPPORT}

\section{Internal sources}

- Medical Research Council, UK.

- Institute Gustave Roussy, France.

\section{External sources}

- INSERM 921204, France.

- ARC 2025, France.

\section{NOT E S}

This review is an update of part of previous review, NSCLC Collaborative Group 2000. This review supercedes the previous review which will not be updated.

\section{NDEX TERMS}

\section{Medical Subject Headings (MeSH)}

Antineoplastic Agents [therapeutic use]; Carcinoma, Non-Small-Cell Lung [ ${ }^{*}$ drug therapy; mortality; pathology; radiotherapy; *surgery]; Chemotherapy, Adjuvant; Combined Modality Therapy [methods]; Lung Neoplasms [*drug therapy; mortality; pathology; radiotherapy; *surgery]; Randomized Controlled Trials as Topic; Tumor Burden

\section{MeSH check words}

Humans 